\title{
Luckey Roberts, Willie "the Lion" Smith, "Fats" Waller, and James P. Johnson: An Analysis of Historical, Cultural, and Performance Aspects of Stride Piano from 1910 to 1940
}

Jacob Womack

West Virginia University

Follow this and additional works at: https://researchrepository.wvu.edu/etd

\section{Recommended Citation}

Womack, Jacob, "Luckey Roberts, Willie "the Lion" Smith, "Fats" Waller, and James P. Johnson: An Analysis of Historical, Cultural, and Performance Aspects of Stride Piano from 1910 to 1940" (2013). Graduate Theses, Dissertations, and Problem Reports. 5012.

https://researchrepository.wvu.edu/etd/5012

This Dissertation is protected by copyright and/or related rights. It has been brought to you by the The Research Repository @ WVU with permission from the rights-holder(s). You are free to use this Dissertation in any way that is permitted by the copyright and related rights legislation that applies to your use. For other uses you must obtain permission from the rights-holder(s) directly, unless additional rights are indicated by a Creative Commons license in the record and/ or on the work itself. This Dissertation has been accepted for inclusion in WVU Graduate Theses, Dissertations, and Problem Reports collection by an authorized administrator of The Research Repository @ WVU.

For more information, please contact researchrepository@mail.wvu.edu. 
Luckey Roberts, Willie "the Lion" Smith, "Fats" Waller, and James P. Johnson: An Analysis of Historical, Cultural, and Performance Aspects of Stride Piano from 1910 to 1940.

\title{
Jacob Womack
}

\section{Research Document submitted to the College of Creative Arts at West Virginia University in partial fulfillment of the requirements for the degree of}
Doctor of Musical Arts in
Piano Performance

Peter Amstutz, D.M.A.

Mary Ferer, Ph.D.

Andrew Kohn, Ph.D.

James Miltenberger, D.M.A., Committee Chair and Research Advisor Bernie Schultz, Ph.D.

\author{
School of Music
}

Morgantown, West Virginia

2013

Keywords: Stride; Piano;

Luckey Roberts; James P. Johnson; Willie "the Lion" Smith; Thomas "Fats" Waller 


\section{ABSTRACT \\ Luckey Roberts, Willie "the Lion" Smith, "Fats" Waller, and James P. Johnson: An Analysis of Historical, Cultural, and Performance Aspects of Stride Piano from 1910 to 1940.}

\section{Jacob Womack}

Stride (Harlem piano) is a jazz piano style that flourished from c. 1910 to c. 1940 , primarily in New York. Revolving around the four most significant Harlem stride pianistcomposers, Luckey Roberts, James P. Johnson, Willie "the Lion" Smith, and Fats Waller, this research document focuses on the history, performance practices, and stylistic characteristics of the genre. Through an extensive study of relevant literature and analysis of select stride compositions and transcriptions including Luckey Roberts' Pork and Beans, James P. Johnson's The Mule Walk, Willie “the Lion" Smith's Cuttin' Out, and Fats Waller's Handful of Keys, this research document investigates the origin, competitive nature, dissemination, and musical traits of the genre. Furthermore, this study illuminates how the competitive nature of this genre led to the development of the first virtuosic jazz piano style - stride. 


\section{ACKNOWLEDGEMENTS}

There are several people I would like to thank for their guidance and support while completing this project. First, I would like to thank my research advisor, Dr. James Miltenberger, for his wisdom and many hours spent helping me over the past year. I would like to express my appreciation to Dr. Peter Amstutz, Dr. Mary Ferer, Dr. Andrew Kohn, and Dr. Bernie Schultz for time they devoted as members of my committee. Finally, I would like to thank Sheila Barnhart for her patience, love, support, and many hours in helping me put together this paper. 


\section{CONTENTS}

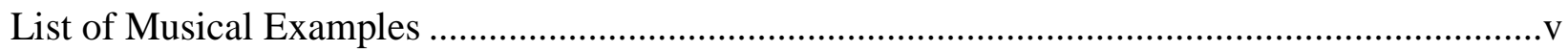

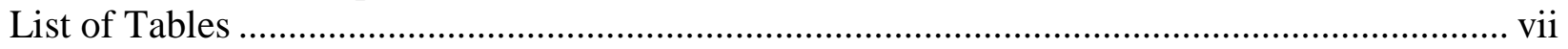

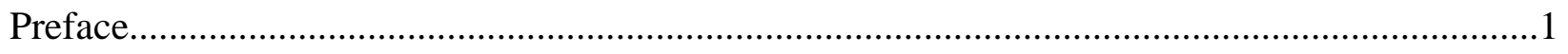

Chapter 1: The Origins and Socio-Cultural Aspects of Stride ...............................................5

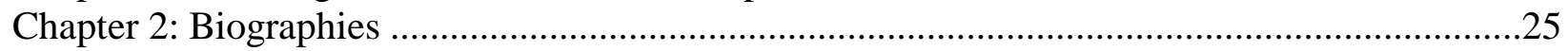

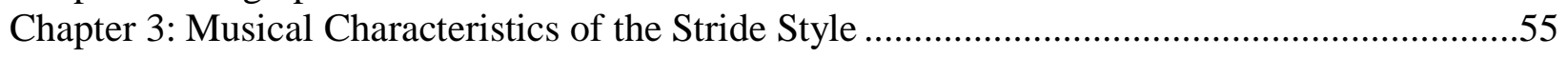

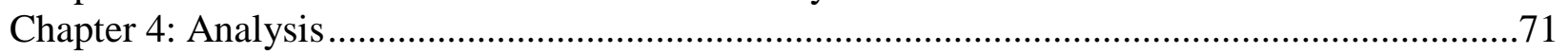

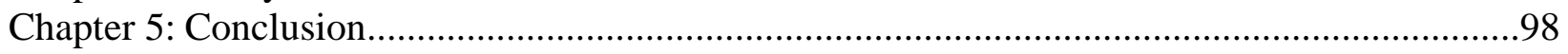

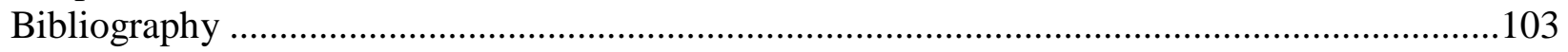




\section{LIST OF MUSICAL EXAMPLES}

Example 3.1: Call-and-Response in James P. Johnson's 1944 Recording of Carolina Shout (mm. 54-57).Transcription by Riccardo Scivales ...............................................57

Example 3.2: Complex Syncopation in Fats Waller's 1929 Recording of Handful of Keys (mm. 81-83).Transcription by Paul Posnak

Example 3.3: Off-beat Melody in James P. Johnson's 1944 Recording of Carolina Shout (mm. 23-25).Transcription by Riccardo Scivales .................................................58

Example 3.4: “Crush” Tones in James P. Johnson's 1944 Recording of Carolina Shout (mm. 63-64). Transcription by Riccardo Scivales

Example 3.5: "Omm-pah" in James P. Johnson's 1939 Recording of The Mule Walk (mm. 3-4) for Columbia Records. Transcription by Riccardo Scivales.

Example 3.6: Tenths Used on Strong Beats During an “Omm-pah” in Fats Waller's 1929 Recording of Smashing Thirds (mm. 54-57) .Transcription by Paul Posnak .........62

Example 3.7a: Compact “Omm-pah” in Scott Joplin's Maple Leaf Rag (mm. 17-20) .

Example 3.7b: "Omm-pah" with Wide Leaps in James P. Johnson's 1939 Recording of The Mule Walk (mm. 7-10). Transcription by Riccardo Scivales.

Example 3.8: Reversed “Omm-pah” in James P. Johnson's 1944 Recording of Carolina Shout (mm. 6-9). Transcription by Riccardo Scivales .64

Example 3.9: Backward Tenths in Fats Waller's 1929 Recording of Gladyse (mm. 77-78).

Transcription by Paul Posnak .64

Example 3.10: Walking Bass Line in Fats Waller's 1929 Recording of Valentine Stomp (mm. 133-135).Transcription by Paul Posnak ....

Example 3.11: Boogie-Woogie Bass Line in Waller's 1929 Recording of Numb Fumblin'. (mm. 53-54). Transcription by Paul Posnak

Example 3.12: Tango Rhythm (left hand) in James P. Johnson's 1944 Recording of Carolina Shout (mm. 150-151). Transcription by Riccardo Scivales .66

Example 3.13a: A Riff in James P. Johnson's 1944 Recording of Carolina Shout (mm. 6-9). Transcription by Riccardo Scivales

Example 3.13b: Johnson's Riff Varied (mm. 22-25)....

Example 3.14: A Groove in James P. Johnson's 1944 Recording of Carolina Shout (mm. 86-90).

Transcription by Riccardo Scivales .68

Example 3.15: Extended Harmony (added ninth) in Fats Waller's 1929 Recording of Handful of Keys (m. 104). Transcription by Paul Posnak. .70

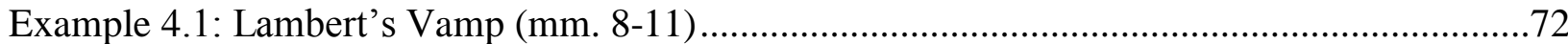

Example 4.2a: Pork and Beans "A” Strain Riffs (mm. 11-19)...............................................73

Example 4.2b: Pork and Beans "C" Strain Riffs (mm. 59-67) ....................................................73

Example 4.3a: Pork and Beans "B”" Strain Groove (mm. 27-35) ...........................................74

Example 4.3b: Pork and Beans "D” Strain Groove (mm. 75-82) .........................................75

Example 4.4: Pork and Beans Anticipatory Melody (mm. 11-12) ..........................................75

Example 4.5: Pork and Beans Syncopated Melody (mm. 55-58) ..........................................75

Example 4.6: Pork and Beans Walking Bass Line (mm. 35-36) .............................................76

Example 4.7: Pork and Beans Repeated Chord Voicings (mm. 23-26) ....................................76

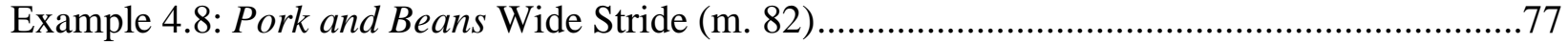

Example 4.9: Pork and Beans Call-and-Response (mm. 27-30) ................................................77 


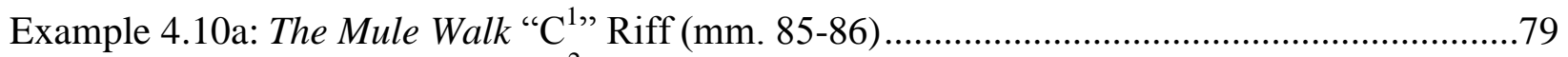

Example 4.10b: The Mule Walk " $\mathrm{C}^{2, "}$ Riff, Rhythmic Variation (mm. 101-102)..........................79

Example 4.11: The Mule Walk Wide Stride (mm. 7-10) ............................................................8

Example 4.12: The Mule Walk Walking Bass Line (mm. 98-99) ……..........................................80

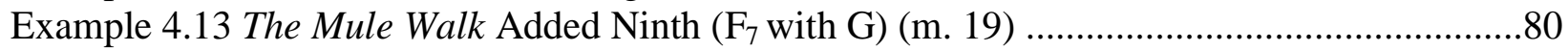

Example 4.14: The Mule Walk Lowered Third in B-flat Chord (m. 4) .......................................81

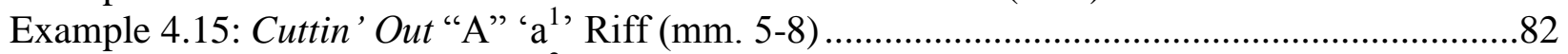

Example 4.16: Cuttin' Out "A" 'a ", Riff, Rhythmic Variation (mm. 61-64) ...............................83

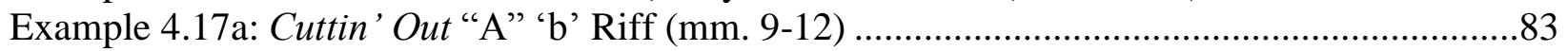

Example 4.17b: Cuttin' Out "A” 'b' Riff, Melody Altered (mm. 25-28)......................................83

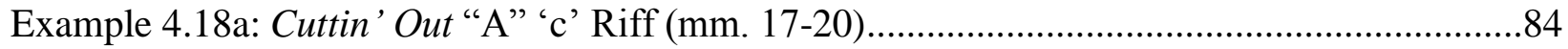

Example 4.18b: Cuttin' Out "A” 'c' Riff, Melody Altered (mm. 33-36) …………….....................84

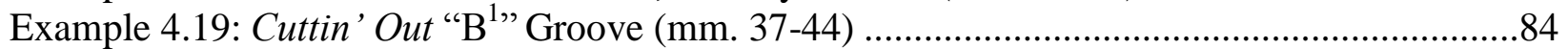

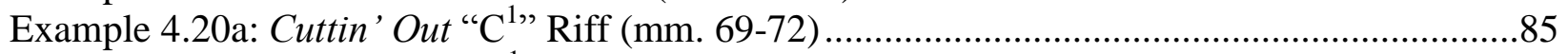

Example 4.20b: Cuttin' Out "C $\mathrm{C}$ "” Riff, Melodic and Rhythmic Alteration (mm. 77-80)...............85

Example 4.21a: Cuttin' Out "D” Riff (mm. 101-104) ...............................................................

Example 4.21b: Cuttin' Out "D" Riff, Rhythmic and Chordal Variation (mm. 117-120) .............85

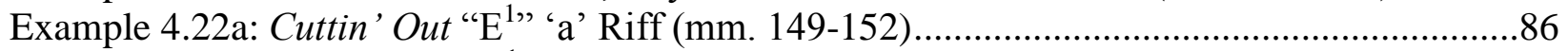

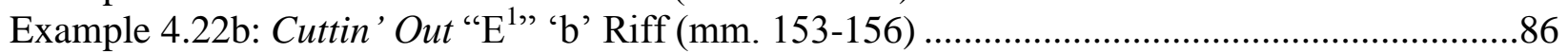

Example 4.23: Cuttin' Out Compact “Omm-pah"(mm. 21-22) …………………........................86

Example 4.24: Cuttin' Out Walking Bass Line (mm. 34-35) .....................................................87

Example 4.25: Cuttin' Out Tango Rhythm (left hand) (m. 138) ....................................................

Example 4.26: Cuttin' Out Off-Beat Melody (mm. 60-64) ............................................................8

Example 4.27: Cuttin' Out Complex Syncopation (mm. 179-182) ................................................8

Example 4.28a: Handful of Keys " $\mathrm{A}$ "” (X) Riff (m. 9-10) .............................................................

Example 4.28b: Handful of Keys " $\mathrm{A}$ "”, (X) Riff,

8va Added and New Accompaniment (mm. 41-42) ..........................................91

Example 4.29a: Handful of Keys " $\mathrm{A}$ "” (Y) Riff (mm. 25-26) .......................................................92

Example 4.29b: Handful of Keys " $A$ "," (Y) Riff, New Rhythm (mm. 157-158) .............................92

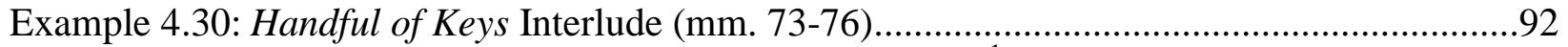

Example 4.31: Handful of Keys Trick (chordal passage) in "B" " (mm. 96-100)..........................93

Example 4.32: Handful of Keys Trick (alternating octaves) in " $\mathrm{B}$ " (mm. 88-92) .........................94

Example 4.33: Handful of Keys Fast Harmonic Rhythm (m. 94) ...............................................94

Example 4.34: Handful of Keys

Extended Harmony (added ninth on the $\mathrm{G}^{7}$ chord) (m. 104) .................................94

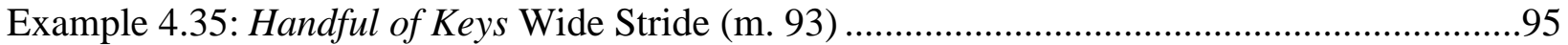

Example 4.36: Handful of Keys Walking Bass Line (mm. 137-140) ..........................................95

Example 4.37: Handful of Keys Tenths (m. 97)........................................................................95

Example 4.38: Handful of Keys Call-and-Response (mm. 9-10)..................................................96 


\section{LIST OF TABLES}

Table 3.1: Typical Twelve-Bar Blues Chordal Progression ...................................................59

Table 3.2: Strain Arrangements and Harmonic Schemes .....................................................61

Table 4.1: Thematic Presentation in Lambert's 1961 Recording of Pork and Beans ..................72

Table 4.2: Thematic Presentation in Johnson's 1939 Recording of The Mule Walk ....................79

Table 4.3: Thematic Presentation in Willie "the Lion" Smith's 1949 Recording of Cuttin' Out..82

Table 4.4: Thematic Presentation in Fats Waller's 1929 Recording of Handful of Keys..............89

Table 4.5: Phrase Structure of Handful of Keys..........................................................................90 


\section{PREFACE}

Introduction and Intent

Stride piano, also known as Harlem piano, is one of the oldest and most technically demanding of jazz piano styles. ${ }^{1}$ This idiom, primarily a New York phenomenon, emerged around 1910 and peaked in popularity during the mid-1920s. However, several other cities in the northeast, particularly Atlantic City, also harbored the growth of the stride idiom. ${ }^{2}$

Stride is a synthesis of three African-American musical genres: ragtime, the blues, and the ring shout. ${ }^{3}$ The most influential of these was ragtime. Piano rolls and recordings from the early 1920s demonstrate that stride pianists used ragtime's left hand accompanimental patterns and multi-sectional forms as a basis for composing tunes. ${ }^{4}$

The left hand is king in stride. Stride performers developed virtuosic left hands capable of playing “omm-pah” accompaniment patterns with large leaps, extended passages of tenths, and complicated bass lines, all of which are usually played at fast tempos. ${ }^{5}$ Additionally, the best stride performers could improvise countermelodies in the left hand. ${ }^{6}$

James P. Johnson described stride as an orchestral style of piano playing - a large sound generated by the use of big chords, tenths, full range of the instrument, and a heavy bass line that tugged against the melody. ${ }^{7}$ Johnson provides the following explanation as to why the orchestral style of playing emerged.

\footnotetext{
${ }^{1}$ Riccardo Scivales, Harlem Stride Piano Solos: 26 Classic Solos by The Greatest Jazz Pianists of The Swing Era (Bedford Hills, NY: Ekay Music, 1995), 6.

${ }_{2}^{2}$ Alyn Shipton, A New History of Jazz (New York: Continuum, 2007), 127.

${ }^{3}$ Ibid., 128.

${ }^{4}$ Henry Martin, "Pianists of the 1920s and 1930s," in The Oxford Companion to Jazz, ed. Bill Kirchner (New York: Oxford University Press, 2000), 165.

${ }^{5}$ The "Omm-pah" and other left hand stride devices are discussed in detail in chapter three.

${ }^{6}$ J. Bradford Robinson, "Stride." In Grove Music Online. Oxford Music Online (accessed March 10, 2012), <http://www.oxfordmusiconline.com/subscriber/article/grove/music/26955>

${ }^{7}$ Tom Davin, "Conversations with James. P. Johnson," in Ragtime: Its History, Composers, and Music, ed. John Edward Hasse (New York: Schirmer, 1985), 170.
} 
The people in New York were used to hearing good piano played in concerts and cafés. The ragtime player had to live up to that standard. They had to go get orchestral effects, sound harmonies, chords and all the technique of European concert pianists who were playing their music all over the city. ${ }^{8}$

Modern stride pianist Henry A. Francis defines the stride style as:

A truly solo idiom; it is entirely self-sufficient and requires no rhythmic or harmonic assistance. In fact, the addition of rhythm instruments usually obscures the impish strut of solo stride piano. The style generates a very full, orchestral sound, as the oscillating left hand activates simultaneously both the low and middle registers, while the right hand operates in the upper registers. $^{9}$

There are a multitude of other Harlem pianists who contributed to the development of the stride idiom. Some of the earliest stride pioneers include Jack "the Bear" Wilson, Willie Gant, Fred Tunstall, Willie Joseph, Bob Hawkins, Richard McClean (better known as Abba Labba), Alberta Simmons, and Corky Williams. ${ }^{10}$ A handful of talented pianists, such as Art Tatum and Ralph Sutton, continued playing stride well into the be-bop and modern jazz eras. ${ }^{11}$

This research project is an exploration of stride from c. 1910 to c. 1940, examining the history, performance practices, and stylistic characteristics of the genre. This project fills a gap in the literature concerning stride in several ways. First, it provides more in-depth information about the socio-cultural aspects of stride, a subject which is often only mentioned in passing in other literature. Second, it addresses the musical and technical aspects of stride in more detail than in previous studies. Finally, it contains analysis of four compositions/performances which have not been scholastically researched. Revolving around the four most significant Harlem stride pianist-composers, Luckey Roberts, James P. Johnson, Willie "the Lion” Smith, and Fats Waller, the document is divided into five chapters.

${ }^{8}$ Ibid., 170.

${ }^{9}$ Henry A. Francis, "Musical Attributes of Fats Waller the Pianist," in Fats in Fact, ed. Laurie Wright (Chigwell: Storyville, 1992) in A New History of Jazz, Alyn Shipton (New York: Continuum, 2007), 127.

${ }^{10}$ Thomas L. Riis, "New York Roots: Black Broadway, James Reese Europe, Early Pianists," in The Oxford Companion to Jazz, ed. Bill Kirchner (New York: Oxford University Press, 2000), 61.

${ }^{11}$ Robinson. 
Chapter one is an examination of the social and cultural forces behind stride. First, an overview of ragtime's history is presented, including information about its origins, where it flourished, and how its demise paved the way for stride. Second, the nightlife and clubs in three predominantly black Manhattan neighborhoods where stride thrived: the "Tenderloin," "San Juan Hill," and "Harlem" are explored. Third, Harlem rent parties, social events where stride pianists provided entertainment, are discussed. Fourth, the competitive nature of stride performers is examined, including an overview of cutting contests - musical competitions where stride pianists developed their reputations and gained bragging rights. Fifth, performance and technical skills associated with stride are explored. Sixth, information on non-musical aspects associated with stride performances is discussed, including details on how stride pianists talked, dressed, and walked. Finally, an overview of the dissemination of stride is presented.

Chapter two contains biographical information for Roberts, Johnson, Smith, and Waller. Their musical training, careers as musicians, and significant compositions, recordings, and performances are explored.

Chapter three is an examination of the musical aspects of stride. In this chapter the influence of dance music, the ring shout, the blues, and ragtime on stride is discussed. Additionally, harmonic elements, formal conventions, rhythmic features, use of call-andresponse devices, left hand accompanimental patterns, right hand melodic patterns, and performance considerations, such as improvisation and pedaling, are explored.

In chapter four, transcriptions of four recordings including Donald Lambert's 1961 performance of Luckey Roberts' Pork and Beans, James P. Johnson's 1939 recording of The Mule Walk, Willie “the Lion" Smith's 1949 recording of Cuttin' Out, and Fats Waller's1929 
recording of Handful of Keys, are examined by applying the musical elements discussed in chapter three.

In chapter five conclusions are presented.

The following terms will be discussed in this document:

1) Boogie-Woogie: A style of solo piano in which the left hand plays a repeated bass pattern of single notes, usually one- to two-measures.

2) Groove: A short thematic idea that is repeated continuously with no alteration to the rhythm or pitches.

3) Omm-pah: A regular alternation of low bass notes or octaves on strong beats and mid-range chords on weak beats

4) Riff: A two- or four-bar thematic idea that undergoes some sort of alteration as a strain progresses. Either the pitch content is preserved while the rhythm is modified, or the pitch content is modified and the rhythm is preserved.

5) Strain: A section within a musical composition that contains several phrases of similar thematic content. In ragtime and stride, strains are usually sixteen bars in length.

6) Stride: The distance between the strong and weak beats in the "omm-pah." 


\section{Chapter One}

The Origins and Socio-Cultural Aspects of Stride

Stride emerged in New York during the early 1910s and peaked in popularity during the 1920s. The audience for stride was largely southern blacks from the Carolinas and Georgia who had migrated to New York in search of a better way of life. Since stride is principally derived from ragtime, this chapter begins with an overview of ragtime's history. The remainder of the chapter is an examination of how the entertainment interests of New York's black population and competitive spirit of Harlem pianists stimulated the development of stride.

Ragtime is primarily a piano compositional and performance style that flourished from c. 1895 to c. 1920 . Popular ragtime songs were often arranged and transcribed for band or orchestra. Ragtime's moderate tempo and rhythmic energy made it suitable for dances such as the cakewalk and two-step. Three of the most well-known ragtime composers are Scott Joplin, James Scott, and Joseph Lamb. ${ }^{12}$

The origin of ragtime is obscure. Some jazz scholars believe that southern AfricanAmerican pianists started playing in a "ragged" style as far back as the early 1880s. Due to a lack of physical evidence, such as sheet-music or recordings, this theory cannot be verified. Most jazz scholars refer to the 1893 World's Columbian Exposition in Chicago as the beginning of ragtime. ${ }^{13}$ Nearly a dozen African-American ragtime pioneers, including Ben Harney and Scott Joplin, attended the six-month Exposition. These pianists played at nearby taverns and saloons where many of the Exposition's nearly 20 million attendees heard ragtime for the first time. The event helped create a ragtime craze. ${ }^{14}$

\footnotetext{
${ }^{12}$ Edward A. Berlin, "Ragtime." In Grove Music Online. Oxford Music Online (accessed March 7, 2012), <http://www.oxfordmusiconline.com/subscriber/article/grove/music/22825>

${ }^{13}$ Burton W. Peretti, Jazz in American Culture (Chicago: Ivan R. Dee, 1997), 11-12.

14 Berlin, "Ragtime."
} 
Defining musical features of ragtime include a march beat, left hand "omm-pah",15 accompaniment, standard chord progressions, and syncopated melodies. ${ }^{16}$ Ragtime was usually performed slowly, whereas stride was often played quickly. Scott Joplin often left indications such as "Slow March Tempo" or "Notice! Don’t play this piece fast. It is never right to play 'Ragtime' fast,' in his published scores. ${ }^{17}$ Ragtime music differs from most styles of jazz in that the music was usually written out in its entirety. Only a few ragtime pianists could improvise a rag on a popular tune. ${ }^{18}$

Missouri railroad hubs, such as St. Louis, Sedalia, and Carthage, were major centers of ragtime during the late nineteenth and early twentieth centuries. These communities had an abundance of clubs and nightlife, which often featured a ragtime pianist to entertain railroad travelers passing through. The most well-known Missourian ragtime composer and pianist was Scott Joplin. He published the majority of his popular ragtime tunes, such as Maple Leaf Rag and The Entertainer, while living in Missouri from 1894 to $1907 .{ }^{19}$

A second significant locale where ragtime thrived was New York. Ben Harney is credited for bringing the ragtime style to New York in $1896 .{ }^{20}$ By the early 1900 s nearly every tavern and saloon in Manhattan featured an African-American pianist performing Tin Pan Alley pop tunes in the ragtime style. Scott Joplin moved to New York in $1907 .{ }^{21}$ Interestingly, even though Joplin

\footnotetext{
${ }^{15}$ For an explanation of “omm-pah" see pages $58-60$.

${ }^{16}$ Peretti, 13.

${ }^{17}$ Rudi Blesh and Harriet Janis, They All Played Ragtime: The True Story of an American Music (New York: Alfred A. Knopf, 1950), 190.

${ }^{18}$ Gerald S. Alioso, "A Historical Summary of Major Musical Developments in American Jazz from the end of World War I to the Beginning of World War II," (DMA diss., University of Cincinnati, 1995$), 20$.

19 Ted Gioia, ed., The History of Jazz (New York: Oxford University Press, 1997), 23.

${ }^{20}$ Edward Berlin, Reflections and Research on Ragtime (Brooklyn: Institute for Studies in American Music, 1987), 37.

${ }^{21}$ Peretti, 12-17.
} 
was a nationally recognized ragtime composer and performer, none of the major stride pianists, such as Roberts and Johnson, sought him out. ${ }^{22}$

The height of ragtime occurred during the early 1910s. This was largely due to the popularity of ragtime dancers Vernon and Irene Castle and ragtime musician James Reese Europe. However, the novelty of ragtime rapidly faded away during the second half of the 1910s as American popular listening tastes shifted towards faster and more socially daring music.

Stride was one response to this change in musical tastes. Stride performers kept the core musical elements of ragtime, ${ }^{23}$ particularly the formal principles and accompanimental patterns.

However, unlike the relaxed nature of ragtime, stride musicians played their music with flamboyancy and at considerably faster tempos. ${ }^{24}$ The audience for stride was primarily southern black migrants who had recently relocated to New York.

For nearly a century (c.1890-1970) African-Americans migrated from the rural south to cities in the mid-west, north, and west, hoping to find work and better living conditions. Blacks encountered discrimination, faced violence from whites, and lived in extreme poverty while living in the south. ${ }^{25}$ A large number of blacks moved to one particular northern city, New York. Most southern African-Americans that relocated to New York around 1900 settled in mid-town Manhattan. During the next two decades Manhattan's black population gradually shifted uptown towards Harlem. ${ }^{26}$

The "Tenderloin," an area of Manhattan stretching from 23rd Street to 42nd Street and between Fifth Avenue to Seventh Avenue, had the largest African-American population during the first decade of the twentieth century, though never developing into an all-black community.

\footnotetext{
${ }^{22}$ Berlin, Reflections and Research on Ragtime, 78.

${ }^{23}$ The musical elements of stride are discussed in chapter three.

${ }^{24}$ Martin, "Pianists of the 1920s and 1930s," 163-168.

25 Peretti, 15.

${ }^{26}$ Gioia, 94-95.
} 
Many of the stride pioneers visited saloons, theaters, restaurants, gambling houses, and brothels in the "Tenderloin" where premier east-coast ragtime pianists performed. In fact, James P. Johnson's biographer Scott E. Brown cites specific occasions when Johnson visited brothels along 27 th Street to hear ragtime played. ${ }^{27}$

The most famous night-spot in the "Tenderloin" was Barron Wilkins" "Little Savoy Club," located on 32nd Street. This club featured a number of renowned ragtime pianists including “One-leg” Willie Joseph (greatly admired by Eubie Blake) and Luckey Roberts. Barron Wilkins relocated his club to 35th Street around 1910 and to Harlem in $1914 .^{28}$

By 1910 a significant portion of Manhattan's African-American population had migrated uptown nearly twenty blocks to an area of town that had a variety of nicknames, including "San Juan Hill," “The Jungles," and "Hell's Kitchen.” This neighborhood lay west of Columbus Avenue (Ninth Avenue), stretching from 60th Street to 64th Street. ${ }^{29}$ Due to its gangs, fights, and nightly killings, "San Juan Hill” developed a reputation as the most dangerous area of Manhattan. ${ }^{30}$ Although "San Juan Hill” lacked ambiance it provided a rich culture for the development of stride. ${ }^{31}$

Notable all-black clubs located in "San Juan Hill” included Phil Watkin's and Jim Allan's on 61 st Street and Georgia Lee's on 62nd Street. ${ }^{32}$ However, "Drake's Dancing Class," known by the locals as "The Jungles Casino," was the most popular venue in "San Juan Hill." Located on 62nd Street, “The Jungles Casino" featured some of the most talented stride pianists

\footnotetext{
${ }^{27}$ Berlin, Reflections and Research on Ragtime, 45-57.

${ }^{28}$ Edward Berlin, "Ragtime in Old New York," NYC Jazz (June 1980): 22.

${ }^{29}$ Berlin, Reflections and Research on Ragtime, 45-58.

${ }^{30}$ Davin, 173.

${ }^{31}$ Berlin, Reflections and Research on Ragtime, 58.

${ }^{32}$ Berlin, "Ragtime in Old New York," 22.
} 
including James P. Johnson, Luckey Roberts, Abba Labba, and Willie "the Lion" Smith. ${ }^{33}$ James P. Johnson provides the following description of "The Jungles Casino:"

It was officially a dancing school, since it was very hard for Negros to get a dance-hall license. But you could get a license to open a dancing school very cheap... There were dancing classes all right, but there were no teachers. The "pupils" danced sets, two-steps, waltzes, schottisches, and "The Metropolitan Glide," a new step.

I played for these regulation dances, but instead of playing straight, I'd break into a rag in certain places. The older ones didn't care too much for this, but the younger ones would scream when I got good to them with a bit of rag in the dance music now and then. ${ }^{34}$

The dances they did at the Jungles Casino were wild and comical - the more pose and the more breaks the better. These Charleston people and the other southerners had just come to New York. They were country people and they felt homesick. When they got tired of two-steps and schottisches (which they dance with a lot of spieling), they'd yell: "Let's go back home!" . . or "Now put us in the alley!" I did my "Mule Walk" or "Gut Stomp" for these country dances. Breakdown music was the best for such sets, the more solid and groovy the better. They'd dance, hollering and screaming until they were cooked. The dances ran from fifteen to thirty minutes, but they kept up all night until their shoes wore out - most of them after a heavys day's work on the docks. ${ }^{35}$

Prior to 1905, Harlem's population primarily consisted of middle-class whites. However, Harlem underwent a major demographic change from 1905 to $1920 .{ }^{36}$ By the late 1910s Harlem was the Manhattan neighborhood with the largest African-American population. Located on the northern tip of Manhattan, Harlem's boundaries stretched from 110th Street to 155th Street and from the Harlem River to St. Nicholas Avenue. ${ }^{37}$ A number of factors caused this population shift.

White realtors severely overestimated the potential housing market in Harlem during the early 1900s. With apartments and houses sitting empty property values plummeted. A few black entrepreneurs saw a perfect business opportunity to capitalize on Harlem's real-estate crash by

\footnotetext{
${ }^{33}$ Berlin, Reflections and Research on Ragtime, 58-59.

${ }^{34}$ Davin, 173.

${ }^{35}$ Bruce Barnhart, "CAROLINA SHOUT: James P. Johnson and the Performance of Temporality,"

${ }^{36}$ Gioia, 94-95.

${ }^{37}$ Berlin, Reflections and Research on Ragtime, 70.
} Callaloo (Summer 2010): 841. 
filling vacant living spaces in Harlem with the influx of African-Americans migrating from the south. $^{38}$

Around 1905, these black entrepreneurs started renting apartments to African-Americans on 133rd and 134th streets between Lenox and Seventh avenues. Middle-class whites living in houses that bordered this new black section of Harlem panicked and started moving to other parts of the city. This opened up new property for African-American businessmen to purchase and rent out. By 1910 African-American realtors controlled a large section of Harlem that stretched from 122nd Street to 127th Street and from 133rd Street to 136th Street. ${ }^{39}$ The cycle of whites leaving Harlem and black entrepreneurs acquiring the vacated housing continued into the late 1920s, and between 1910 and 1920 the black population of this segregated community grew by sixty-six percent. ${ }^{40}$

With Harlem's African-American population segregated to the middle section of the neighborhood, the majority of the all-black clubs opened in this vicinity. ${ }^{41}$ In 1910 Barron Wilkins' older brother, Leroy, opened up the first Harlem black cabaret of any significance on the corner of 135th Street and Fifth Avenue. Leroy's place had a different atmosphere than most cabarets. First, Leroy established a strict dress code for his cabaret, requiring floor managers, waiters, musicians, and customers to wear formal attire. Most other cabarets had no dress code. Second, the clientele consisted mostly of Harlem's elite African-Americans. Harlem cabarets were usually tailored the neighborhood's lower and middle-class population. Finally, unlike most

\footnotetext{
${ }^{38}$ Gioia, 94-95.

${ }^{39}$ Berlin, Reflections and Research on Ragtime, 70.

${ }^{40}$ Terkild Vinding and John L. Fell, Stride! Fats, Jimmy, Lion, Lamb, and all the other Ticklers (Lanham, MD: Scarecrow Press, 1999), 62-63.

${ }^{41}$ Shipton, 129-130.
} 
cabarets, Leroy's had no bar. People generate lots of noise around bars. The musicians

performing at Leroy's appreciated the quieter setting. ${ }^{42}$

Leroy Wilkins hired Smith as the house pianist during the early 1910s. A few other lucky stride pianists landed full-time playing jobs at premier Harlem clubs. Club owners only hired pianists that could generate large crowds. The salary for club pianists was small, usually twenty dollars a week. (Pianists carefully watched the tip jar making sure nobody stole from it.) In addition to performing as a soloist, club pianists had other duties and responsibilities such as accompanying singers, directing whatever band was on hand, and distributing tips among all performers, servers, and bartenders. ${ }^{43}$ In his autobiography Willie "the Lion" Smith asserts:

The bosses expected you to stay rooted to your stool from nine at night to dawn. Man, if you got up to go to the men's room those guys would scream. [The club owner] would come up wailing, "What are you trying to do, put me out of business?" And in those days you worked seven nights a week.

Furthermore, you'd rather piss in your pants than leave the piano when a rival was in the house. That was the best way to lose your gig. ${ }^{44}$

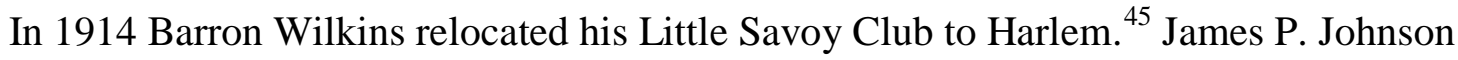
spoke highly of Barron Wilkins Harlem location, asserting that it "was the best known place of its kind in the country. Celebrities came to it from everywhere... The establishment had an orchestra of two pieces, piano and drum, and both men and girl entertainers." ${ }^{46}$ While most Harlem venues in the mid-1910s, such as Leroy Wilkins, excluded white patrons, Barron Wilkins admitted whites into his club. ${ }^{47}$ During the next decade a large number of Harlem club owners followed in Barron Wilkins footsteps, allowing whites to visit their venues. Eventually, Harlem

${ }^{42}$ Berlin, Reflections and Research on Ragtime, 71-74.

${ }^{43}$ Willie "the Lion" Smith, "Willie 'the Lion' Smith," in Reading Jazz: A Gathering of Autobiography, Reportage and Criticism from 1919 to Now, ed. Robert Gottlieb (New York: Pantheon, 1996), 28-29.

${ }^{44}$ Ibid., 28-29.

45 Berlin, "Ragtime in Old New York," 22.

${ }^{46}$ Berlin, Reflections and Research on Ragtime, 76.

${ }^{47}$ Ibid., 74. 
clubs, such as "Garden of Joy," that had at one time only admitted blacks started excluding them altogether. $^{48}$

A few other Harlem venues where stride pianists found employment included "The Rock" (or "Garden of Joy") on 140th Street, "Livia's" on 139th Street, “101 Ranch" on 139th Street, "Elk's Café" on 137th Street, “Jerry Preston's” on 135th Street, “The Orient” (Smith played there on occasion) on 135th Street, "Lincoln Theater" (Waller played organ for silent films here from 1917 to 1921) on 135th Street, "Pod's and Jerry's" (known by the locals as the “Catagonia Club") on 133rd Street, "Bert Hall's Rhythm Club” at the corner of 132nd Street and Seventh Avenue, and "The Band Box" on 131st Street. ${ }^{49}$ However, the most important setting that fostered the development of stride was the Harlem rent party. ${ }^{50}$

African-Americans enjoyed more freedom in New York than while living in the South. ${ }^{51}$ However, Harlem blacks faced many problems, including poor-paying jobs, a variety of health concerns, and, most pressing, inflated rent. ${ }^{52}$ African-American tenants paid significantly higher rent than white city dwellers. In some cases, landlords charged blacks twice as much in rent as what whites paid in other parts of the city. ${ }^{53}$

Harlem blacks devised a number of ways to manage the high rent. One strategy involved sharing an apartment with upwards of two or three times the intended number of inhabitants. This helped significantly reduce lodging costs. However, this tactic came at a price - crammed living space. In many instances up to five people ended up sharing one small bedroom, which often had space for only one or two mattresses. To ensure that everybody had a bed to rest on,

\footnotetext{
${ }^{48}$ Shipton, 130.

${ }^{49}$ Berlin, "Ragtime in Old New York," 22.

${ }^{50}$ Gioia, 95-96.

51 Ibid., 94-95.

52 Vinding and Fell, 63.

${ }^{53}$ Gioia, 94-95.
} 
African-Americans developed a rotational sleeping pattern known as "hot beds." Under this strategy roommates coordinated their schedules so that while one or two people worked the others slept. In some cases a bed would be occupied day and night. ${ }^{54}$

A second, and more creative, response to the financial demands of Harlem black realtors was a fund raising event called a "rent party." These social events had a variety of names including "parlor social" and "chitlin' strut." ${ }^{, 55}$ Admission to rent parties ranged from twenty-five cents to a dollar. The host(s) of the party applied the raised money towards the cost of the event and rent for the next month. ${ }^{56}$

According to jazz scholar Bruce Barnhart, "The dynamics and atmosphere [of rent parties lay] somewhere between those of the cabaret and those of the extended family gathering." ${ }^{, 57}$ As many as a hundred people might cram into an apartment for a rent party. ${ }^{58}$ These events included music, dancing, food, drinks, and the prospect of sexual interaction ${ }^{59}$ Rent parties occurred in a number of largely populated cities. However, the most extravagant rent parties took place in New York. ${ }^{60}$

Hosting a rent party often required planning for a month in advance. ${ }^{61}$ Two important components in organizing a rent party included booking a caterer and finding a pianist. Additionally, the host had to heavily promote his event in order to get patrons, since often more than one rent party took place on a given night. Hosts placed advertisements and circulars throughout neighborhoods and in individual mail boxes that detailed the time, place, food, and

\footnotetext{
${ }^{54}$ Vinding and Fell, 62.

${ }^{55}$ David A. Jasen and Gene Jones, Black Bottom Stomp: Eight Masters of Ragtime and Early Jazz (New

${ }^{56}$ Gioia, $94-95$.

${ }^{57}$ Barnhart, 849-850.

${ }^{58}$ Gioia, 94-95.

${ }^{59}$ Barnhart, 850 .

${ }^{60}$ Shipton, 130.

${ }^{61}$ Gioia, 94-95.
} York: Routledge, 2002), 70. 
pianist. ${ }^{62}$ One such invitation read: "If you're looking for a good time, don't look no more, just ring my bell, and I'll answer the door. Southern barbeque given by Charlie Johnson and Joe Hotboy, and How Hot!"63

The financial success of a rent party depended heavily on the pianist, the lone entertainer at these events. Finding a quality pianist with a good reputation helped to attract patrons for a party. ${ }^{64}$ Hosts often went to Raymond "Lippy" Boyette, an unofficial agent, to help them find the best available pianist. ${ }^{65}$ Some of the pianists that always generated good crowds included James P. Johnson, Willie "the Lion" Smith, and Fats Waller. ${ }^{66}$ The most in-demand rent-party pianists sometimes played as many as three events in one night. This required them to perform from the afternoon, through the night, and into the next day. ${ }^{67}$ Rent party pianists did not make a lot of money, often only $\$ 1.50$ per event. ${ }^{68}$ However, they earned social prestige and received free food and drinks at parties. ${ }^{69}$ In fact, the best pianists often went several days without buying a meal. ${ }^{70}$

Often various pianists showed up unannounced at rent parties and Harlem clubs to challenge the booked entertainer. ${ }^{71}$ Known as "cutting contests," such challenges played an important part in the development of stride. ${ }^{72}$ Cutting contests took place in many locales throughout the country, but the greatest occurred in New York. ${ }^{73}$

\footnotetext{
${ }^{62}$ Vinding and Fell, 65.

${ }^{63}$ New York Herald Tribune, 12 February 1930.

${ }^{64}$ Barnhart, 850.

${ }^{65}$ Vinding and Fell, 65.

${ }^{66}$ Gioia, 98.

${ }^{67}$ Barnhart, 850.

${ }^{68}$ Jasen and Jones, 70.

${ }^{69}$ Barnhart, 850.

${ }^{70}$ Jasen and Jones, 70.

${ }^{71}$ Vinding and Fell, 65.

72 Rex Stewart, "The Cutting Sessions," in Reading Jazz: A Gathering of Autobiography, Reportage and Criticism from 1919 to Now, ed. Robert Gottlieb (New York: Pantheon, 1996), 387.

${ }^{73}$ William Taylor, "Jazz Piano: History and Development: A New Perspective for Educators," (EdD diss.,
} University of Michigan, 1975), 59-60. 
The evolution of the cutting contest dates back to the nineteenth century. Slaves on southern plantations participated in cakewalk dances where the winner received an enormous cake. In the late nineteenth century, Mississippi riverboats lined up alongside one another and their bands would play at each other. Perseverance and unity marked the winners of riverboat competitions. Around the same time brass bands battled in the streets of New Orleans, in which two ensembles simultaneously played different repertoire. One band eventually dropped out due to the cacophony generated from the clashing ensembles. However, the band that continued playing won the contest. Southern African-American musicians brought these competitive traditions with them when they migrated to New York and other northern cities during the early twentieth century. Harlem cutting contests, a continuation of these late nineteenth century competitions, involved two or more pianists striving for recognition as the best performer. ${ }^{74}$

Duke Ellington once explained the importance of the cutting contest, asserting that "Anybody who [wanted] a reputation as a piano player had to prove it right there and then by sitting down to the piano and displaying his artistic wares." ${ }^{, 75}$ The victor did not receive a monetary reward. However, demonstrating artistic and technical superiority helped musicians land better jobs. ${ }^{76}$

Amateurs had to earn the right to engage in battles with the stride elite. ${ }^{77}$ From the late 1910s until the mid-1930s James P. Johnson sat atop the stride hierarchy with Willie "the Lion" Smith and Fats Waller following close behind. ${ }^{78}$ In Duke Ellington's foreword to Willie “the

\footnotetext{
${ }^{74}$ Katherine Walker, "Cut, Carved, and Served: Competitive Jamming in the 1930s and 1940s,” Jazz Perspectives (August 2010): 184-185.

${ }^{75}$ Gioia, 98.

${ }^{76}$ Stewart, 387.

${ }^{77}$ Ibid., 387.

${ }^{78}$ Barnhart, 850 .
} 
Lion" Smith's autobiography Music on My Mind, Ellington described how Smith addressed [ill-

suited] aspirants who challenged his throne:

Before he got through too many stanzas the Lion was standing over him, cigar-blazing. Like if the cat was weak with the left hand, the Lion would say, "What's the matter, are you a cripple?" Or, "When did you break your left arm?" Or, "Get up, I will show you how it's supposed to go.",79

In an interview with jazz critic Nat Hentoff, Garvin Bushell, a former employee at

Leroy's, provided his observations from cutting contests that took place during the 1920s:

It was at Leroy's that I first saw piano battles. Players like Willie the Lion, James P., Fats, Willie Gant. They'd last for three or four hours. One man would play two or three choruses, and the next would slide in. Jimmy was on top most of the time. Fats was the youngest, but he was coming along. They played shouts and they also played pop tunes. You got credit for how many patterns you could create within the tunes you knew, and in how many different keys you could play. You had to know how to play in every key because all those players had been baptized in cabarets. You never knew what kind of key the entertainers wanted.

There'd be more controversy among the listeners than the participants. There was betting, and people were ready to fight about who'd won. Jimmy played with the most originality. He'd create things the other guys hadn't thought up. ${ }^{80}$

Several infamous cutting contests happened during the 1920s and 1930s. One such fiery contest involved three legendary jazz pianists: Jelly Roll Morton, Willie "the Lion" Smith, and James P. Johnson. Rex Stewart, a renowned trumpet player, details the contest in an article he wrote in Down Beat in 1967:

...Jelly Roll Morton swaggered up to the piano in the Rhythm Club announcing that he, the king of the ivory ticklers, was ready for all turkeys (a not-so-flattering way of referring to any possible competition). Making such a proclamation was like waving a red flag in front of a bull.

\footnotetext{
${ }^{79}$ Gioia, 98 .

${ }^{80}$ Nat Hentoff, “Garvin Bushell and the New York Scene,” The Jazz Review (February 1959): 10.
} 
...[after Morton performed a few tunes Willie "The Tiger" Gant] phoned Willie "the Lion" Smith to come right down. I don't think Jelly Roll and Willie had ever met, but the air became charged with professional animosity when The Lion hit the scene and snarled, "Either play something or get up, you heathen. The lion is in port, and it's my mood to roar!" Such an unfriendly put-down caused Jelly to tear into a fast rag, which brought the house down. Morton, hearing the applause looked up from the piano, sweating and beaming. Evidently he felt that there would be no contest.

The Lion, unimpressed, just pushed Jelly off the piano stool and, without breaking the rhythm of Jelly's tour de force, played one of his own rags with equal skill and just as great an impact on the audience.

The duel had taken on the aspect of a standoff, so the call went out for Fats Waller, but Fats was nowhere to be found. Just then, the all-time boss of the Harlem stride piano players, James P. Johnson, arrived, having been advised of what was going on via the grapevine.

James P., who sometimes stuttered, said, "Jelly come on, 1-1-let's go down to the Hoofers. They have a b-b-better piano there, and I'll entertain you."

Jelly agreed, and everybody followed. As I recall, there were about sixty or seventy cats in the "second-line" 81 on that occasion. History was made as James P. wiped up the floor with Jelly Roll. ${ }^{82}$

The most legendary of all piano cutting contests, involving Art Tatum, James P. Johnson, Fats Waller, and Willie "the Lion" Smith, occurred in New York during the early 1930s. Tatum had traveled from Toledo to accompany a singer at Adelaide Hall. Word about Tatum's tremendous piano skills spread around New York's musical community. Waller, Smith, and Johnson, fed up with the rumors, brought Tatum to a local Harlem nightspot for a cutting contest. ${ }^{83}$ Maurice Waller describes this legendary session in a biography of his father in 1977 :

81 "Second line" is a reference to the people who danced, sang, and shouted behind parade bands in New Orleans during the late nineteenth and early twentieth centuries. Sidney Bechet, "Sidney Bechet," in Reading Jazz: A Gathering of Autobiography, Reportage and Criticism from 1919 to Now, ed. Robert Gottlieb (New York: Pantheon, 1996), 11-12.

${ }^{82}$ Stewart, 388-389.

${ }^{83}$ Gioia, 103. 
When it came Tatum's time to play, he let loose with a dazzling "Tea for Two" full of dense harmonies and sweeping runs and arpeggios that left the audience speechless. James P. Johnson gamely followed with his "Carolina Shout," and Waller checked in with his "Handful of Keys," but Tatum responded with a virtuoso version of "Tiger Rag," taken at a breakneck tempo, that made comparisons pointless. Johnson returned to the keyboard with a final fiery rendition of Chopin's "Revolutionary Etude," and though Waller later said he had never heard this elder statesman of stride play quite so well, the final verdict was no longer in doubt. "That Tatum, he was just too good," Waller later recollected. "He had too much technique. When that man turns on the powerhouse, don't no one play him down. He sounds like a brass band." James P. Johnson, for his part, later mused, "When Tatum played 'Tea for Two' that night, I guess that was the first time I ever heard it really played." 84

In the memoirs of Willie "the Lion" Smith and James P. Johnson, they cited three

musical skills that contributed to their success at cutting contests. First was knowing how to read music. A significant number of ragtime pianists of the early 1900s had inadequate music reading abilities. ${ }^{85}$ Many of the elite stride pianists, such as Luckey Roberts, played by ear for a number of years before recognizing the importance of reading music. ${ }^{86}$ Second was the ability to create flashy yet melodic improvisations. ${ }^{87}$ To learn how to improvise, stride pianists would carefully listen to live performances and piano rolls. ${ }^{88}$ Finally, the capability to play in every key. ${ }^{89}$ Eubie Blake, one of the first ragtime pianists that could play in all keys, strongly encouraged Johnson to develop this skill. ${ }^{90}$ Starting in the mid-1910s Johnson made it a point to practice his repertoire in every key. Johnson passed Blake’s advice onto his protégés Smith and Waller. ${ }^{91}$ Accounts by

\footnotetext{
${ }^{84}$ Maurice Waller and Anthony Calabrese, "Fats Waller," in The History of Jazz, ed. Ted Gioia (New York: Oxford University Press, 1997), 103.

${ }^{85}$ Riis, 63.

${ }^{86}$ Davin, 174-175.

${ }^{87}$ Riis, 63.

${ }^{88}$ Davin, 174-175.

${ }^{89}$ Riis, 63.

${ }^{90}$ Gunther Schuller, Early Jazz: Its Roots and Musical Development (New York: Oxford University Press, 1986), 215.

${ }^{91}$ David A. Jasen and Trebor Jay Tichenor, Rags and Ragtime: A Musical History (New York: Seabury Press, 1978), 242.
} 
colleagues of "Willie "the Lion" Smith indicate that he had over 500 songs in his active repertoire and could play most of them in any key. ${ }^{92}$

Luckey Roberts, James P. Johnson, and Fats Waller all developed these skills through their experience as theater accompanists. ${ }^{93}$ Some stride pianists practiced several hours a day to improve their playing. Stride performers were expected to play accurately and fast. Regarding practicing, Johnson said "[he] would play in the dark to get completely familiar with the keyboard. To develop clear touch and the feel of the piano, I'd put a bed sheet over the keyboard and play difficult pieces through it."94

To dazzle their audiences and competition, stride pianists incorporated what they called "tricks" (virtuosic, flamboyant, and mostly improvised four to eight-measure musical licks) into their performances. ${ }^{95}$ Some of the more common "tricks" include chromatic passages, sequential patterns, scalar sequences, and syncopated chords. ${ }^{96}$ The composer-pianist Eubie Blake once said: 'I don't play any better than any real pianist, but it's the 'tricks' I know. I know 'tricks' that the average guy don't know." ${ }^{, 97}$ The competitive nature of the style facilitated development of more complicated "tricks" during the late 1920 s and 1930s. ${ }^{98}$

James P. Johnson had an arsenal of challenging "tricks," such as rapid left hand tenths, double-glissandos straight and backhand, glissandos in sixths, and double tremolos, that quickly sent his competition looking for the exits. Additionally, Johnson's polished technique allowed him to execute these "tricks" with ease at breakneck speeds. ${ }^{99}$ Johnson stated that he learned

\footnotetext{
92 Alioso, 21.

93 Shipton, 121.

${ }^{94}$ Davin, 174-175.

95 Shipton, 131.

96 Taylor, 59-60.

97 Jasen and Tichenor, 241.

${ }^{98}$ Max Harrison, "James P. Johnson," in Reading Jazz: A Gathering of Autobiography, Reportage and Criticism from 1919 to Now, ed. Robert Gottlieb (New York: Pantheon, 1996), 845.

${ }_{99}$ Davin, 174.
} 
many of his "tricks" from the pianist Johnny Waters while on tour with the show Smart Set in 1918 and 1919. ${ }^{100}$

In addition to "tricks," some Harlem pianists wrote and performed extremely virtuosic compositions, such as Roberts' Nothin, to impress their listeners. Most often the composer avoided performing these works until he needed to finish off a competitor at a cutting contest. Composers refrained from publishing such works to keep rivals from learning them, while the technical difficulties of these compositions made it nearly impossible for other pianists to learn by ear. ${ }^{101}$

Since the pianist served as the sole source of entertainment at rent parties and at clubs they had to consider every aspect of their performance - musical and non-musical. Not only did the performer need to play well, but the pianist had to consider how they dressed, talked, walked to the piano, and their body language while playing. ${ }^{102}$ Smith considered these traits just as important as performance skills. ${ }^{103}$

To make striking impressions on rent party and club crowds, Harlem pianists dressed in the finest clothes and sported extravagant accessories such as a cane and derby. ${ }^{104}$ The most luxurious dresser of all Harlem pianists was Willie 'the Lion" Smith. ${ }^{105}$ Jazz scholars David A. Jasen and Gene Jones provide the following description of Willie "the Lion" Smith's attire:

\footnotetext{
100 Shipton, 129.

101 Jasen and Jones, 54.

102 Terry Waldo, This is Ragtime (New York: Hawthorn Books, 1976), 115.

103 Gioia, 98.

104 Ibid., 99.

105 Davin, 176-177.
} 
His overcoat was a tasteful melton, with padded shoulders and plaid lining. His shoes were French, custom-made in the short-vamp style. The derby hat had been a Smith trademark since his days of passing it after dancing in Newark clubs, and he took to wearing one at the piano. His suits were conservative, but expensive. He preferred a single-breasted cut, to show the gold watch chain that dangled across his chest. And he had spats made from the suit material. A silk shirt was best, especially if it was warm enough to remove his suit coat... A cigar and a cane completed the picture of elegance... When the Lion entered a saloon, everyone knew a big shot had arrived. ${ }^{106}$

Rent party and club audiences carefully watched every move and gesture that the pianist made. Harlem pianists often made grand entrances which included a long strut to the piano. ${ }^{107}$ Jazz historian Nat Hentoff compared Willie "the Lion” Smith's walk to the keyboard to "Don Juan on the way to an assignation." ${ }^{108}$ Each pianist had a choreographed way of settling down to play. Typically, the pianist started their act by laying their cane on the music rack. Next, they took off their overcoat, folded it, and carefully placed it on the piano so that everyone could see the expensive lining. Then, while facing the audience the pianist took off their hat with a fancy flourish. Finally, the performer took out a large silk handkerchief and dusted off the piano bench or stool. Occasionally the pianist added a twist to their routine to grab the attention of a lady in the crowd. ${ }^{109}$

Once the pianist finished his elaborate entrance he sat down at the piano and struck his "signature" chord. According to Jelly Roll Morton everybody had a signature chord to "announce your presence." The pianist then proceeded to play a flashy opening tune to astound the crowd. ${ }^{110}$

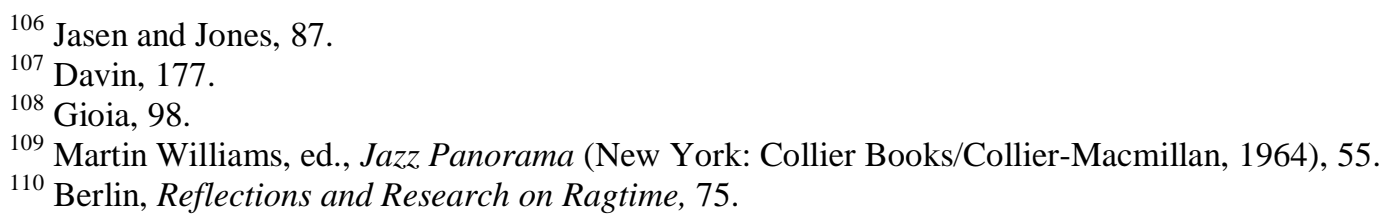


For the remainder of their performance the pianists picked repertoire to match the tastes and moods of their listeners. ${ }^{111}$ Audiences particularly enjoyed improvised rags on well-known classical pieces, popular melodies, and show tunes. For instance, James P. Johnson did rag variations on Rossini's William Tell overture, Grieg's Peer Gynt Suite, and Rachmaninoff's Prelude in C-sharp minor. ${ }^{112}$ In addition to playing music that the listeners wanted, pianists added theatrical effects, such as lifting their hands high above the piano, to add flair to a performance. $^{113}$

Stride pianists became local legends with their fancy attire, elaborate choreographed entrances, and virtuosic playing. A few stride pianists saw an opportunity to develop a national following during the 1920s by making and selling piano rolls. The rise in popularity of player pianos during the first three decades of the twentieth century greatly aided in the dissemination of stride. Although printed sheet music of ragtime and stride tunes was readily available to the public, many player-piano owners had insufficient technique and note-reading skills to play them. Buying piano rolls allowed Americans to enjoy the sound of ragtime and stride without the struggles associated with learning difficult pieces of music. ${ }^{114}$

Many middle-class Americans purchased player pianos as a sign of wealth and status. Buying a piano, around $\$ 250$ in the early 1900 s, often represented a family's second largest acquisition after their house. ${ }^{115}$ By the late 1910s the piano-player craze had spread across the Atlantic to Britain and continental Europe. The leading manufacturer of player pianos in America was “Aeolian Company." 116

\footnotetext{
${ }^{111}$ Williams, 55.

112 Davin, 175.

113 Gioia, 99.

${ }^{114}$ Michael Montgomery, Trebor Jay Tichenor, and John Edward Hasse, "Ragtime on piano rolls," in Ragtime: Its History, Composers, and Music, ed. John Edward Hasse (New York: Schirmer, 1985), 90.

115 Peretti, 14.

${ }^{116}$ Montgomery, Tichenor, and Hasse, 92.
} 
Chicago and New York, two of the most important centers of jazz during the 1920s, had the greatest concentration of piano-roll manufacturers. The successful piano-roll manufacturer, QRS, had locations worldwide including Toronto, Sydney, Utrecht, and New York. James P. Johnson and Willie "the Lion" Smith both made piano rolls for QRS in New York during their careers. ${ }^{117}$

The peak of piano-roll sales, 1920 to 1925, coincided with the emergence of stride. James P. Johnson made the two most popular piano rolls of the 1920s: Carolina Shout and Harlem Strut. ${ }^{118}$ Many stride pianists, such as James P. Johnson, made piano rolls and recordings of the same piece at different times during their careers. Due to the improvisational nature of the idiom, stride pianists rarely played a tune the same way. This is evident when listening to and comparing different piano rolls to later recordings of the same piece, such as Johnson's Carolina Shout. ${ }^{119}$

Producing piano rolls was an important source of income for many of the stride pioneers. However, the rise of the radio and phonograph led to the decline of player-piano and piano-roll sales. By the mid-1920s most stride pianists had ended their contracts with piano-roll companies and entered the world of studio recording. ${ }^{120}$

By the late 1930s stride had fallen out of style in favor of swing and be-bop. Only a few pianists, such as Dick Wellstood, continued playing stride into the 1940s and beyond. Stride flourished in clubs and rent parties of Harlem. However, by the late 1930s New York's jazz

\footnotetext{
${ }^{117}$ Ibid., 94-96.

${ }^{118}$ Ibid., 92-98.

119 Jasen and Tichenor, 241.

${ }^{120}$ Montgomery, Tichenor, and Hasse, 92-93.
} 
scene migrated back to midtown Manhattan. Clubs along 52nd street, such as "The Onyx," became important venues of the bop era. ${ }^{121}$

Stride performers significantly raised the standard of jazz playing. Their quest for perfection, virtuosic technique, and competitive spirit had a great influence on bop and other later jazz styles.

${ }^{121}$ Gioia, 216-218. 


\section{Chapter Two}

\section{Biographies}

Many Harlem pianists, such as Willie Gant, had successful careers as club and rent-party musicians during the late 1910s on through the mid-1930s. However, four pianists, Luckey Roberts, James P. Johnson, Willie "the Lion Smith, and Fats Waller, emerged as pre-eminent leaders of the style. In this chapter the lives and careers of these four pianists are examined.

Charles Luckeyth Roberts, nicknamed Luckey, was the first major Harlem rag player and composer. There is discrepancy regarding his date of birth. The majority of scholars of Roberts cite August 7th, 1887 as Luckey’s birthdate. However, Henry T. Sampson asserts in his book Blackface: a Source Book on Early Black Musical Shows (Metuchen, NJ, 1980) that Roberts inked August 7th, 1893 as his birthdate when applying for a social-security card. ${ }^{122}$ For the purposes of the following discussion the 1887 date will be referenced.

Roberts and his family resided in Philadelphia during his childhood. ${ }^{123}$ By the time he turned five, Roberts had entered the world of Negro show business. He performed as a singer, dancer, and juggler in various shows, such as Uncle Tom's Cabin, and toured with two different vaudeville groups: "Gus Seeke’s Pickaninnies" and "Mayme Remington and Her Black Buster Brownie Ethiopian Prodigies." ${ }^{24}$ By the time Luckey turned ten years old he had toured in Europe three times. ${ }^{125}$

Luckey gained an interest in the piano around age six. The "Remington Prodigies" often stayed at hotels and boarding houses, many of which had pianos. Fascinated with the instrument,

122 J. R. Taylor and Barry Kernfeld, "Roberts, Luckey." In The New Grove Dictionary of Jazz, 2nd ed., edited by Barry Kernfeld. Grove Music Online. Oxford Music Online (accessed May 15, 2012),

<http://www.oxfordmusiconline.com/subscriber/article/grove/music/J381800>

${ }^{123}$ Jasen and Tichenor, 187.

124 Vinding and Fell, 25-26.

125 Jasen and Jones, 53. 
Luckey would dabble around on these pianos in between shows. His father observed that his son had a musical gift and arranged for him to meet Lonnie Hicks, a Philadelphian ragtime player. Hicks encouraged Luckey to practice hard and consistently. From that point forward, Luckey would practice several hours during the day and perform with the Remington Prodigies in the evening. ${ }^{126}$

Luckey started performing as a solo pianist and vocal accompanist at the Green Dragon saloon in Philadelphia around 1900. A short time later, Roberts left Philadelphia for New York. As a self-taught pianist, Luckey came to the city lacking two important skills required to succeed in New York's competitive music scene: the ability to read music and the facility to play in all keys. Fortunately for Luckey, a local classical pianist and fan of his playing, Ernest Green, stressed the importance of reading music and recommended teachers to Luckey. From that point forward, when Luckey could afford it, he took formal lessons in piano, counterpoint, and composition. $^{127}$

By 1910 Luckey had developed a virtuosic piano technique. Although short in stature (four feet, ten inches), Roberts had long arms and massive hands that could stretch fourteen keys, just short of two octaves, allowing him to play with tremendous power. ${ }^{128}$ For example, he could rip off chromatic runs that often extended for three or more octaves. ${ }^{129}$ James P. Johnson spoke highly of Roberts' playing, stating:

\footnotetext{
126 Ibid., 53.

127 Ibid., 53.

128 Jasen and Tichenor, 187.

${ }^{129}$ Waldo, 112.
} 
Luckey Roberts was the outstanding pianist in New York in 1913 and for years before and after... he played tenths as easy as others played octaves. His tremolo was terrific, and he could drum on one note with two or three fingers in either hand. His style in making breaks was like a drummer's; he'd flail his hands in and out, lifting them high. A very spectacular pianist. He was playing at Barron Wilkins' place in Harlem then, and when I could get away, I went uptown and studied him. Later we became good friends, and he invited me to his home. ${ }^{130}$

During the 1910s Roberts performed regularly at Barron Wilkins' Little Savoy Club and soon established himself as one of New York's top players. In 1913 the Joseph Stern Company published his The Junk Man Rag and Pork and Beans, two of the earliest printed rags composed in the stride style. Other major works that he wrote over during the mid-1910s include The Music Box Rag and Palm Beach in 1914, and Shy and Sly in $1915 .{ }^{131}$ All of these piano rags have connections with popular dance trends of the time, such as the fox-trot. ${ }^{132}$

According to Terry Waldo, a scholar and performer of ragtime, the sophistication and virtuosity of Luckey's rags made them nearly impossible for anyone else to play. Consequently, Roberts either greatly simplified his rags before publishing them, or, in some cases, chose not to print them at all. ${ }^{133}$ One such virtuosic piece never published, Ripple of the Nile, contains technical problems, such as relentless strings of triplets, that stumped even the best pianists of Luckey's day. James P. Johnson and George Gershwin both acknowledged that they could not master the musical challenges found in this rag. ${ }^{134}$

Luckey shifted his focus towards writing musical revues and Broadway shows during the late 1910s. His interest in this avenue of entertainment dates back to circa 1912 when he played a small role in the Darktown Follies hit My Friend from Dixie. In 1917 the Tutt-Whitney

\footnotetext{
${ }^{130}$ Tom Davin, “Conversations With James P. Johnson,” The Jazz Review (July 1959): 12.

131 Jasen and Jones, 53-57.

132 Waldo, 112.

${ }^{133}$ Ibid., 112.

134 Jasen and Jones, 56.
} 
Company, a producer of black touring shows, hired Roberts to write the score for My People. He wrote two more scores for Tutt-Whitney in 1919, Smart Set and Darkest Americans. ${ }^{135}$

Roberts collaborated with Alex Rogers, one of the most respected lyricists of the time, to produce a number of comedies for musical theater throughout the first half of the $1920 \mathrm{~s}$. Together they wrote two musical comedies for the Quality Amusement Company: Baby Blues in 1919 and This and That in 1920. They collaborated on several other musical shows including Go-Go and Sharlee in 1923, Steppin' Time in 1924, and My Magnolia in 1926. Roberts also worked with several other lyricists during the early 1920s to write several successful songs, including Railroad Blues, Tallahassee, Goo Googily Goo, and I Want a Good Baby Bad. ${ }^{136}$

Luckey did not totally abandon his piano interest while writing theatrical music. He frequently performed at Barron Wilkins’ new club in Harlem. ${ }^{137}$ Additionally, Luckey made piano rolls in 1919 and $1923 .^{138}$ Roberts' contemporaries surpassed him in terms of the volume and permanence of his works. For example, Luckey only produced five piano rolls compared to Fats Waller's twenty-four and James P. Johnson's fifty-four. ${ }^{139}$

In 1924 Luckey accepted an elite social-function gig at the Everglades Club in Palm Beach, a resort for New York snowbirds. ${ }^{140}$ Soon after, members of high society began requesting Luckey to provide entertainment for their various social functions. Over the next several years, he performed at various locales along the east coast including Newport, Boston, and New York. Roberts remained popular among members of high society, such as Franklin Roosevelt, the Vanderbilts, and the Rockefellers, for a number of years. ${ }^{141}$ These elite social

\footnotetext{
135 Ibid., 54-57.

136 Ibid., 57-61.

137 Ibid., 57.

138 Taylor and Kernfeld.

139 Jasen and Jones, 52.

${ }^{140}$ Ibid., 61.

${ }^{141}$ Vinding and Fell, 87.
} 
functions made Luckey one of the nation's best paid entertainers. Eventually, the depression reached the point that even the millionaires started to cut back on their spending. After nearly a decade as an elaborate entertainer, Luckey's high society gigs came to an end. ${ }^{142}$

When his society jobs ended, Roberts started to experiment with symphonic writing. On August 30th, 1939, he presented a concert of his "legitimate" music at Carnegie Hall. Luckey had an automobile accident in July of 1940 and suffered several injuries, including crushed hands and ankles. Most people believed the injuries from his accident would end his career. However, he quickly recovered and less than a year later he performed a concert at Town Hall in New York on May, 28th $1941 .^{143}$

Roberts wrote his first hit song, Moonlight Cocktail, in 1942. To create this hit ballad he took the "A" section of his unpublished Ripples of the Nile, and slowed it to a crawl. Moonlight Cocktail sat atop the Billboard charts for nineteen weeks thanks to the popular recording of the work by the Glenn Miller Orchestra with vocal support by Ray Eberle and the Modernaires. With the income he earned from the sales of Moonlight Cocktail and another semi-popular song Massachusetts, he bought a small Harlem bar in 1942 and named it Luckey's Rendezvous. Luckey ran the Rendezvous for twelve years. ${ }^{144}$

Luckey made no recordings during his heyday, and compared to other prominent stride pioneers, had a significantly smaller recording output. J. R. Taylor and Barry Kernfeld, scholars of jazz, suggest that Luckey's society jobs of the 1920s and 1930s provided him with a financially satisfying and rewarding career, and therefore Roberts felt no need to record. ${ }^{145}$ Roberts did make two recordings, Shoo Fly and Shy and Sly for Columbia in October of 1916.

\footnotetext{
142 Jasen and Jones, 63.

143 Ibid., 63.

144 Ibid., 63-64.

145 Taylor and Kernfeld.
} 
However, for unknown reasons the producers for Columbia chose not to release the two tracks. ${ }^{146}$ Roberts waited three decades before making another solo piano recording. In 1946 he recorded Junk Man Rag, Pork and Beans, Music Box Rag, Railroad Blues, and Ripples of the Nile and Shy and Sly for Rudi Blesh's Circle label. In March of 1958 Nat Hentoff, a jazz critic, had Roberts and Willie "the Lion" Smith record an LP for the Good Time Jazz label titled Harlem Piano: Luckey and the Lion. The album includes Luckey's playing of Nothin, Railroad Blues, and a syncopated waltz, Inner Space. Shortly after making this recording, Luckey suffered a stroke that left him incapacitated for the last ten years of his life. Luckey passed away in New York on February 5th, $1968 .^{147}$

Roberts was the leader of stride during the mid-1910s, but by the late 1910s James P. Johnson had emerged as the new king of stride. James P. Johnson had a diverse musical career that included work in the jazz arena, the classical sphere, and in Negro show business. ${ }^{148}$ During his lifetime Johnson did not receive extensive recognition outside a close circle of followers. This is evident by the fact that Jazz.Hot and Hybrid or Jazzmen, influential books in their day, make no references to Johnson. ${ }^{149}$ Jazz historian Gunther Schuller suggests that the rise of orchestral jazz in the 1920s and 1930s overshadowed the solo piano style that Johnson helped pioneer. ${ }^{150}$

Those that did know of Johnson recognized his genius and imagination in piano playing. He had a lasting effect on a succession of musicians which constitute the elite of the jazz piano tradition including Willie “the Lion” Smith, Count Basie, Duke Ellington, Art Tatum, Earl

\footnotetext{
${ }^{146}$ Vinding and Fell, 26.

147 Jasen and Jones, 64.

${ }^{148}$ Willa Rouder, "Johnson, James P.." In Grove Music Online. Oxford Music Online (accessed May 15, 2012), <http://www.oxfordmusiconline.com/subscriber/article/grove/music/14409>

${ }^{149}$ Harrison, 848-849.

${ }^{150}$ Schuller, 214.
} 
Hines, Teddy Wilson, and Thelonious Monk. ${ }^{151}$ Johnson's playing had the greatest effect on the most popular of all the stride pianists, Fats Waller. ${ }^{152}$ In a published interview with Johnson, Conversations with James P. Johnson (New York, 1985), jazz scholar Tom Davin wrote, “Since James P. had such a strong influence on so many well-known pianists, it is amazing that most people have never heard of him."153

There is discrepancy regarding Johnson's birthdate. Trebor Jay Tichenor, Gunther Schuller, and Max Harrison cite Johnson's birthdate as February 1st, 1891. However, Gene Jones, Gerald S. Alioso, David Dicaire, John L. Fell, Terkild Vinding, and Willa Rouder list Johnson's birthdate as February 1st, 1894.

Johnson lived his early childhood in New Brunswick, New Jersey. His family purchased a piano in 1898. A short while later his mother taught herself how to play a few hymns and popular songs. Soon after, James, fascinated by his mother's playing, started to teach himself how to play. ${ }^{154}$ His family moved to Jersey City, near New York, in 1902. The sound of ragtime coming out of nearby saloons and bawdy houses in Jersey City further inspired Johnson. ${ }^{155}$ Sometime in 1902 a neighborhood businesswoman heard Johnson playing ragtime and asked if he would like to earn a quarter. Johnson obliged, so the lady took him inside a nearby building, sat him down at the piano, and told him to play and "Don't turn around!" Unknowingly at the time, young Johnson had made his brothel debut. ${ }^{156}$

In 1908 his family relocated again, this time to the "San Juan Hill" section of New York. Johnson took full advantage of the city's cosmopolitan musical atmosphere. He started visiting
${ }^{151}$ Ibid., 214.
152 Alioso, 23.
153 Davin, 166.
154 Jasen and Jones, 68.
155 Davin, 169.
156 Jasen and Jones, 69. 
the city's cabarets and sporting houses where he heard the stomp and rag styles of elite pianists such as Luckey Roberts, Eubie Blake, Abba Labba (Richard McLean), and Jelly Roll Morton. ${ }^{157}$ Johnson carefully listened to, absorbed, and emulated the music he heard from these ragtime pianists. During interviews late in his life, Johnson recalled specific "tricks" that he stole from Harlem pianists such as Fred Bryant ("He invented the backward tenth") and Sam Gordon ("He played swift runs in thirds and sixths, broken chords, one-note tremolandos"). ${ }^{158}$ Not only did he visit local cabarets and sporting houses to hear the finest Negro pianists on the east coast perform, but Johnson also attended orchestral concerts and piano recitals. Regarding his classical experiences, Johnson stated in interview with Tom Davin, "the full symphonic sounds made a great impression on me. That was when I first heard Mozart, Wagner, Von Weber, Meyerbeer, Beethoven, and Puccini." 159

Johnson's family relocated to uptown New York in $1911 .{ }^{160}$ Soon after, Johnson started playing in local cabarets, silent movie houses, rent parties, and during the summer months, at Atlantic City resorts. ${ }^{161}$ His name started to travel around the city and in the spring of 1913 , Drake's Dancing Class, better known as "The Jungles Casino" to its patrons, hired Johnson to play once a week. $^{162}$

Sometime in the early 1910 s Johnson met Ernest Green, the classical pianist who had befriended Luckey Roberts. Green provided Johnson the same advice that he had given Luckey: take formal lessons and learn the fundamentals of music. ${ }^{163}$ Green's mother studied piano with the Italian music teacher, Bruto Giannini. After Mrs. Green heard Johnson play she insisted that

\footnotetext{
${ }^{157}$ Schuller, 215.

${ }^{158}$ Harrison, 846.

${ }^{159}$ Davin, 169-170.

160 Jasen and Jones, 70.

161 Jasen and Tichenor, 242.

162 Jasen and Jones, 70.

163 Ibid., 71.
} 
he not waste his talent, and in 1914 arranged for Johnson to take lessons with Giannini. ${ }^{164}$ Over the next four years, Giannini taught Johnson classical theory, history, European keyboard literature, and proper piano technique while allowing him to continue performing rags and stomps, but with corrected fingering. ${ }^{165}$ Johnson supplemented his lessons by listening to the leading classical pianists of his day including Sergei Rachmaninoff, Vladimir de Pachmann, and Josef Casimir Hoffman. ${ }^{166}$

In 1915 Johnson cut a piano roll for the Aeolian Company. Prior to this, no AfricanAmerican had ever made a piano roll. By 1916 Johnson was making rolls on a regular basis for Aeolian. ${ }^{167}$ Johnson cut seventeen rolls in 1917 including Caprice Rag, Steeplechase Rag, Daintiness Rag, Innovation, and Twilight Rag. ${ }^{168}$ Many non-music-reading ragtime players across the country trained themselves by slowing down and studying Johnson's piano rolls. ${ }^{169}$ Johnson's career took a number of different directions in 1917. First, afraid of being drafted and having to serve time overseas during World War I, he took a "safe" job in a Quartermaster Corps warehouse. ${ }^{170}$ Second, Johnson published his first piece of sheet music, Stop It. ${ }^{171}$ Third, he organized combos and played for engagements with James Reese Europe's Clef Club. ${ }^{172}$ Finally, Johnson got his first theater experience, teaming up with Will Farrell, a

${ }^{164}$ Davin, 174.

165 Harrison, 846.

166 Schuller, 215.

167 Davin, 177.

168 Jasen and Jones, 72.

169 Davin, 177.

170 Jasen and Jones, 71.

171 Jasen and Tichenor, 246.

${ }^{172}$ In 1910 James Reese Europe founded the Clef Club and Clef Club Orchestra, America's first all African-American orchestra. The hundreds of members of the Clef Club dominated the Manhattan musical entertainment business for nearly a decade. Peretti, 17-18. 
young black lyricist, to write songs for touring revues, serving as music director of the Smart Set's My People, and briefly sharing a vaudeville bill with white ragtime player Ben Harney. ${ }^{173}$

Johnson gained a number of followers during the 1910s, notably, George Gershwin, who regularly haunted rent parties hoping to find Johnson in performance. By 1920 Johnson's colleagues considered him the best player on the stride circuit. His popularity in Harlem reached the point that he appointed Raymond "Lippy" Boyette, another Harlem pianist, as his unofficial agent. Lippy helped Johnson with managing his busy rent party schedule. ${ }^{174}$

In 1921 Johnson made his first phonograph recordings, laying down a series of solo performances of his own compositions for OK records and for the Black Swan label. ${ }^{175}$ Additionally, he signed as an exclusive QRS piano-roll artist, turning out rolls of tunes by Spencer Williams, Eubie Blake, Perry Bradford, and W. C. Handy, as well as his own rags. ${ }^{176}$ Johnson's recordings, in particular Carolina Shout, influenced a number of young pianists, especially Duke Ellington. ${ }^{177}$ Today, Johnson's earliest piano rolls and recordings provide a snapshot of the genesis of jazz as a distinct musical idiom. ${ }^{178}$

Johnson published only five rags during the 1920s: Carolina Shout, Scoutin'Around, Toddlin, Jingles, and Keep Off the Grass. There was a major problem for stride pianists who wished to publish their music; only professionals and a few amateurs had the technique to perform the music. Therefore, only a small market for publishing sheet music composed in a stride manner existed during the 1920s. ${ }^{179}$

\footnotetext{
173 Jasen and Jones, 71.

174 Ibid., 76-77.

175 Rouder.

176 Jasen and Jones, 77.

177 Alioso, 22.

178 Schuller, 214.

179 Jasen and Jones, 77-78.
} 
Although Johnson had great success on the Harlem piano circuit, he recognized that he needed a way to supplement his career and thus entered the world of Negro show business. In 1922 he took a position as musical director for the touring show Plantation Days. ${ }^{180}$ The following year he collaborated with Fats Waller to write his first Broadway musical Runnin' Wild, which ran for 213 performances and included two of his most famous tunes, Charleston and Old Fashioned Love. ${ }^{181}$ Johnson teamed up with Fats Waller and lyricists Henry Cramer and Andy Razaf in 1928 for the production of the Broadway show Keep Shufflin.' Johnson continued to write shows into the late 1930s; however, no subsequent revues yielded much success. ${ }^{182}$

Eventually Johnson's theatrical career could not support him financially. He turned to recording fees to supplement his income during the second half of the 1920s. Johnson collaborated and recorded with topnotch jazzmen such as King Oliver, Jabbo Smith, Louis Armstrong, and Buster Bailey. ${ }^{183}$ Many of the premier blues singers of the 1920s, such as Ethel Waters, Eva Taylor, and Rosa Henderson, requested him as their accompanist. ${ }^{184}$ In February of 1927 Johnson and Bessie Smith laid down fourteen sides for the Columbia label, including the tunes Backwater Blues, Blues Spirit Blues, Wasted Life Blues, and Worn Out Papa Blues. His ability to play the blues with several layers and to play flourishes of blues notes in the right hand, all while keeping a steady rhythmic left hand, made him the ideal accompanist for these singers. ${ }^{185}$

Johnson's career took yet another direction in the late 1920s. He started composing orchestral works that blended elements of jazz, classical, and Negro folk traditions. The earliest

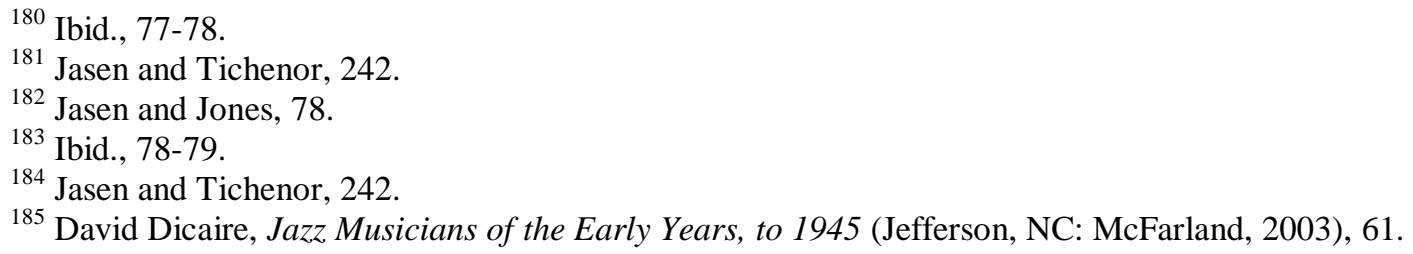


example of his work in this genre, Yamekraw: a Piano Rhapsody, premiered in April of 1927 at Carnegie Hall with Fats Waller as the soloist. ${ }^{186}$ Orchestras continued to program Yamekraw for about ten years after the premiere. ${ }^{187}$ Pleased by the audience's enthusiasm for Yamekraw, Johnson continued to write in this style into the 1930s, including the pieces Harlem Symphony, Jasmine Concerto, Symphony in Brown, and the one-act 'blues opera,' De Organizer. A lack of enthusiasm for these subsequent larger works, from both audiences and conductors, left Johnson feeling hurt and disappointed. Only sporadic performances of his symphonic works occur today. However, Duke Ellington would later follow in Johnson's footsteps in his work in the symphonic area in the piece Black, Brown, and Beige and Harlem."

Johnson experimentation in the classical sphere during the 1930s had caused him to fall out of favor with the musical tastes of the African-American community. ${ }^{189}$ His out-of-focus orchestral ambitions, the economic hardships caused by the Depression, and the rise of orchestral jazz sent him into economic turmoil. ${ }^{190}$ Johnson got his career back on track in December of 1938 when he performed several piano solos at Carnegie Hall. By next year he had fully revived his career, performing and dazzling audiences with his technical powers. ${ }^{191}$

In August of 1940, Johnson's revival took a setback when he suffered the first of a series of strokes that would plague his last years. After taking some time off to recover, Johnson made a brief yet strong re-entry into the jazz field in 1943. He performed at venues such as Jimmy Ryan's, Onyx, and Small's Paradise. Additionally, he laid down several tracks for the Blue Note and Signature Labels, including Carolinao Balmoral, Blues for Fats, Caprice Rag, and

\footnotetext{
${ }^{186}$ Gioia, 97.

187 Jasen and Jones, 79.

188 Gioia, 97.

189 Dicaire, 62.

190 Schuller, 214.

191 Dicaire, 62.
} 
Improvisations on Pinetop's Boogie. His revitalized career took another blow in December of 1943 when Fats Waller passed away. Johnson took Waller's death extremely hard and entered into a deep depression. ${ }^{192}$ During the remainder of the decade he took part in Eddie Condon's New York Town Hall concerts, appeared on Rudi Blesh's “This is Jazz" radio show, and gave a concert of his classical works with the Brooklyn Symphony Orchestra. In 1951 he had a major stroke which disabled him for the final four years of his life. He passed away in New York on November 17th, $1955 .{ }^{193}$

The one person who had the technique to challenge Johnson at rent parties during the late 1910s and 1920s was Willie Henry Joseph Bonaparte Berthloff Smith, born in Goshen, New York on November 25th, 1897. ${ }^{194}$ John L. Fell and Terkild Vinding, jazz scholars, provide an explanation for the complication of his full name in Stride! Fats, Jimmy, Lion, Lamb, and All the Other Ticklers: "Joseph was biblical, Bonaparte [was] French, Bertholoff his real father, and Smith his stepfather. William and Henry were included, he said, for spiritual balance." ${ }^{\prime 195}$ Smith's temper, flair, and loud mouth made him notorious in Harlem. Willie "the Lion" Smith flourished in the Harlem piano circuit for several decades. However, the accomplishments of his contemporaries, such as Waller and Johnson, often overshadow Smith's career. Smith never produced a hit record or a hit song and he published only a few of his scores. ${ }^{196}$ Nonetheless, his playing and compositions won him the respect of many elite jazz musicians, including Duke Ellington, Count Basie, and Dizzy Gillespie. ${ }^{197}$

192 Jasen and Jones, 79-80.

${ }^{193}$ Jasen and Tichenor, 242-243.

${ }^{194}$ Bill Dobbins and Barry Kernfeld, "Smith, Willie "the Lion"." In The New Grove Dictionary of Jazz, 2nd ed., edited by Barry Kernfeld. Grove Music Online. Oxford Music Online (accessed May 15, 2012), <http://www.oxfordmusiconline.com/subscriber/article/grove/music/J418400>

${ }^{195}$ Vinding and Fell, 109.

${ }^{196}$ Jasen and Jones, 83-99.

${ }^{197}$ Jasen and Tichenor, 249. 
In 1901 Willie's mother married his stepfather and they moved to Newark. In the basement of their new home, Willie discovered a pump organ that the previous owners had left behind. The family moved the organ upstairs and his mother, a church organist, started teaching Willie hymns and old pop songs that she knew. A few years later, Willie attained a piano from a local music store after winning a contest sponsored by a local newspaper. Soon after, he started teaching himself the ragtime songs he heard emanating from nearby dance halls. ${ }^{198}$

By 1911 Willie's uncle had started taking him to dancehalls and saloons in Newark. When Smith entered his early teenage years, he started making trips on his own to Manhattan to hear pianists at Jim Allan's, “The Jungles Casino,” and Barron Wilkins.' During these excursions, Smith carefully watched the pianists. He not only focused on their playing, but studied and emulated their behavior and mannerisms. Whenever the pianist left the stool for a break, Willie quickly took his place at the instrument, pounding out the few tunes that he knew. ${ }^{199}$

Smith's only musical training through his early teenage years came from his mother. He had developed a good ear, but could not read music. In 1915 Smith met a piano accompanist named Arthur Eck who wanted to learn how to play the ragtime "tricks" that he had heard Smith perform. The two young men saw a perfect opportunity to learn from each other. Eck taught Smith how to read music, and in exchange Smith showed Eck how to play his ragtime "tricks.",200

In 1916 Smith joined the 15 th Infantry Regiment, New York City’s black unit. ${ }^{201}$ When the United States entered World War I in April of 1917 his unit went to France. ${ }^{202}$ During his

\footnotetext{
198 Jasen and Jones, 84-85.

199 Ibid., 84-85.

${ }^{200}$ Ibid., 85.

${ }^{201}$ Vinding and Fell, 110.
} 
tour Smith served as a drum major in the "Black Devils' Band" of the 350th Field Artillery. ${ }^{203}$

On the battlefield Willie gained a reputation for his accurate and devastating shooting. Due to his sharp shooting and heroism his commander nicknamed him "a lion with a gun," and he proudly carried the nickname the rest of his life. ${ }^{204}$

When the army discharged Smith in 1919 he returned to New York and moved into Lottie Joplin's boarding house. After the great ragtime composer Scott Joplin passed away in 1917, his wife Lottie turned their residence at 163 West 131st Street in New York into a boarding house for musicians and theater people. According to Smith, it "was where all the bigtime theatrical people stayed and everything was free and easy." ${ }^{205}$ Interestingly, some of the leading jazz figures in New York, such as Eubie Blake and James P. Johnson, gathered on occasions at Lottie's house to play the piano late into the night. ${ }^{206}$

Smith wasted no time in making his name known in the stride circuit after his return from Europe. In 1919 he started his two year performing tenure at Leroy Wilkins' place. The following year Smith performed as a sideman on the historic recording of Crazy Blues with Mamie Smith and Her Jazz Hounds. ${ }^{207}$ When his tenure at Leroy Wilkins' place ended, Smith toured with several obscure shows. ${ }^{208}$ He returned to Harlem in 1923 and started performing at the Garden of Joy, the Capitol Palace, and the Rhythm Club. ${ }^{209}$

During the early 1920s Smith based his performance style and repertoire on the ragtime tradition of the previous decade. However, his mentor and the best pianist on the stride circuit, James P. Johnson, had started playing in a flashier and more virtuosic style that left his

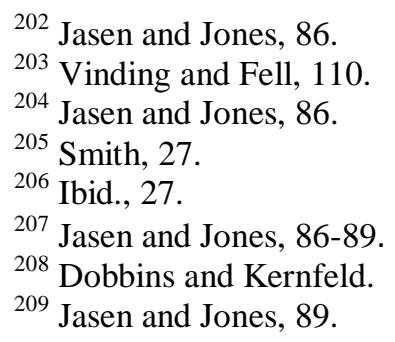


competition and audiences in awe. Smith recognized that he needed to adapt his playing style to remain on top of the Harlem piano circuit. Over the next few years, Smith assimilated Johnson's ideas into his own playing and soon made the transition from a ragtime pianist to a stride pianist. ${ }^{210}$ This transition is discussed in the next chapter.

As Smith's playing career continued to blossom, his flamboyant personality emerged. To make striking impressions on his audiences and competition, Smith wore elaborate clothing and acted theatrically while performing. He often displayed a nasty temper that instilled fear in everybody. An out-of-tune piano, a broken string, or ill-equipped dressing room made "the Lion" "roar." Furthermore, Smith developed a high opinion of himself. With the exception of Roberts, Blake, Johnson, and Waller, he considered his contemporaries poor musicians and pronounced his claims loudly. ${ }^{211}$ Eubie Blake provided his take on Smith's personality stating:

Of course the Lion never had nothing good to say about anybody, you know. Big mouth, But the Lion could play! He could play. But Willie always wanted to be the whole show. I guess he thought that if you always put the other guy down, it made you look good. But things don't work that way. Willie was good enough that he didn't need to act that way. $^{212}$

In the second half of the 1920s Smith recorded as a sideman with several short-lived bands and for a few minor recordings. His first work in this field occurred in November of 1925 when he recorded with the Gulf Coast Seven session for Columbia. Smith returned to the recording studios in 1927 to collaborate with Perry Bradford's Georgia Strutters on a two-sided disc for the Harmony label. In 1929 he teamed up with Clarence Williams' Seven Gallon Jug Band to make two sides for Columbia. ${ }^{213}$

\footnotetext{
${ }^{210}$ Ibid., 88-89.

211 Ibid., 86-89.

212 Ibid., 88.

213 Ibid., 89-90.
} 
By the end of the 1920s, Smith recognized that he had a major flaw- a lack of musical fundamentals. Due to his limited theoretical knowledge he only published one work during the 1920s, Keep Your Temper. To remedy this problem Smith started taking formal music lessons in 1930 with the German professor Hans Steinke. Over the next two decades, Steinke taught Smith theory, harmony, counterpoint, and classical piano. In Smith's autobiography he reflects on his classical training stating, "The trouble with most piano players is that they don't play enough Bach. Bach develops the left hand."214

As a result of his formal studies with Steinke, Smith refined his compositional approach. In 1934 he published his second composition for solo piano, Finger Buster. In this work, he demonstrates a new compositional manner that blends elements of pop, stride, and classical styles. ${ }^{215}$ He published three other stride compositions during the decade including In the Groove (1936), Sneak Away (1937), and Keep Fingering (1938). ${ }^{216}$

Smith's name remained virtually unknown outside of Harlem during most of the 1920s and early 1930s. The dissemination of piano rolls and recordings had made two of his contemporaries, Johnson and Waller, known outside of Harlem. However, Smith never cut a piano roll and did not make solo piano recordings until the mid-1930s. ${ }^{217}$ Not until Smith started performing at Pod's and Jerry's during the mid-1930s did his name start to travel outside of Harlem. ${ }^{218}$ While employed at Pod's and Jerry's, Smith acquired an impressive fan base that included Bix Beiderbecke, Jack Teagarden, Benny Goodman, Artie Shaw, and Hoagy Carmichael. $^{219}$

\footnotetext{
214 Ibid., 91.

215 Ibid., 91-92.

216 Jasen and Tichenor, 250.

217 Jasen and Jones, 89.

218 Jasen and Tichenor, 249.

219 Jasen and Jones, 90.
} 
Smith made his first solo piano recording in May of 1934, laying down Finger Buster for ARC. He returned to the studios the following year to record Harlem Joys for the Decca label. Two years later, Smith's recording career hit a snag. Decca signed Smith to a one-year contract in 1937. Decca officials hoped that Smith could help rejuvenate the music of the electric organist Milt Herth whose Dixieland style had yet to make single hit recording. Decca records believed that an ensemble which included Smith on piano, O'Neil Spencer on drums, and Teddy Bunn on guitar, would spice up Herth's music and start producing hit songs. With the new personnel Herth's music improved slightly, but still did not yield the success Decca had wished for. Smith, frustrated with the time he had wasted in the Herth quartet, left Decca records for Commodore the moment his contract expired. In January of 1939 he produced a set of historic recordings for Commodore. ${ }^{220}$ These fourteen tracks, including eight of his own compositions, illustrate the full maturity of his style and classical training. For example, Passionette makes use of counterpoint, Finger Buster has passages of extreme virtuosity, and Echoes of Spring has impressionistic qualities. ${ }^{221}$

At the turn of the decade, Smith recorded a set of duo blues tracks with Joe Turner and recorded twice with the Bechet Trio. Performances of his arrangements by the Artie Shaw and Tommy Dorsey bands helped his popularity to increase during the early part of the $1940 \mathrm{~s}^{222}$ Smith's mother passed away in 1944. In search of comfort he stopped his musical activities and joined a black Jewish congregation in Harlem. After finding the spiritual support he needed, Smith returned to the music scene and started teaching for the first time. Some of his most notable pupils include Mel Powell, Joe Bushkin, Dick Wellstood, and Mike Lipskin. ${ }^{223}$

\footnotetext{
${ }^{220}$ Ibid., 91-94.

${ }^{221}$ Dobbins and Kernfeld.

222 Ibid.

223 Jasen and Jones, 97.
} 
Throughout the remainder of the decade Smith performed regularly with Max Kaminsky's band at the Pied Piper in New York. ${ }^{224}$

Smith continued to perform in jazz festivals in America and abroad and to record during the last two decades of his life. Smith went on his first international tour in December of 1949, performing at jazz festivals and clubs in Europe for six weeks. While in Paris, Smith made the first of several "memoirs" albums, which include him playing, singing, and reminiscing. He returned to New York in 1950 and produced his best studio work, re-recording his eight original compositions from his historic 1939 session. He made two other noteworthy albums during the 1950s: The Lion Roars and The Legend of Willie (the Lion) Smith. ${ }^{225}$ In 1964 Smith sat down with George Hoefer to write his autobiography, Music on My Mind. ${ }^{226}$ Four years later, Smith recorded a two-album set titled The Memoirs of Willie the Lion Smith for the RCA Victor label. He headlined a few jazz festivals in the early 1970s before passing away in New York on April 18th, $1973 .^{227}$

The popularity of the final pianist discussed in this chapter, Thomas "Fats" Waller, far exceeded that of all the other New York stride pianists during the 1920 s and 1930 s. $^{228}$ He had the utmost admiration of music lovers nationwide and achieved celebrity status. The combination of his ebullient personality and wide smile captivated his audiences. ${ }^{229}$ Waller knew how to have fun, filling each individual moment with good times. ${ }^{230}$

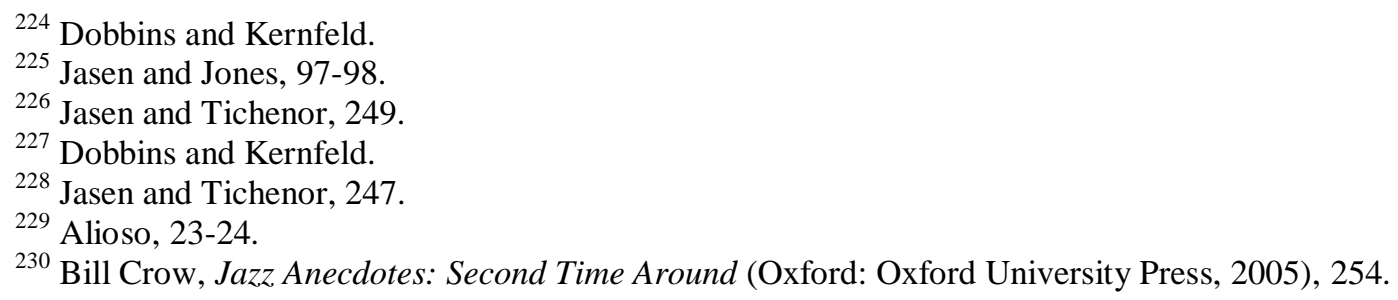


Waller polished the stride style that his predecessors had pioneered, and laid the foundation for future vernacular and jazz keyboard styles of the 1940s and beyond. ${ }^{231}$ According to Schuller, Waller took the "still somewhat disjunct elements of Johnson's style and unified them into a single, cohesive jazz conception in which ragtime was still discernible underneath the surface as a source, but no longer overtly active as a separate formative element." ${ }^{, 232}$ Additionally, Waller's use of sophisticated harmonies and consistent swinging rhythms transformed the stride idiom. ${ }^{233}$

Waller was born in New York on May 21st, 1904. He grew up in a deeply religious family. His father was the minister at the Abyssinian Baptist Church in Harlem where his mother played harmonium and organ. ${ }^{234}$ When Waller turned six his mother showed him how to play hymns on the harmonium. Additionally, his parents noted their son's fascination with the neighbor's piano and decided to enroll Waller in piano lessons. Although Waller demonstrated strong musical inclinations his teacher disapproved of his lack of practice and discontinued his lessons. $^{235}$

During the early 1910s Fats played violin in his school's orchestra. The director of the ensemble, Edgar Sampson, went on to work with some of the greatest names in jazz including Duke Ellington, Benny Goodman, and Chick Webb. ${ }^{236}$ Waller's religious father disapproved of Fats playing piano at school assemblies and of his performing ragged hymns. Fats disobeyed his father's request to end his worldly music pursuits, leading to fighting between the two. Their feud eventually took a toll on his mother health. To give his wife some peace, Waller's father

231 John S. Wilson, “The Cutting Sessions," in Reading Jazz: A Gathering of Autobiography, Reportage and Criticism from 1919 to Now, ed. Robert Gottlieb (New York: Pantheon, 1996), 399.

${ }^{232}$ Schuller, 225.

${ }^{233}$ Ibid., 225.

${ }^{234}$ Wilson, 395.

235 Jasen and Jones, 104.

${ }^{236}$ Dicaire, 105. 
allowed his fourteen year old son to drop out of school for one year to pursue a career as a musician in $1917 .^{237}$

After dropping out of school Waller took up a job as a delivery boy for a local delicatessen, and in his free time roamed the streets of Harlem exploring clubs and cabarets. His favorite place to visit was Lincoln Theater, a silent movie house on West 135 th Street. $^{238}$ Waller would meander down to the front row to watch the theater organist Maizie Mullins accompany the silent films. Eventually, she started allowing Waller to take her spot on the bench during her breaks. In 1919 Mullins left her job for health reasons and recommended that the fifteen year old Waller take her position. ${ }^{239}$ Around the same time Fats started his tenure at Lincoln Theater he won a talent contest after performing Johnson's Carolina Shout. Word started spreading around Harlem about Waller's tremendous talent. ${ }^{240}$

Fats' relationship with his father worsened considerably during the late 1910s. However, his mother, who had always shown particular favoritism towards Fats, stood by his musical ambitions. Unfortunately, his mother died in $1919 .{ }^{241}$ Her passing caused Waller's and his father's problems to escalate. Only sixteen years old, Fats decided to leave home. Fortunately, the family of Wilson Brooks, Fats' close friend, embraced Waller and brought him into their home. $^{242}$

Brooks's father, Russell, was a well-known local pianist. He nurtured Waller, taking him to rent parties to teach him the ins and outs of Harlem night life. In 1920 Russell introduced him to James P. Johnson, Waller's idol. After hearing Waller play, Johnson told his wife, "I know I

\footnotetext{
${ }^{237}$ Jasen and Jones, 104.

${ }^{238}$ Ibid., 104.

${ }^{239}$ Wilson, 395.

240 Jasen and Tichenor, 247.

241 Wilson, 395.

242 Jasen and Jones, 105.
} 
can teach that boy." From that point Johnson made Waller his protégé. ${ }^{243}$ Johnson first taught Waller how to make different layers of sound by using both hands. ${ }^{244}$ Through diligent practice and Johnson's guidance, Waller developed one of the strongest left hands in jazz. In fact, some of Fats' contemporaries said that strength of his left hand "could replace not only a rhythm section, but a whole band. ${ }^{245}$ Waller often practiced piano at Johnson's residence through the night and into the morning, until Mrs. Johnson ordered him to leave. ${ }^{246}$

Sometime in the early 1920s Johnson brought Fats to Leroy's to meet Willie "the Lion" Smith. Leroy's had a high dress standard and all of the patrons wore full-dressed suits or tuxedos. However, Fats strolled in with a wrinkled and greasy suit, the best he had. ${ }^{247}$ Johnson approached Smith and asked if Fats could play a few numbers. Smith gave Johnson and Waller his typical unfriendly reply saying: "I can't be bothered listening to some punk kid. Get that guy down because he looks filthy. Get them pants pressed. There's no excuse for it." ${ }^{248}$ However, Johnson persisted in asking Smith to allow Waller to play. Eventually, Smith left the piano stool and allowed the nervous kid his chance. Fats played a few tunes while Smith walked around Leroy's acting conspicuously inattentive. Then Fats started playing Johnson's Carolina Shout which finally grabbed "the Lion's" undivided attention. ${ }^{249}$ Smith told Johnson, "Watch out, Jimmy, he's got it. He's a piano-playing cub!",250

In early 1921 Fats married Edith Hatchett despite the fact that he lacked the means to support her. The teenage couple moved into Edith's parents' home. Her father demanded that

${ }^{243}$ Wilson, 396.

244 Dicaire, 105.

245 Joachim E. Berendt, The Jazz Book: From Ragtime to Fusion and Beyond, trans. Dan Morgeenstern and Tim Nevill (New York: Lawrence Hill Books, 1992), 223.

${ }^{246}$ Wilson, 396.

${ }^{247}$ Smith, 31.

248 Jasen and Jones, 106.

${ }^{249}$ Ibid., 106.

${ }^{250}$ Smith, 31. 
Fats take some responsibility and find some way to support Edith. He wanted Fats to end his musical ambitions and get a "man's" job. However, Fats decided he would prove that he could earn a living as a musician and started taking every piano job that came his way. He decided to leave Lincoln Theater to take a higher paying job at Lafayette Theater, got Lippy Boyette to help him with finding rent parties to play for, and substituted for Willie “the Lion” Smith at Leroy's for six weeks while Smith toured with a vaudeville act. Even though Fats had success in finding work, he never met the expectations of Edith's father. Fats eventually stopped going home in an attempt to avoid his father-in law. ${ }^{251}$

James P. Johnson and Clarence Williams continued to assist Fats with making connections and finding employment over the next two years. In 1922 Williams recommended Fats to the producers at OKeh, a recording company. Soon after, he made two solo piano tracks: Muscle Shoals Blues and Birmingham Blues. ${ }^{252}$ These two recordings did not sell well. However, OKeh executives raved over Waller's playing and hired him to collaborate and record for the blues singer Sara Martin. ${ }^{253}$ Later that year Johnson introduced Waller to the managers at the piano roll company QRS. By March of 1923 QRS decided to give Fats a shot, and at the end of the year he had made nine rolls of pop songs by several different artists. Williams purchased several of Waller's tunes in 1923, including Wild Cat Blues and Squeeze Me. ${ }^{254}$ Finally, Waller made his radio broadcasting debut in 1923 at the Fox Terminal Theater in Newark. He eventually started a series of regular appearances on WHN in New York. ${ }^{255}$

The rise of Waller's career hit a bump in 1923 when Edith decided to divorce him. Their settlement required that Waller make weekly payments of thirty-five dollars to support her and

\footnotetext{
251 Jasen and Jones, 107.

252 Ibid., 107.

253 Dicaire, 105-106.

254 Jasen and Jones, 108.

${ }^{255}$ Wilson, 396.
} 
their son. However, Waller often had trouble keeping up to this commitment making late, insufficient, or no payments at all. Even during the times when Fats made big money he would purposely neglect the obligations of his divorce settlement. Several times over the next twenty years Edith would have Fats arrested for not seeing to his financial responsibilities. ${ }^{256}$

Around the same time of his divorce Waller's friends started to show concern for his bottomless thirst for gin. Fats started drinking at clubs and rent parties when he dropped out of school. His colleagues noted that at recording sessions he had a quart on the piano and an additional one underneath the bench. Whenever Waller walked into a producer's office, he proceeded straight for the desk drawers, searching for a bottle of gin. Later in life when he toured with his band, he requested that his dressing room stay stocked with three bottles of whisky, two for himself and one for visitors. However, at the end of the day Waller usually had consumed the whole supply of whisky himself. ${ }^{257}$

Waller's lack of business skills, immaturity, and passion for booze often left him in desperate financial situations during the mid-1920s. When Waller found himself in the worst circumstances he would turn to his compositional talents to earn some money quickly. John S. Wilson, a jazz critic and broadcaster, recounts a specific time when Waller found himself in need of money:

There were times when it seemed as though composing was just as easy as breathing for Fats. There was one occasion when it was as easy as eating hamburgers. This was one early morning when he was out with Fletcher Henderson and some of the men in Henderson's band. They stopped in a hamburger joint where Fats quickly consumed nine specialties of the house. He was broke and he offered Henderson one tune per hamburger if he'd pick up the check. Henderson agreed and Waller called for manuscript paper. He quickly wrote out nine tunes and handed them over to Henderson who upped the price per tune from one hamburger to ten dollars. Waller's hamburger numbers included Top and Bottom (named after a Harlem drink made of wine and gin) which was later retitled Henderson Stomp, Thundermug Stomp which was changed to Hot Mustard, and other

\footnotetext{
256 Jasen and Jones, 109.

${ }^{257}$ Wilson, 397.
} 
tunes that were subsequently known as Variety Stomp, St. Louis Shuffle, and Whiteman Stomp. ${ }^{258}$

In 1924 Waller continued performing at Lafayette Theater while also taking a part-time job playing at Connie's Inn. While working at Connie's Inn he made a big impression on a press agent named George H. Maines, who Fats eventually hired as his manger. Maines had Waller audition at the Kentucky Club, a showcase for black talent, hoping the venue would help him gain exposure outside of Harlem. After working at the Kentucky Club for a few months Fats took a job playing with Louis Armstrong at the Hotel Sherman in Chicago. ${ }^{259}$

Fats returned to New York in 1926, at which point Maines pushed for Victor records to sign Waller to a contract. Victor denied their request. However, Ralph Peer, Victor's A\&R man, thought that a disc of jazz organ solos would sell well on the race market. Victor allowed Peer to try his idea, and in November of that year Waller made a two-sided disc. He returned to Victor on several occasions in 1927 to make organ recordings. The public never embraced Waller's organ recordings and in late 1927 Victor shut down Peer's experiment. ${ }^{260}$

One of Waller's most interesting recording sessions, from a musical perspective, occurred during the Peer recordings. Under the stern eye of officials from RCA-Victor, he recorded two fugues by Bach, Moszkowski’s Spanish Dance No. 1,' Liszt's Libestraum, Rimsky-Korsakov's Flight of the Bumble Bee, and Friml's Spanish Days. He played these tunes straight and then dressed them up in a hot treatment. Unfortunately, RCA-Victor never released these recordings. ${ }^{261}$

Waller had more than a casual interest in the organ. In fact, he could have made an excellent living playing solely on that instrument. Waller constantly sought out opportunities to

258 Ibid., 398.

259 Jasen and Jones, 110-111.

${ }^{260}$ Ibid., 111-113.

${ }^{261}$ Wilson, 394. 
play the organ. For example, Fats played the organ at the Cathedral of Notre Dame when he traveled to Paris in 1932. On another occasion, Waller held up the production of Stormy Weather for three hours while entertaining the entire production cast. Whenever Waller traveled to Chicago, a local musical instrument store sent a Hammond organ to his hotel room, compliments of the house. Regarding Waller's passion for the organ, the jazz critic Ashton Stevens said: "the organ is the instrument of his heart, the piano of his stomach."262

Waller relocated to Chicago in 1927 to perform in Erskine Tate's "Vendome Theatre Orchestra" with jazz stars Johnny Dodds, Baby Dodds, and Louis Armstrong. ${ }^{263}$ Not long after Waller had settled in Chicago, Edith had him arrested and brought back to New York to face alimony charges. The judge had Waller released after lecturing Waller on the consequences he would face if he continued to neglect his financial responsibilities. ${ }^{264}$

Waller teamed up with James P. Johnson and the lyricist Andy Razaf in February of 1928 to write the musical revue Keep Shufflin'. ${ }^{265}$ During the show's intermission Johnson and Waller performed stride from the orchestra pit. ${ }^{266}$ In April of 1928 Waller made his solo piano debut, performing Johnson's Yamekraw at Carnegie Hall. ${ }^{267}$ A few months later Waller moved to Philadelphia and started playing organ for silent films at the Philadelphia Grand Theater. He returned to New York in October of 1928. Soon after he returned, Edith had him arrested yet again. This time the judge sentenced Waller to six months in prison. ${ }^{268}$

\footnotetext{
262 Ibid., 394.

${ }^{263}$ Dicaire, 107.

264 Jasen and Jones, 113.

265 Dicaire, 107.

266 Jasen and Jones, 114.

${ }^{267}$ Dicaire, 107.

268 Jasen and Jones, 114.
} 
In 1929 Peer set up a series of three recording sessions at the Victor studio for a small band that included Waller and Eddie Condon. ${ }^{269}$ They called the group Waller's "Buddies," and were one of the earliest interracial bands to record. ${ }^{270}$ Waller also recorded a number of his best stride solos at these sessions including, Numb Fumblin, Handful of Keys, Gladyse, Valentine Stomp, Ain't Misbehavin, Sweet Savannah Sue, Smashing Thirds, and Goin' About. ${ }^{271}$

Waller continued his collaboration with Razaf in 1929. The duo produced a number of major hit songs such as Ain't Misbehavin, and What Did I Do To Be So Black and Blue from the stage show "Connie's Hot Chocolates" and Honeysuckle Rose from the revue "Load of Coal.,"272 For unknown reasons, Razaf and Waller sold the copyright for "Hot Chocolates" to Mills Music for a flat fee of $\$ 500$. If they had held on to the rights of "Hot Chocolates," they would have made a large sum of cash. However, Waller soon found himself broke and searching for ways to make money. ${ }^{273}$

In 1932 Waller made a brief trip to Paris with songwriter Spencer Williams. Upon his return he hired Phil Ponce as his new manager. During the depression musicians struggled with unemployment. However, the radio provided a few lucky artists with a chance to make some money. ${ }^{274}$ Fortunately, Ponce helped Waller land a spot as a radio musician at WLW in Cincinnati. While on the staff at WLW, Waller had his own late night radio showed called Fats Waller Rhythm Club on which he sang and played stride. He also played quiet and peaceful

${ }^{269}$ Ibid., 114.

${ }^{270}$ Alyn Shipton and Bill Dobbins, "Waller, Fats." In Grove Music Online. Oxford Music Online (accessed May 15, 2012), <http://www.oxfordmusiconline.com/subscriber/article/grove/music/48692>

\footnotetext{
${ }^{271}$ Jasen and Jones, 116.

${ }^{272}$ Shipton and Dobbins.

273 Jasen and Jones, 116.

${ }^{274}$ Dicaire, 108.
} 
organ music for an early morning program after he finished Fats Waller Rhythm Club. Waller savored the opportunity to play organ for a large listening audience. ${ }^{275}$

Waller returned to New York in 1934, and soon Ponce helped him land his first recording contract with Victor Records. ${ }^{276}$ He created a five-piece band called "Fats Waller and his Rhythm" to take to the recording studio. The personnel consisted Charlie Turner on bass, Al Casey on guitar, Herman Autry on trumpet, Gene Sedric on tenor saxophone, and Slick Jones on drums. 277 "Fats Waller and His Rhythm" recorded over a hundred times and frequently toured the country. ${ }^{278}$

Waller made his last set of major solo piano recordings in 1934. Under the Victor label he recorded African Ripples, Clothes Line Ballet, Alligator Crawl, and Viper's Drag. ${ }^{279}$ He then shifted his focus towards producing vocal recordings. Waller did not possess the same level of vocal talent that he did for the keyboard. However, his jovial personality and showmanship made his singing entertaining. Notable vocal tracks that he made in the mid-1930s include Dallas Blues, Garden City Blues, and I'm Crazy about My Baby. ${ }^{280}$

As Waller's fame continued to grow in the mid-1930s he took on an increasingly hectic schedule. He spent some time in California, appearing in two Hollywood films- Hooray for Love! and King of Burlesque- and playing at the West Coast branch of the Cotton Club with Les Hite's band in Culver City, California. ${ }^{281}$ Additionally, he continued working as a collaborative

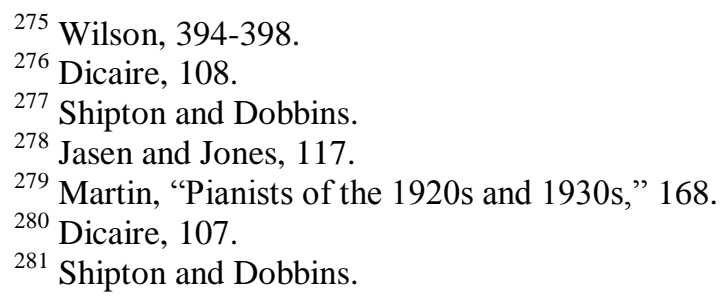


pianist with countless top jazz musicians and bands, including Jack Teagarden, Fletcher Henderson, Ted Lewis, Billy Banks’ Rhythmakers, and McKinney’s Cotton Pickers. ${ }^{282}$ Waller made two tours to England in the late 1930s to promote his music on an international level. While on his second trip he wrote an extended series of six related compositions for solo piano titled London Suite. ${ }^{283}$ Like James P. Johnson, Waller desired to bring his love for classical music to the public and desperately wanted recognition as a composer of serious compositions. Gene Sederic, a musician in Waller's little band said, "There were times when Waller was so full of his feeling for serious music that he couldn't help playing, even in a nightclub, with all the musicality of which he was capable." However, the public often rejected Waller's serious music, leaving a heavy burden in his heart. ${ }^{284}$

The American Federation of Musicians ban on recording in 1942 halted Waller's prolific career as a studio artist. ${ }^{285}$ The rise of recorded music had put many musicians, such as silent film accompanists, out of work. The president of AFM had tried to bargain with record company executives, asking that they share their profits so that the organization could support its unemployed musicians. After failing to reach an agreement, the organization required its members not to record for eighteen months. Since he was a member of the AFM, this temporarily stopped Waller's studio recording. ${ }^{286}$

As a result, Waller undertook an exceptionally heavy touring load during the 1940 s, performing at major venues for jazz such as Yacht Club, Famous Door, and the Apollo Theater in New York and at Hotel Sherman in Chicago. ${ }^{287}$ In 1943 he traveled to Hollywood to make the

\footnotetext{
${ }^{282}$ Dicaire, 107.

283 Jasen and Jones, 117-118.

${ }^{284}$ Wilson, 393.

285 Dicaire, 108.

286 Peretti, 88.

${ }^{287}$ Dicaire, 108.
} 
film Stormy Weather with Lena Horne and Bill Robinson, and collaborated on the show Early to Bed with the lyricist George Marion. ${ }^{288}$ Waller's health deteriorated quickly in late 1943 due to overdrinking, overeating, stress from legal troubles, and fatigue from touring. ${ }^{289}$ In December of 1943 Waller contracted pneumonia while performing in Hollywood. ${ }^{290}$ Soon after, he started a train trip back to New York to spend Christmas with his second wife and their two children. Unfortunately, he died on the train on December 15th. ${ }^{291}$

In short, there are several common trends in the lives of these four pianists. First, they all met individuals, such as Arthur Eck and Ernest Green, who stressed the importance of learning how to read music and understanding the fundamentals of music theory. These skills were critical in order to be successful in the highly competitive Harlem stride circuit. Second, each worked in musical theater during their careers. Through work in musical theater these pianists made professional connections and learned how to be well-rounded entertainers. Third, they all had an interest in writing extended compositions. Finally, each performed in premier New York concert halls such as Carnegie Hall. This demonstrates the level of talent each of these pianists possessed.

In the next two chapters the musical style and compositions of these four pianists is analyzed and examined.

\footnotetext{
${ }^{288}$ Shipton and Dobbins.

${ }^{289}$ Wilson, 400.

${ }^{290}$ Shipton and Dobbins.

291 Wilson, 400.
} 


\section{Chapter Three}

\section{Musical Characteristics of the Stride Style}

According to James P. Johnson's biographer Scott Brown, stride is a fusion of three musical genres: the ring shout, the blues, and ragtime. From the ring shout and other AfricanAmerican dance music, stride composers took call-and-response principles along with short repeated musical patterns. The use of blue (bent) notes, tone clusters, and improvisational concepts in stride came from the blues. Finally, stride's formal conventions, tonal and harmonic language, and textural elements are largely derived from ragtime. ${ }^{292}$ Each element is discussed further in this chapter.

Dances had a strong influence on the development of stride. ${ }^{293}$ When southern blacks moved to New York and other northern cities during the early twentieth century they brought their dance traditions with them, such as the ring shout and country dances. ${ }^{294}$ Many of the stride pioneers, including James P. Johnson, provided accompaniments for southern black dancers at “The Jungles Casino.” It was at venues such as “The Jungles Casino” that stride emerged. ${ }^{295}$ American music scholar Thomas L. Riis provides the following description of stride's emergence:

In such an environment, to take a strong, rhythmically clear and articulated approach was the only way for a pianist to be heard. Solid bass notes and high chords made a more resonant impression than notes clustered in the center of the keyboard, and that is exactly what Johnson's music contains.

\footnotetext{
${ }^{292}$ Henry Martin, "Balancing Composition and Improvisation in James P. Johnson's Carolina Shout," Journal of Music Theory (Fall 2005): 277-278.

293 Vinding and Fell, 2.

${ }^{294}$ Scott E. Brown and Robert Hilbert, James P. Johnson: A Case of Mistaken Identity, (Metuchen, NJ: The Scarecrow Press and the Institute of Jazz Studies, Rutgers University, 1986), 18.

${ }^{295}$ Dicaire, 60.
} 
Of course endurance was prized, and treating a straightforward chord progression to an extended series of variations, in stomp fashion, was bound to catch the attention of the dancing listeners. By playing tremolos, cross-rhythms, and rolled chords (instead of the expected oom-pahs), with harmonic variety and persistent melodic inventiveness, the Harlem stride players became legends. ${ }^{296}$

The ring shout, a semi-religious Negro dance, greatly influenced stride pianists. During a ring shout participants form a circle and walk counterclockwise in a shuffling manner keeping their feet close to the floor, snapping out intricate syncopations with their heels, and moving their bodies in jerking and hitching motions, particularly in the shoulders. ${ }^{297}$

During the nineteenth century ring shouts were most commonly practiced in the south, particularly in South Carolina and the Sea Islands of Georgia. ${ }^{298}$ James P. Johnson and many other stride pianists witnessed ring shouts during their youth. What they saw and heard at these dances had a tremendous influence on their piano playing. ${ }^{299}$ Willie "the Lion" Smith said:

Shouts are stride piano...just like the Baptist people sing. You don't just play a chord to that - you got to move it and the piano-players do the same thing in the churches, and there's ragtime in the preaching. Want to see a ring-shout? Go out to the Convent Avenue Baptist Church any Sunday. ${ }^{300}$

Stride pianists took a number of musical practices found in the ring and incorporated them into their compositions and performances. First, stride uses an inevitable steady pulse; phrase rubato was rare during stride performances. Second, the excitement and energy of the shout was imitated in stride through the use of fast tempos. Third, is the use of call-and-response devices. This is achieved on the piano through use of different registers. The preacher, who represents the "call," is played in higher registers while the congregation, who represents the "response" is played in the middle and lower registers [Ex. 3.1].

${ }^{296}$ Riis, 62.

${ }^{297}$ Samuel A. Floyd Jr., "Ring Shout! Literary Studies, Historical Studies, and Black Music Inquiry," Black Music Research Journal (Fall 1991): 268.

${ }^{298}$ Brown and Hilbert, 18.

299 Blesh and Janis, 190.

${ }^{300}$ Ibid., 188. 


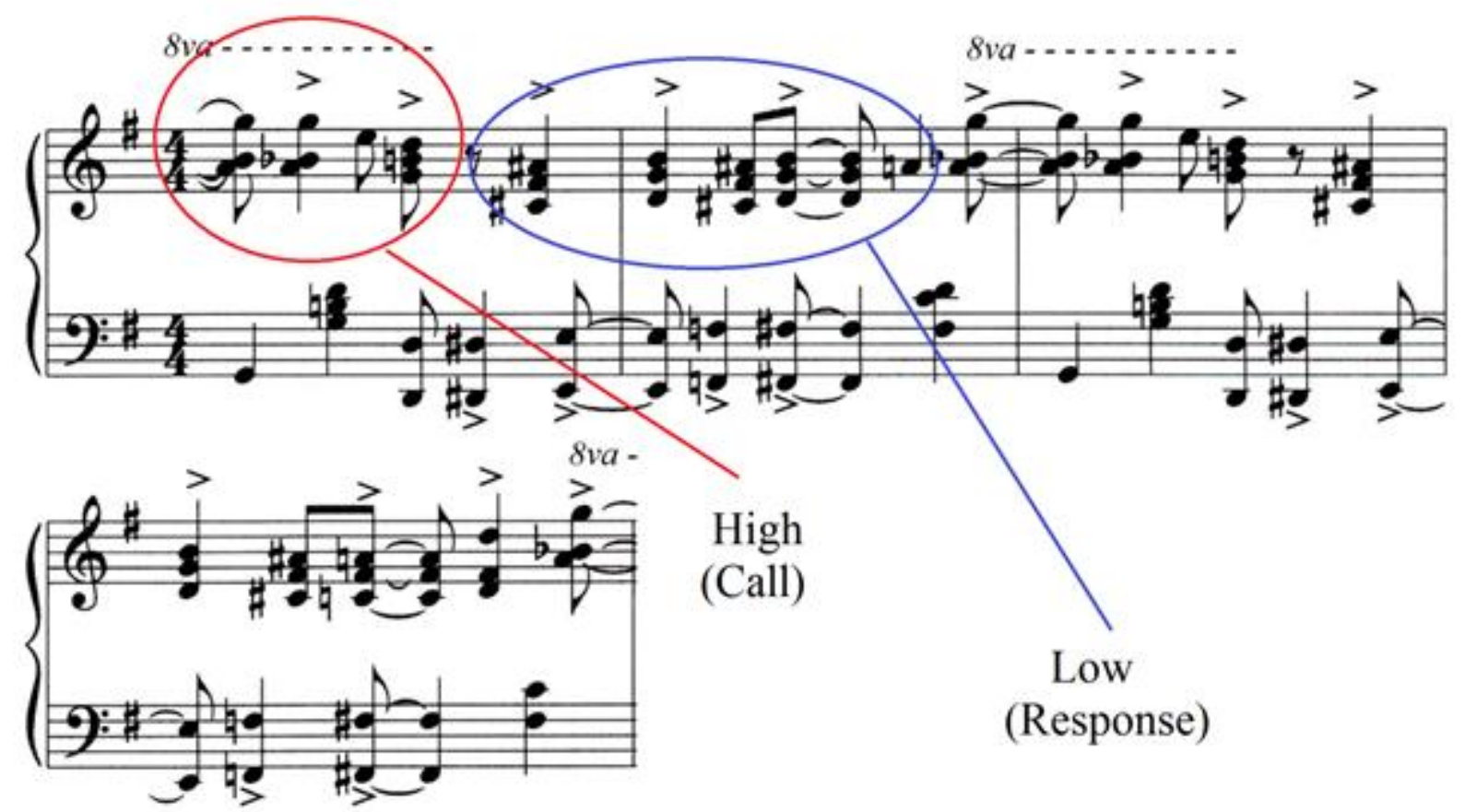

Example 3.1. Call-and-Response in James P. Johnson's 1944 Recording of Carolina Shout (mm. 54-57). Transcription by Riccardo Scivales.

Fourth, is the use of complex syncopations [Ex. 3.2]. The most complex syncopations usually occur in the right hand.

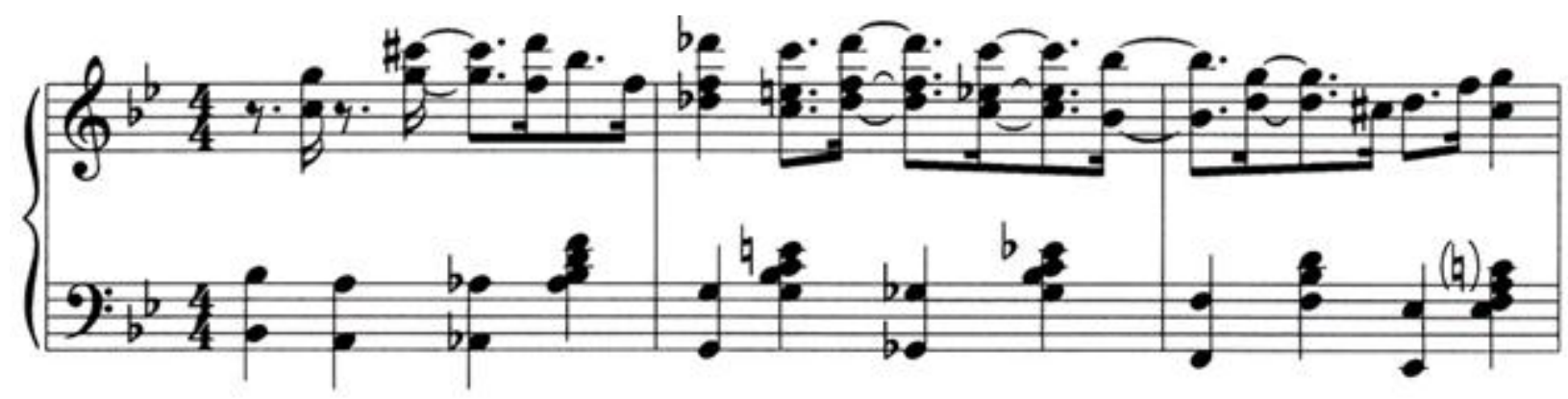

Example 3.2. Complex Syncopation in Fats Waller's 1929 Recording of Handful of Keys (mm. 81-83). Transcription by Paul Posnak. 
Finally, is the use of off-beat melodic lines [Ex. 3.3]. ${ }^{301}$

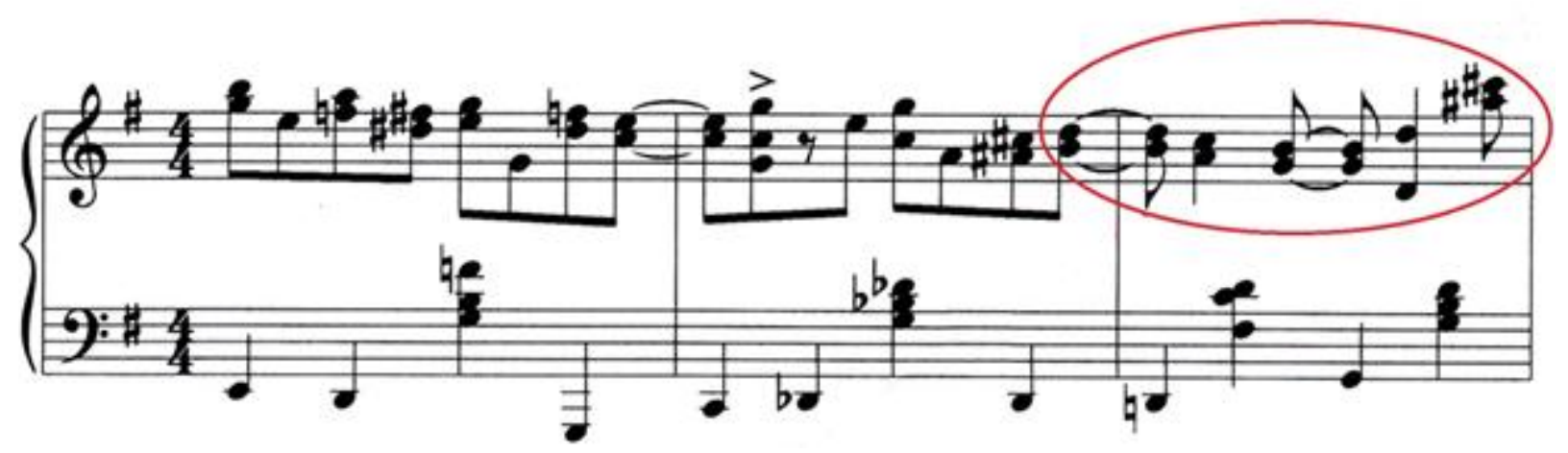

Example 3.3. Off-beat Melody in James P. Johnson's 1944 Recording of Carolina Shout (mm. 23-25). Transcription by Riccardo Scivales.

A second musical tradition that southern blacks brought with them when they migrated north was the blues. By the early 1910s many ragtime composers had started incorporating the blues into their compositions. The "Blues Craze" officially began in 1912 with the publication of W. C. Handy's Memphis Blues: a Southern Rag and peaked in popularity during the mid1920 s. $^{302}$ Since the blues craze coincides with the birth of stride, many stride performers integrated the blues into their playing. Furthermore, piano roll and record companies asked stride pianists to cut blues pieces and rent party audiences often requested bluesy tunes. ${ }^{303}$ Gunther Schuller theorizes that one of the reasons Johnson became so popular was that he incorporated various elements of the blues into his performances. ${ }^{304}$

There are several ways that stride composers and performers incorporated elements of the blues into their works. First, is the use of twelve-bar blues chord progressions (Table 3.1). The simple harmonic scheme of the twelve-bar blues chord progression was ideal for improvising

\footnotetext{
301 Floyd, 268.

302 Berlin, "Ragtime."

303 Scivales, 7.

${ }^{304}$ Scott E. Brown and Robert Hilbert, 57.
} 
and performing "tricks." 305 James P. Johnson used the twelve-bar blues chord progression in his Lonesome Reverie. ${ }^{306}$ Second, is the use of blue notes. ${ }^{307}$ Third, is the use of tone clusters or "crush" tones - two adjacent pitches played simultaneously to approximate the quarter-tone singing style of blues vocalists [Ex. 3.4]. ${ }^{308}$ Finally, stride players replicated the expressive and emotional qualities of the blues. This is achieved through use of wide dynamic ranges and a variety of articulations. $^{309}$

\begin{tabular}{|c||c|c||c||c||c||c|c|c||c||c||c||c||}
\hline $\begin{array}{l}\text { Measure } \\
\text { Number }\end{array}$ & $\mathbf{1}$ & $\mathbf{2}$ & $\mathbf{3}$ & $\mathbf{4}$ & $\mathbf{5}$ & $\mathbf{6}$ & $\mathbf{7}$ & $\mathbf{8}$ & $\mathbf{9}$ & $\mathbf{1 0}$ & $\mathbf{1 1}$ & $\mathbf{1 2}$ \\
\hline \hline Chord & $\mathrm{I}$ & $\mathrm{I}$ & $\mathrm{I}$ & $\mathrm{I}$ & $\mathrm{IV}$ & $\mathrm{IV}$ & $\mathrm{I}$ & $\mathrm{I}$ & $\mathrm{V}$ & $\mathrm{IV}$ & $\mathrm{I}$ & $\mathrm{I}$ \\
\hline
\end{tabular}

Table 3.1. Typical Twelve-bar Blues Chordal Progression.

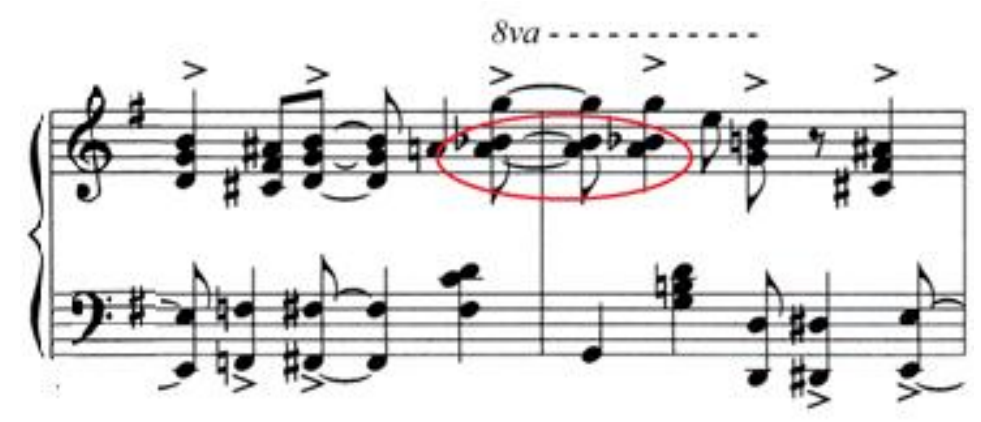

Example 3.4. "Crush” Tones in James P. Johnson's 1944 Recording of Carolina Shout (mm. 63-64). Transcription by Riccardo Scivales.

Ring shouts and the blues inspired stride pianists, but the most apparent influence was ragtime. Many stride composers used the rigid multi-sectional formal conventions of ragtime as the basis for their works. ${ }^{310} \mathrm{~A}$ typical stride composition consists of three to four independent

305 Scivales, 7.

${ }^{306}$ Ibid., 83.

${ }^{307}$ The blues scale is by no means absolute. However, the most common blues notes are lowered third, fifth, and seventh scale degrees. Gioia,13.

${ }^{308}$ Martin, "Balancing Composition and Improvisation," 278.

309 Brown and Hilbert, 128.

${ }^{310}$ Martin, "Pianists of the 1920s and 1930s," 165. 
sixteen-bar themes called strains. There are three different ways that stride composers typically arranged strains: (AABBACCC) as seen in James P. Johnson's The Mule Walk, (AABBCCDD) as seen in Luckey Roberts' Outer Space, and (AABBCCA) as seen in James P. Johnson's Lonesome Reverie. ${ }^{311}$ Furthermore, each strain has an extremely regular phrase structure that is typically divided into two-, four-, and eight-bar units. ${ }^{312}$

Most strain arrangements follow a predictable harmonic scheme. When stride compositions are in major modes, the first (A) and second (B) strains are in tonic, and the third (C) and fourth (D) strains, also known as the trios, are in subdominant. When a stride composition is in a minor mode, the first (A) strain is in tonic, the second (B) strain is in the relative major, and the third (C) and fourth (D) strains are in the subdominant of the relative major (Table 3.2). ${ }^{313}$

\footnotetext{
${ }^{311}$ Berlin, "Ragtime."

${ }^{312}$ Martin, "Balancing Composition and Improvisation," 278.

${ }^{313}$ Berlin, "Ragtime."
} 


\begin{tabular}{|c|c|c|c|c|c|c|c|c|}
\hline $\begin{array}{c}\text { Strain } \\
\text { Arrangement } \\
\text { No. } 1\end{array}$ & $\mathbf{A}$ & $\mathbf{A}$ & B & B & A & C & $\mathbf{C}$ & C \\
\hline $\begin{array}{c}\text { Key Area } \\
\text { (Major) }\end{array}$ & $\bar{I}$ & $\bar{I}$ & $\bar{I}$ & $\bar{I}$ & $\bar{I}$ & IV & IV & IV \\
\hline $\begin{array}{c}\text { Key Area } \\
\text { (Minor) }\end{array}$ & I & I & III (I) & III (I) & I & $\begin{array}{l}\text { b VI } \\
\text { (IV) }\end{array}$ & $\begin{array}{l}\text { b VI } \\
\text { (IV) }\end{array}$ & $\begin{array}{l}\text { b VI } \\
\text { (IV) }\end{array}$ \\
\hline
\end{tabular}

\begin{tabular}{|c|c|c|c|c|c|c|c|c|}
\hline $\begin{array}{c}\text { Strain } \\
\text { Arrangement } \\
\text { No.2 } \\
\end{array}$ & $\mathbf{A}$ & $\mathbf{A}$ & B & B & $\mathbf{C}$ & C & D & D \\
\hline $\begin{array}{c}\text { Key Area } \\
\text { (Major) } \\
\end{array}$ & I & I & I & I & IV & IV & IV & IV \\
\hline $\begin{array}{c}\text { Key Area } \\
\text { (Minor) }\end{array}$ & I & I & III (I) & III (I) & $\begin{array}{l}\text { b VI } \\
\text { (IV) }\end{array}$ & $\begin{array}{l}b_{\text {VI }} \\
\text { (IV) }\end{array}$ & $\begin{array}{l}\text { b VI } \\
\text { (IV) }\end{array}$ & $\begin{array}{l}\text { bVI } \\
\text { (IV) }\end{array}$ \\
\hline
\end{tabular}

\begin{tabular}{|c|c|c|c|c|c|c|c|}
\hline $\begin{array}{c}\text { Strain } \\
\text { Arrangement } \\
\text { No. } 3 \\
\end{array}$ & $\mathbf{A}$ & $\mathbf{A}$ & B & B & $\mathbf{C}$ & $\mathbf{C}$ & $\mathbf{A}$ \\
\hline $\begin{array}{c}\text { Key Area } \\
\text { (Major) }\end{array}$ & I & I & I & I & IV & IV & I \\
\hline $\begin{array}{c}\text { Key Area } \\
\text { (Minor) }\end{array}$ & I & I & III (I) & III (I) & $\begin{array}{l}\text { b VI } \\
\text { (IV) }\end{array}$ & $\begin{array}{l}\text { b VI } \\
\text { (IV) }\end{array}$ & I \\
\hline
\end{tabular}

Table 3.2. Strain Arrangements and Harmonic Schemes. 
There are a few ways that stride performers elaborated on this multi-sectional format. Often, stride composers wrote a four-bar introduction. A common performance practice was to substitute the composed introduction with an improvised one. Additionally, stride composers sometimes wrote four or eight-bar interludes before each trio ("C") section. ${ }^{314}$

The area where stride shows the most straightforward extension of ragtime is in the left hand bass patterns. ${ }^{315}$ In general, the left hand keeps a rigid and steady beat in both ragtime and stride. The most common left hand bass pattern employed in ragtime and stride is the "ommpah" accompaniment - a regular alternation of low bass notes or octaves on strong beats and mid-range chords on weak beats [Ex. 3.5]. ${ }^{316}$

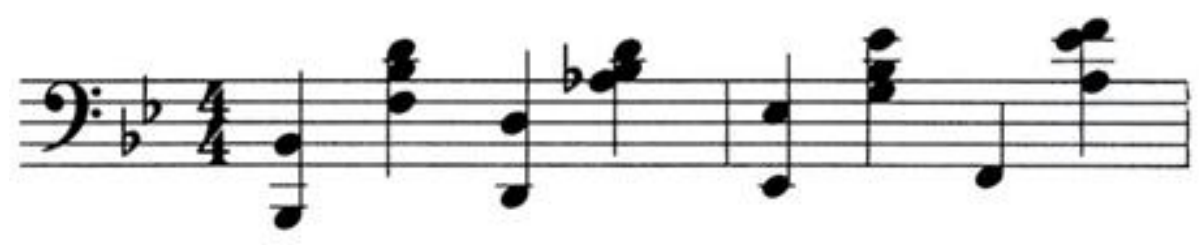

Example 3.5. "Omm-pah” in James P. Johnson's 1939 Recording of The Mule Walk (mm. 3-4) for Columbia Records. Transcription by Riccardo Scivales.

Early stride performers came up with a number of creative ways of varying the "ommpah." First, they added the option of playing a tenth on strong beats [Ex. 3.6]. ${ }^{317}$

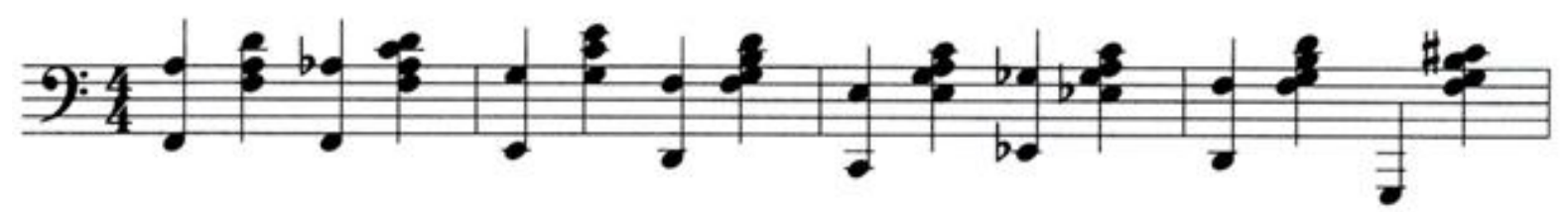

Example 3.6. Tenths Used on Strong Beats During an “Omm-pah” in Fats Waller's 1929 Recording of Smashing Thirds (mm. 54-57). Transcription by Paul Posnak.

\footnotetext{
314 Ibid.

315 Shipton, 131.

316 Berlin, "Ragtime."

${ }^{317}$ Vinding and Fell, 45.
} 
Second, compared to ragtime performers, stride pianists used wider leaps between the bass note and the succeeding chord [Ex. 3.7, see the difference between Scott Joplin and James P. Johnson]. ${ }^{318}$ The distance between the strong and weak beats in the "omm-pah" is called a "stride." The performer's technique and size of hand determined the distances a pianist could stride. Some Harlem pianists could stride a distance of a foot or longer at exceptionally fast tempos. $^{319}$

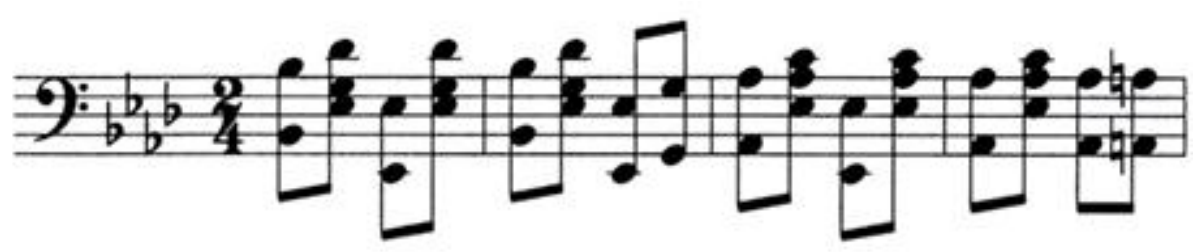

Example 3.7a. Compact “Omm-pah” in Scott Joplin’s Maple Leaf Rag (mm. 17-20).

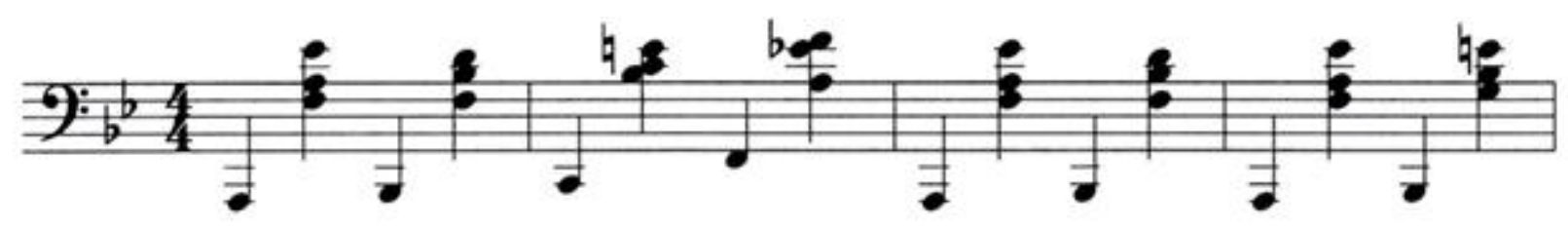

Example 3.7b. "Omm-pah" with Wide Leaps in James P. Johnson's 1939 Recording of The Mule Walk (mm. 7-10). Transcription by Riccardo Scivales.

Finally, stride performers occasionally reversed the "omm-pah" pattern so that the middle/upper chords occur on the strong beats and the single-notes, octaves, and tenths fall on the weak beats [Ex. 3.8]. The subsequent resumption of the normal "omm-pah" pattern creates intense rhythmic energy. ${ }^{320}$

\footnotetext{
${ }^{318}$ Riis, 60-61.

${ }^{319}$ Vinding and Fell, 45.

${ }^{320}$ Shipton, 131.
} 


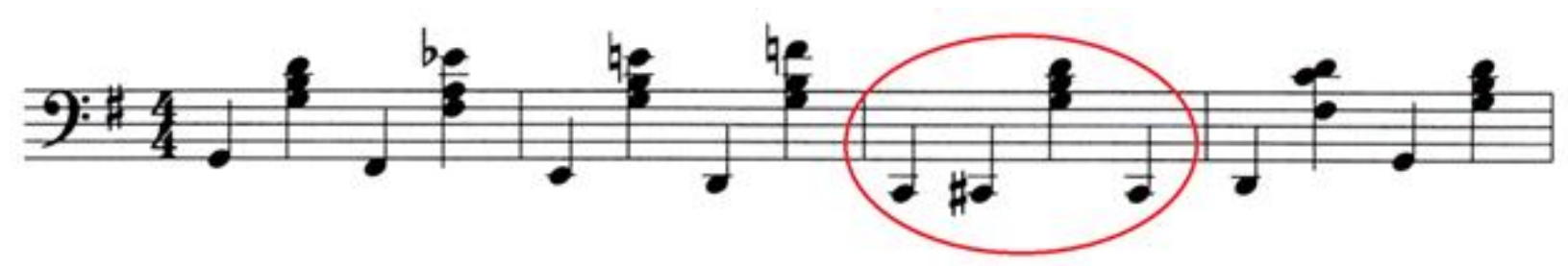

Example 3.8. Reversed “Omm-pah” in James P. Johnson's 1944 Recording of Carolina Shout (mm. 6-9). Transcription by Riccardo Scivales.

In addition to elaborating on the "omm-pah," stride pianists created and used a number of other left hand devices. First was the "backward" or "broken" tenth. ${ }^{321}$ In a "backward" tenth the upper note acts as a countermelody to the main tune and is played slightly before the lower (which carries the bass line) [Ex. 3.9]. ${ }^{322}$ The backward tenth creates a full sound and generates a sense of motion. ${ }^{323}$ Fats Waller made extensive use of the backward tenth.

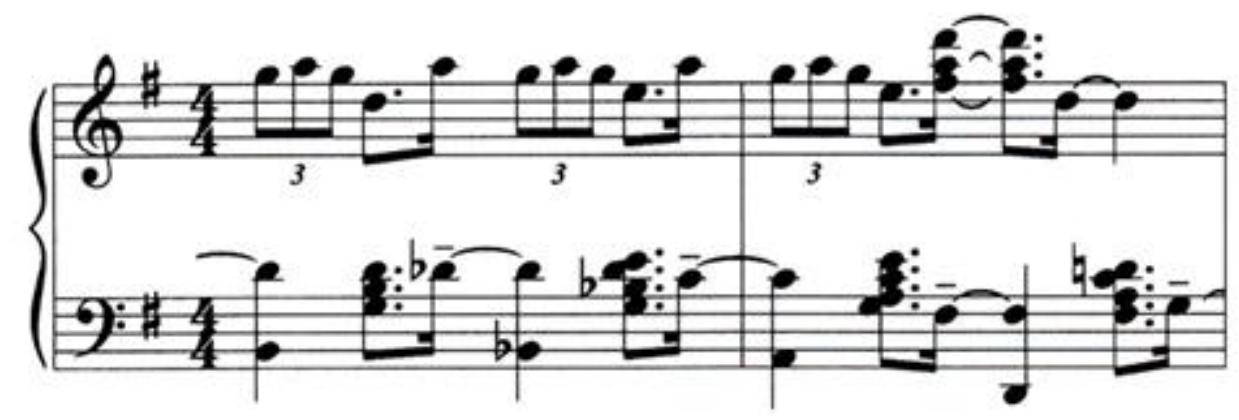

Example 3.9. Backward Tenths in Fats Waller's 1929 Recording of Gladyse (mm. 77-78). Transcription by Paul Posnak.

Second was the use of walking bass lines played in single notes, octaves, and sometimes in tenths [Ex. 3.10]. Walking bass lines tended to be anywhere from one to four measures in length.

\footnotetext{
${ }^{321}$ Ibid., 127-131.

322 Vinding and Fell, 46.

323 Shipton, 131.
} 


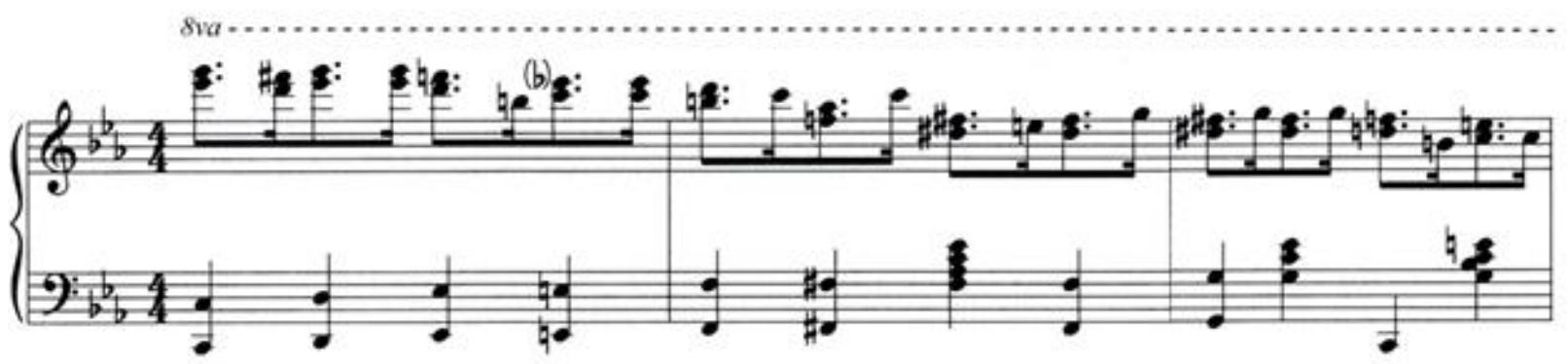

Example 3.10. Walking Bass Line in Fats Waller's 1929 Recording of Valentine Stomp (mm. 133-135).

Transcription by Paul Posnak.

Third, some pianists used boogie-woogie bass lines [Ex. 3.11]. ${ }^{324}$ However, most stride players would not admit to using boogie-woogie bass lines since this performance practice was thought to be inferior by stride performers. ${ }^{325}$

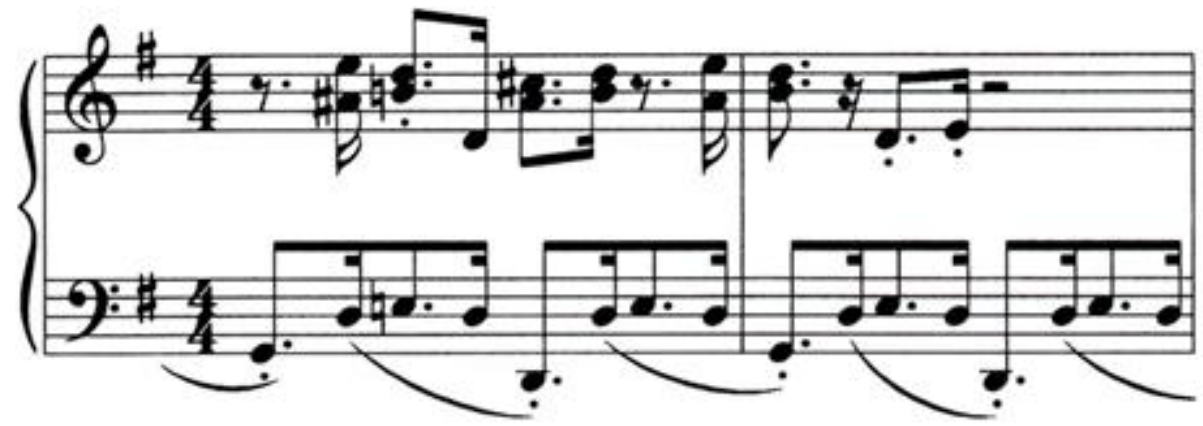

Example 3.11. Boogie-Woogie Bass Line in Waller's 1929 Recording of Numb Fumblin' (mm. 53-54). Transcription by Paul Posnak.

Finally, to a much lesser extent some stride players incorporated successive octaves, consecutive mid-range chords, and habanera- and tango-like syncopations into their compositions and performances [Ex. 3.12]. ${ }^{326}$

${ }^{324}$ In the boogie-woogie style the left hand plays a repeated bass pattern of single notes, usually one- to two-measures. Vinding and Fell, 45-47.

${ }^{325}$ Vinding and Fell, 45-47.

${ }^{326}$ Berlin, "Ragtime." 


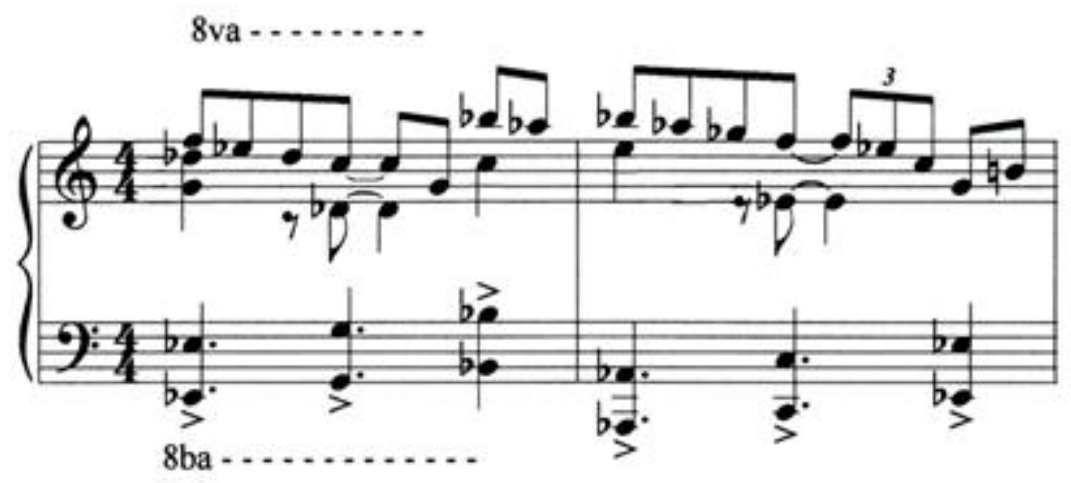

Example 3.12. Tango Rhythm (left hand) in James P. Johnson's 1944 Recording of Carolina Shout (mm. 150-151). Transcription by Riccardo Scivales.

Whereas left hand accompanimental figures of stride were clearly an extension of ragtime, stride right hand gestures are significantly different from ragtime's. ${ }^{327}$ Stride melodies were smooth and fluid whereas ragtime melodies were often jerky. ${ }^{328}$ According to the late stride pianist Dick Wellstood:

[T] he characteristic rhythms of stride are provided by the right hand, not the left. It is possible to play an otherwise impeccable stride bass and ruin it by playing inappropriate right hand patterns. By pulling and tugging at the rhythms of the left, the right hand provides the swing. ${ }^{329}$

Stride right hand melodies are almost exclusively based on short thematic ideas called "riffs" usually only two- or four-measures in length. ${ }^{330} \mathrm{~A}$ riff is repeated and varied several times within a strain [Ex. 3.13]. ${ }^{331}$ When a stride performer repeats a riff sometimes the pitches and rhythms are preserved and other times just the rhythm is maintained. ${ }^{332}$ Some of the ways that a

${ }^{327}$ Martin, "Pianists of the 1920s and 1930s," 165.

${ }^{328}$ Brown and Hilbert, 126.

${ }^{329}$ Dick Wellstood, liner notes, Donald Lambert: Harlem Stride Classics, Pumpkin Productions LP 104, 1977, long play, in Brown and Hilbert, 126.

${ }_{330}$ Martin, "Balancing Composition and Improvisation," 278-279.

331 Taylor, 63.

${ }^{332}$ Martin, "Balancing Composition and Improvisation," 278-279. 
stride performer varied riffs included playing them on the beat, off the beat, in thirds, in sixths, in different keys, ornamenting them, or adding arpeggiated figurations. ${ }^{333}$

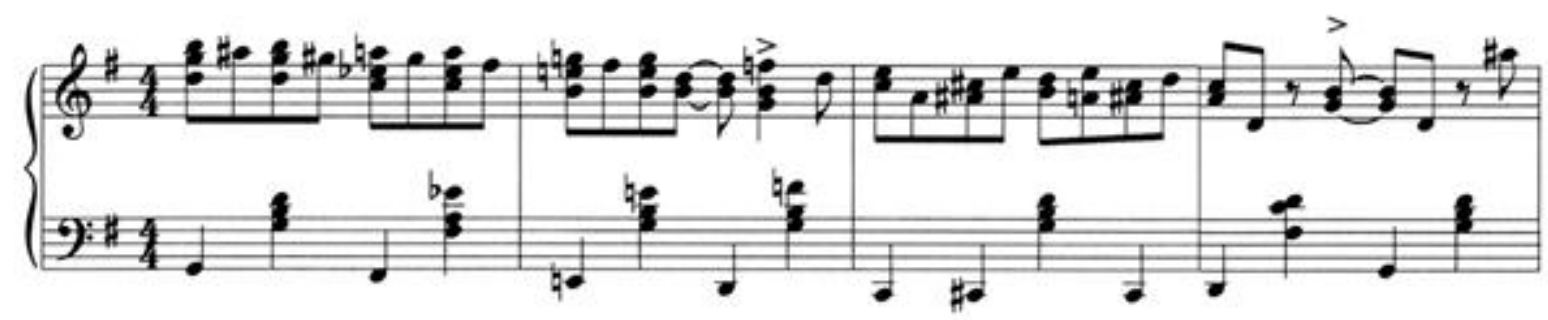

Example 3.13a. A Riff in James P. Johnson's 1944 Recording of Carolina Shout (mm. 6-9). Transcription by Riccardo Scivales.

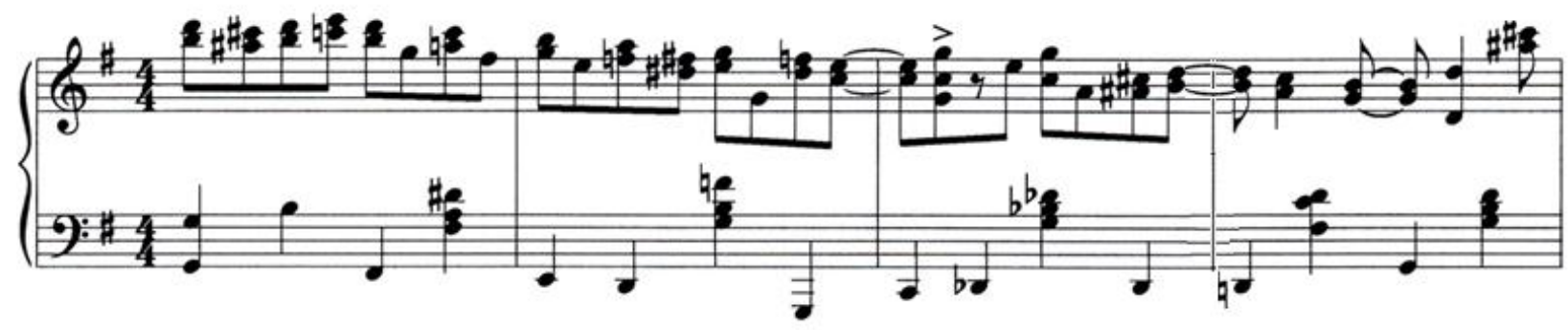

Example 3.13b. Johnson's Riff Varied (mm. 22-25).

A riff that is presented several times with little change is called a "groove" [Ex. 3.14], the genesis of which can be traced back to the ring shout. The groove is essential to James P. Johnson's style. Johnson's biographer states that dancers at "The Jungles Casino" reacted enthusiastically when he used grooves in his performances. Later styles of jazz and popular music, such as rhythm and blues as well as rock, make use of grooves. ${ }^{334}$

${ }^{333}$ Dick Wellstood, album notes, Donald Lambert: Classics in Stride, Pumpkin LP 110, 1980, long play, in Vinding and Fell, 48.

${ }^{334}$ Martin, "Balancing Composition and Improvisation," 286-287. 


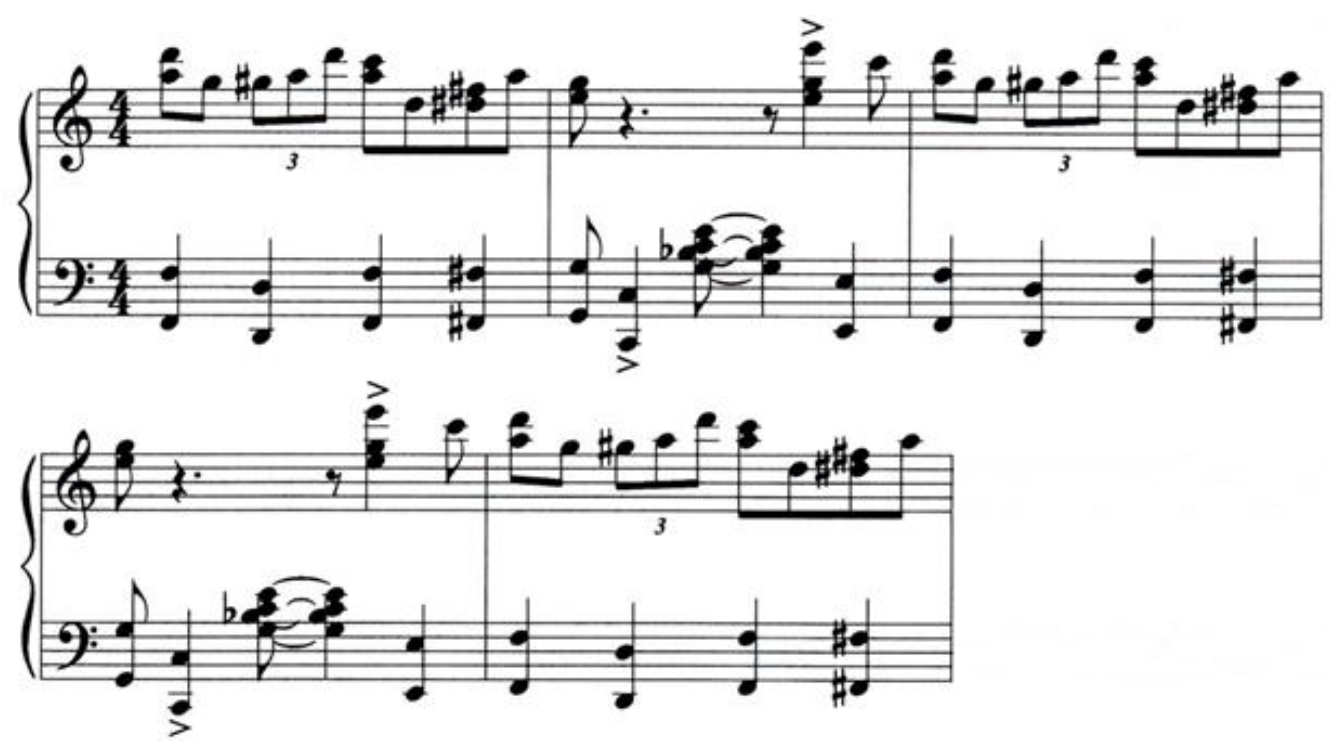

Example 3.14. A Groove in James P. Johnson's 1944 Recording of Carolina Shout (mm. 86-90). Transcription by Riccardo Scivales.

The riff- and groove-based melodies of stride were not conducive to free right hand improvisation. Additionally, performance challenges such as quick tempos, rapid harmonic changes, and difficult left hand accompanimental patterns discouraged many Harlem pianists from improvising. ${ }^{335}$ Therefore, most stride players worked out their music in advance instead of improvising. ${ }^{336}$ However, some stride players did not shy away from improvisation. Some of the more common ways stride pianists improvised was by adding arpeggios, blues notes, and melodic decorations. ${ }^{337}$ Since stride melodic ideas are largely based on riffs, many performers approached improvisation through rhythmic means rather than melodic. If a stride pianist did freely improvise, they usually waited until the trio(s) or over twelve-bar blues progressions. ${ }^{338}$

\footnotetext{
${ }^{335}$ Brown and Hilbert, 290-295.

${ }^{336}$ Ibid., 129.

337 Alioso, 20-21.

${ }^{338}$ Martin, "Balancing Composition and Improvisation," 290-295.
} 
Early stride pioneers established swinging eighth-notes, particularly in the right hand, as part of the stride style as early as the mid-1910s. ${ }^{339}$ One of the major problems that stride composers had with the swinging performance style was notating uneven eighth-notes. When playing swinging eighth-notes, the first eighth-note is held for roughly two-thirds of the beat and the second eighth-note is held for the final third of the beat. However, without an established system for notating swinging eighth-notes, most stride composers wrote either two eighth-notes or a dotted eighth-note followed by a sixteenth-note and left an indication at the beginning of the composition to swing. ${ }^{340}$

Pedaling in stride piano is not exact and varied from performer to performer and from recording to recording. According to jazz scholar Riccardo Scivales, stride performers avoided blurring of sounds when pedaling. ${ }^{341}$ One of the more common ways stride performers pedaled was once every two beats or once every four beats. However, in most cases stride composers did not indicate pedaling in their scores unless a specific affect was desired.

A final influence that ragtime had on stride was harmonic language. Stride performers and composers used the harmonic language of ragtime and expanded upon it in two ways. ${ }^{342}$ First, they frequently used extended harmonies such as ninth and thirteenth chords [Ex. 3.15]. ${ }^{343}$ Second, stride composers used a quicker harmonic rhythm than ragtime composers. ${ }^{344}$

\footnotetext{
339 Scivales, 17.

${ }^{340}$ Brown and Hilbert, 126.

341 Scivales, 17.

${ }^{342}$ Vinding and Fell, XV.

343 Taylor, 63.

${ }^{344}$ Martin, "Pianists of the 1920s and 1930s," 165.
} 


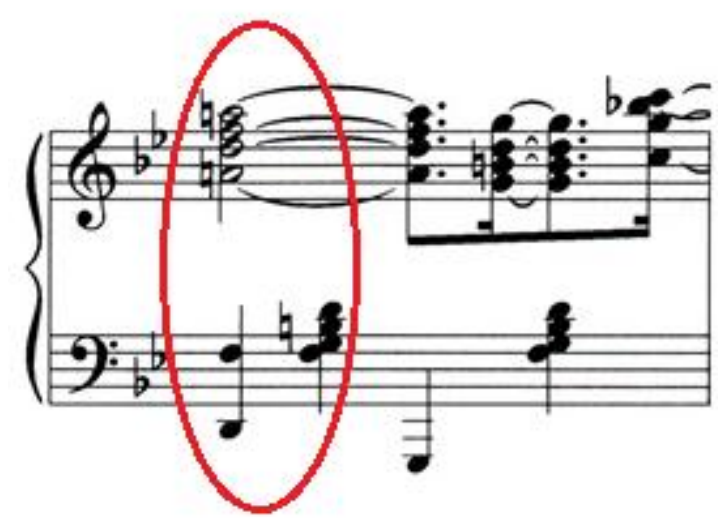

Example 3.15. Extended Harmony (added ninth) in Fats Waller's 1929 Recording of Handful of Keys (m. 104). Transcription by Paul Posnak.

All of the musical elements of stride discussed in this chapter are evident in the recorded works of Roberts, Johnson, Smith, and Waller. Each of these four individuals is noted for having remarkable left hand playing abilities: Roberts for his wide strides, Johnson and his creative variations on the "omm-pah," and Smith and Waller for their backward tenths. Johnson perfected the riff-and-variation melodic formula as demonstrated in his 1921 recording of Carolina Shout. The harmonic vocabulary of stride composers, especially Waller, was significantly more complex than in ragtime and jazz-influenced composers of the $1940 \mathrm{~s} .{ }^{345}$ In chapter four the specific stride devices discussed in this chapter are used to analyze four compositions/recordings by Roberts, Johnson, Smith, and Waller.

${ }^{345}$ Shipton, 127-133. 


\section{Chapter Four}

\section{Analysis}

In this chapter, transcriptions of Donald Lambert's ${ }^{1} 1961$ recording of Luckey Roberts' Pork and Beans ${ }^{2}$ by Paul Marcorelles, James P. Johnson's 1939 recording of The Mule Walk by Ricardo Scivales, Willie “the Lion” Smith’s 1949 recording of Cuttin' Out by Paul Marcorelles, and Fats Waller's 1929 recording of Handful of Keys by Paul Posnak are examined by applying the musical elements of stride discussed in chapter three. Each analysis includes information on the compositions/performances structure, melodic construction, and accompanimental patterns employed. The first piece analyzed is Pork and Beans.

Luckey Roberts published Pork and Beans on June 24th, 1913, and recorded the work in May of 1946. He named the composition after his favorite side dish. ${ }^{3}$ The structure of Roberts' 1913 publication is (Intro AABACDC), ${ }^{4}$ which is similar to "Typical Strain Arrangement No.1" (AABBACCC') as discussed in chapter three. ${ }^{5}$ In Lambert's recording he expands upon the structure of Luckey's 1913 publication (Intro AABACDC) by inserting a four-bar vamp ${ }^{6}$ after $^{2}$ the introduction [Ex. 4.1], inserting additional strains, and modifying the strain order (Intro, Vamp, $A^{1}, B^{1}, B^{2}, C^{1}, D^{1}, C^{2}, D^{2}, A^{2}, B^{2}, C^{3}$ ). Each strain is sixteen bars except $C^{3}$ which is extended by an extra measure (Table 4.1).

\footnotetext{
${ }^{1}$ Donald Lambert (1904-1962) often performed in Harlem clubs during the1930s. He was admired by Johnson and Waller. Lambert recorded only twice in his career, 1941 and 1961. Fell and Vinding, 135-138.

${ }^{2}$ Sheet-music of Luckey's 1913 publication of Pork and Beans is no longer available. Additionally, no transcriptions of his 1946 recording have been made.

${ }^{3}$ Jasen and Tichenor, 188 .

${ }^{4}$ Ibid., 188.

${ }^{5}$ See chapter three pages 56-58 for further information.

${ }^{6}$ Perhaps in cutting contests this vamp was repeated and used to perform "tricks."
} 


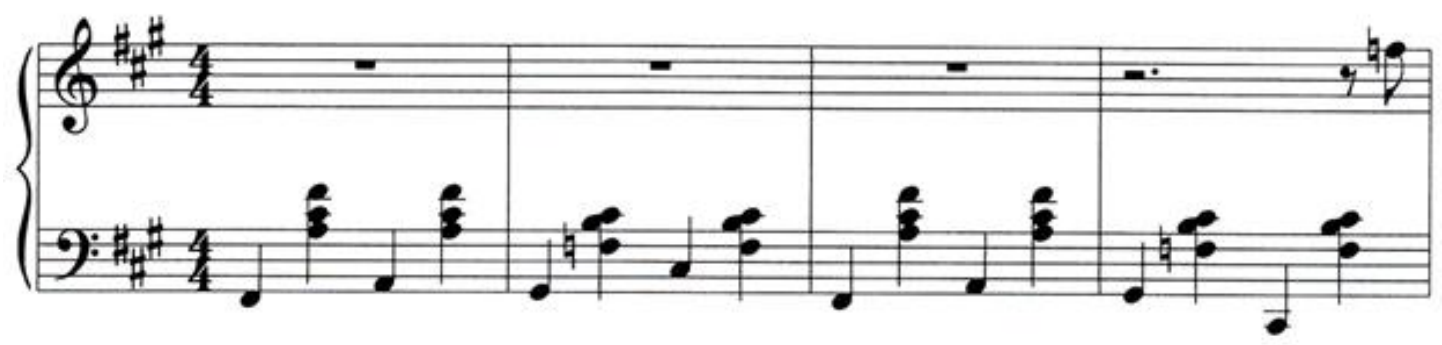

Example 4.1. Lambert's Vamp (mm. 8-11). ${ }^{7}$

\begin{tabular}{|c|c|c|c|c|c|c|c|c|c|c|c|c|}
\hline \multicolumn{10}{|c|}{ FORM } \\
\hline \hline Section: & Intro & Vamp & $\mathrm{A}^{1}$ & $\mathrm{~B}^{1}$ & $\mathrm{~B}^{2}$ & $\mathrm{C}^{1}$ & $\mathrm{D}^{1}$ & $\mathrm{C}^{2}$ & $\mathrm{D}^{2}$ & $\mathrm{~A}^{2}$ & $\mathrm{~B}^{3}$ & $\mathrm{C}^{2}$ \\
\hline \hline Measure & \multirow{2}{*}{$1-7$} & \multirow{2}{*}{$8-11$} & $12-$ & $28-$ & $44-$ & $60-$ & $76-$ & $92-$ & $108-$ & $124-$ & $140-$ & $156-$ \\
Numbers: & & & 27 & 43 & 59 & 75 & 91 & 107 & 123 & 139 & 155 & 172 \\
\hline \hline Key: & f\#m & f\#m & f\#m & f\#m & f\#m & F\#M & f\#m & F\#M & f\#m & f\#m & f\#m & f\#m \\
\hline
\end{tabular}

Table 4.1. Thematic Presentation in Lambert's 1961 Recording of Pork and Beans.

The harmonic scheme of Pork and Beans is unusual in that it does not follow the standard modulation pattern typically found in minor mode stride compositions. ${ }^{8}$ The entire piece is in $\mathrm{f}$ sharp minor except the "C" strains which modulate to the parallel major (F-sharp major). If Roberts had followed the typical harmonic scheme of a minor mode stride composition he would have modulated to the relative major (A Major) in the "B" strains and to the subdominant of the relative major (D Major) in the "C" and " $\mathrm{D}$ " strains.

The melody in the "A" and "C" strains of Pork and Beans is based on "riffs." In both the "A" and "C" strains an eight-beat riff is repeated three times and is followed by a two-measure "break" ${ }^{\prime 9}$ Ex. 4.2]. After the break the riff returns and is repeated twice. Both strains end with a four-measure break.

\footnotetext{
${ }^{7}$ No changes or alterations of the transcriber's notation were made in creating the examples for this chapter.

${ }^{8}$ See chart on page 57.

${ }^{9}$ In the following analysis,' a 'break" refers to a brief interruption, usually one or two bars, of the riff pattern.
} 

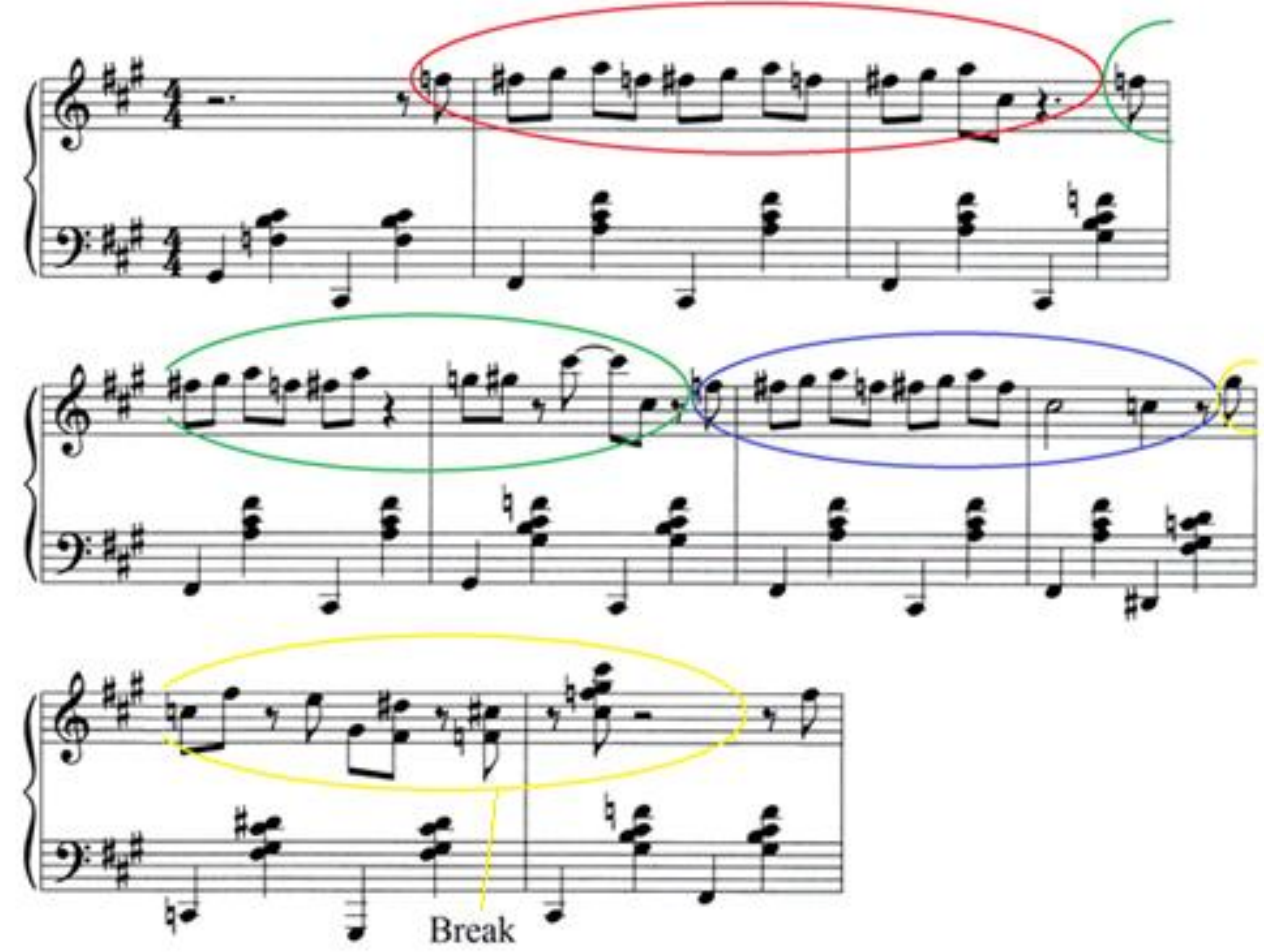

Example 4.2a. Pork and Beans "A” Strain Riffs (mm.11-19).
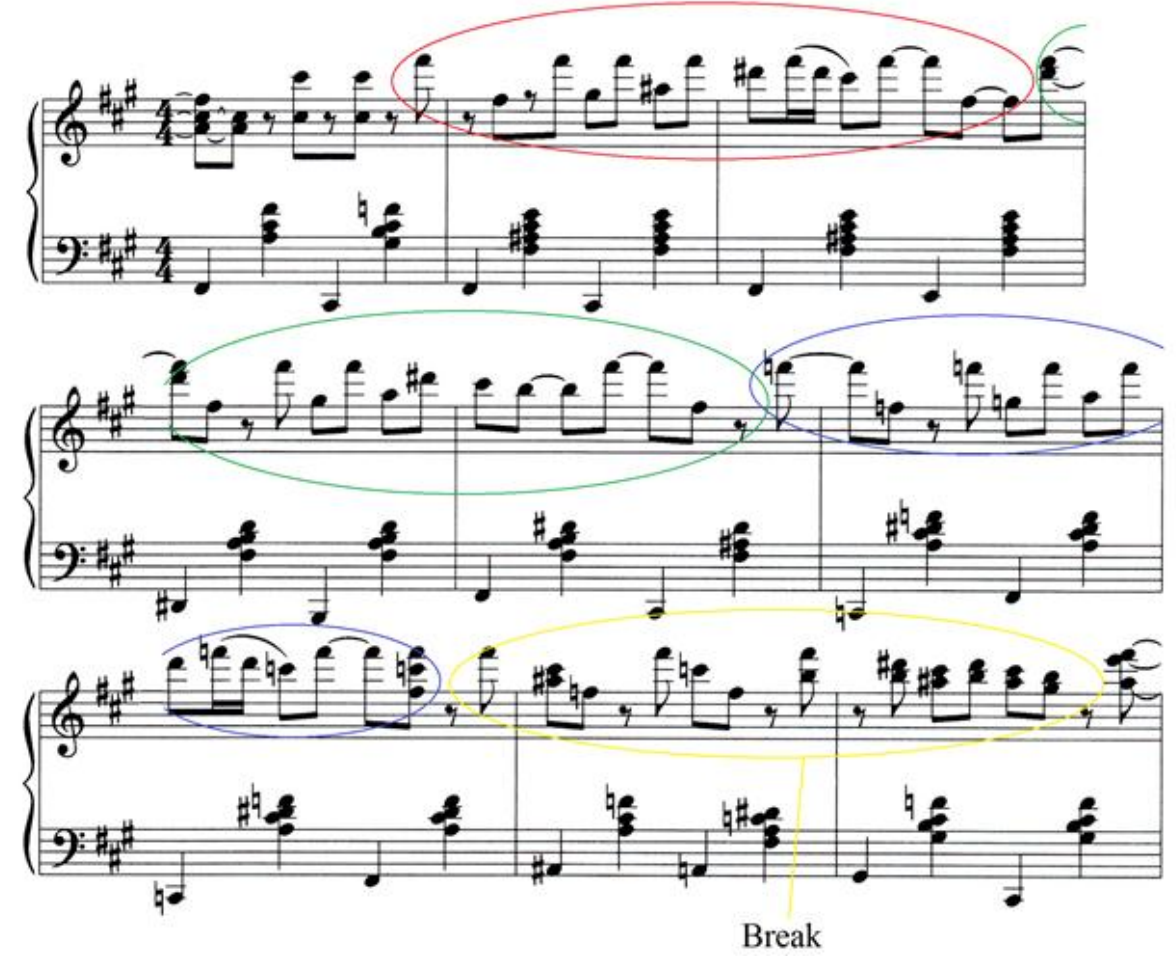
Example 4.2b. Pork and Beans "C" Strain Riffs (mm. 59-67).

The melody in the "B" and "D" strains of Pork and Beans are based on "grooves." The presentation and organization of the "B" and " $\mathrm{D}$ " strain grooves are the same as the " $\mathrm{A}$ " and "C" strains in that an eight-beat melodic and rhythmic idea is presented three times and is followed by a two-measure break [Ex. 4.3]. In the fourth measure of the "B" strain groove, Lambert plays a rising chromatic line before the final two chords (see highlighted circle in example 4.3a). Since the alteration is minimal it seems best to classify the melody in the "B" strains as a groove rather than a riff.

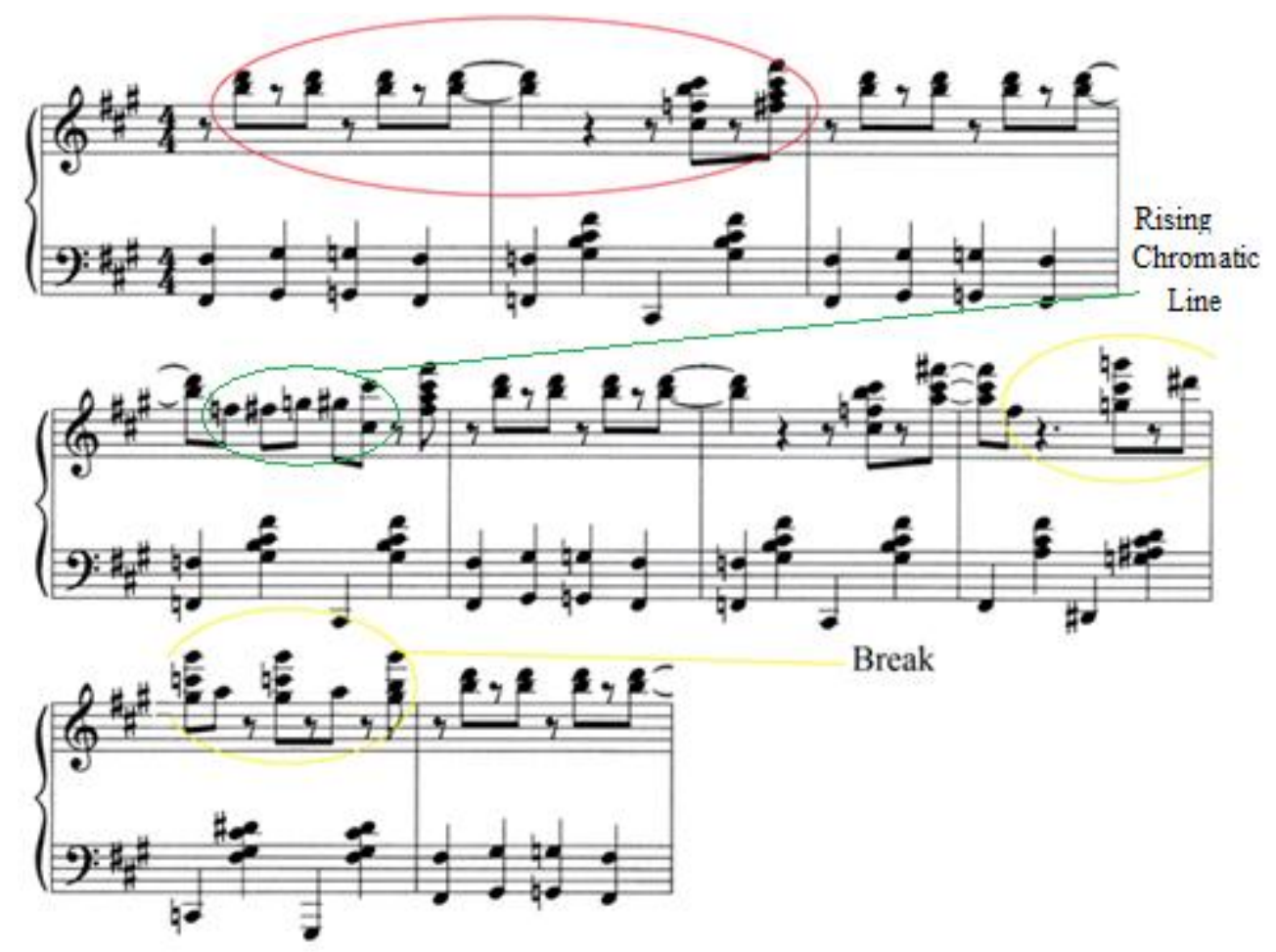

Example 4.3a. Pork and Beans "B" Strain Groove (mm. 27-35). 

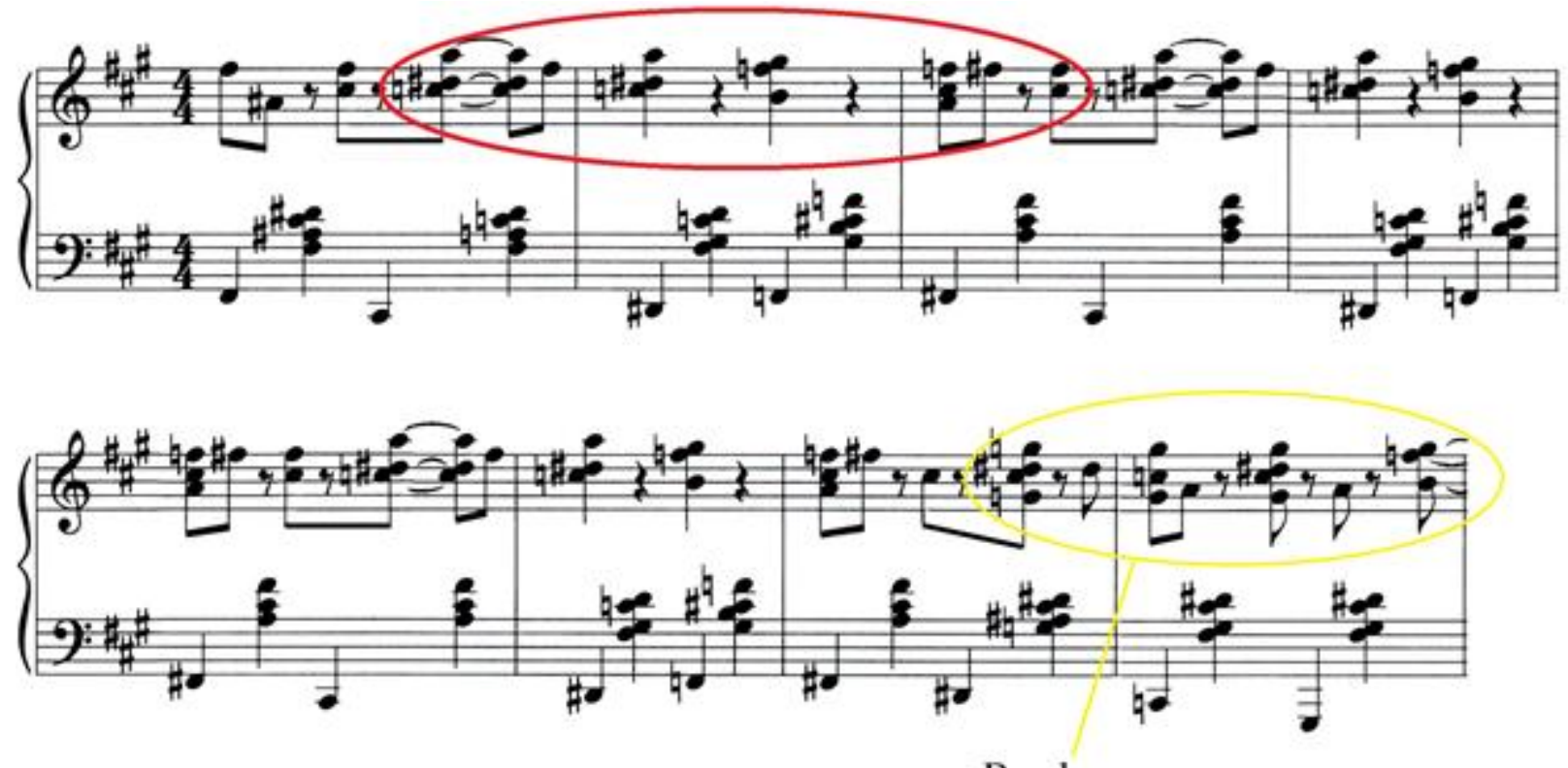

Break

Example 4.3b. Pork and Beans "D" Strain Groove (mm. 75-82).

There are two additional melodic traits in Pork and Beans that exemplify the stride style.

First, Roberts' melodies are on the anticipatory side, specifically, anacrusis [Ex. 4.4].

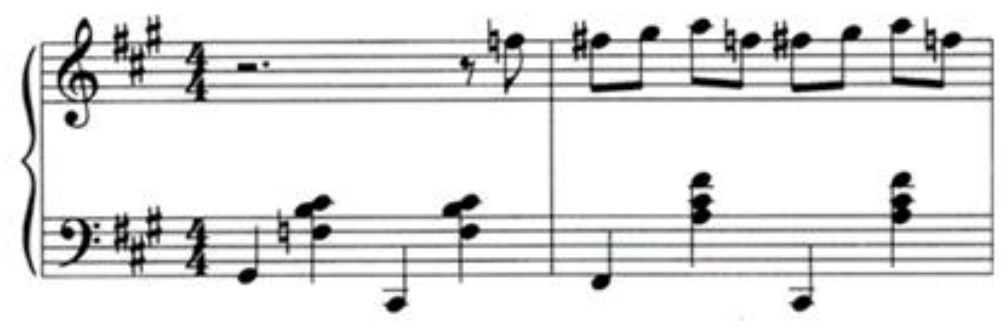

Example 4.4. Pork and Beans Anticipatory Melody (mm. 11-12).

Second, many of the melodies are syncopated [Ex. 4.5].

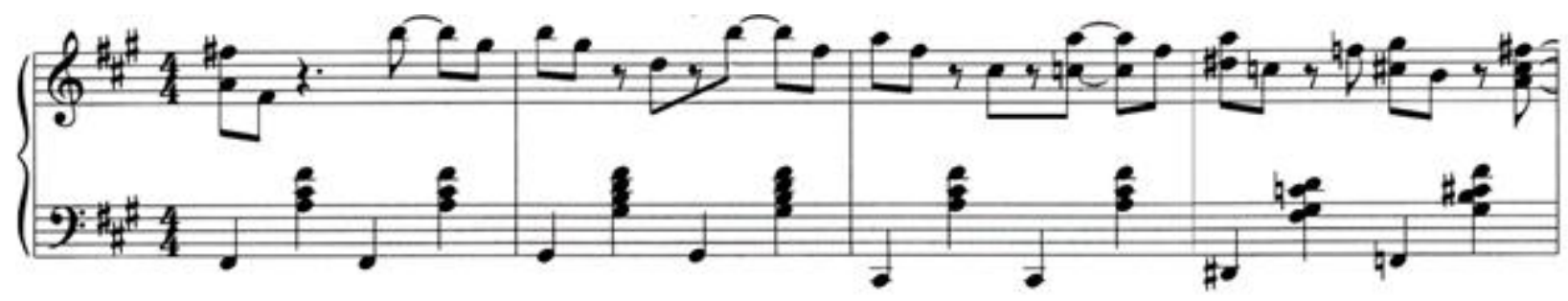

Example 4.5. Pork and Beans Syncopated Melody (mm. 55-58). 
The melodic construction of Pork and Beans is rooted in the stride style. However, the left hand accompaniment resembles that of ragtime rather than stride. Many of the sophisticated left hand stride techniques, such as back beating and backward tenths, are not used in Pork and Beans. Instead, Roberts/Lambert almost exclusively used the "omm-pah" throughout the entire composition/performance. The only non- "omm-pah" left hand stride device used in this composition/performance is the walking bass lines [Ex. 4.6].

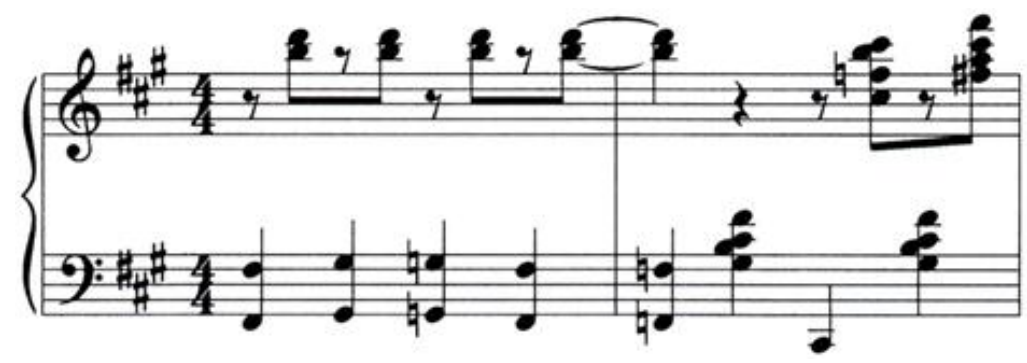

Example 4.6. Pork and Beans Walking Bass Line (mm. 35-36).

Another way that the left hand patterns in Pork and Beans resemble the ragtime style, rather than stride, is in the simplicity of the "omm-pah." Many of the "omm-pah" expansions of the stride style are not used in this composition/recording. First, Roberts/Lambert exclusively used single notes on the strong beats in the "omm-pah." Second, the left hand chord voicings are often repeated instead of varied [Ex. 4.7].

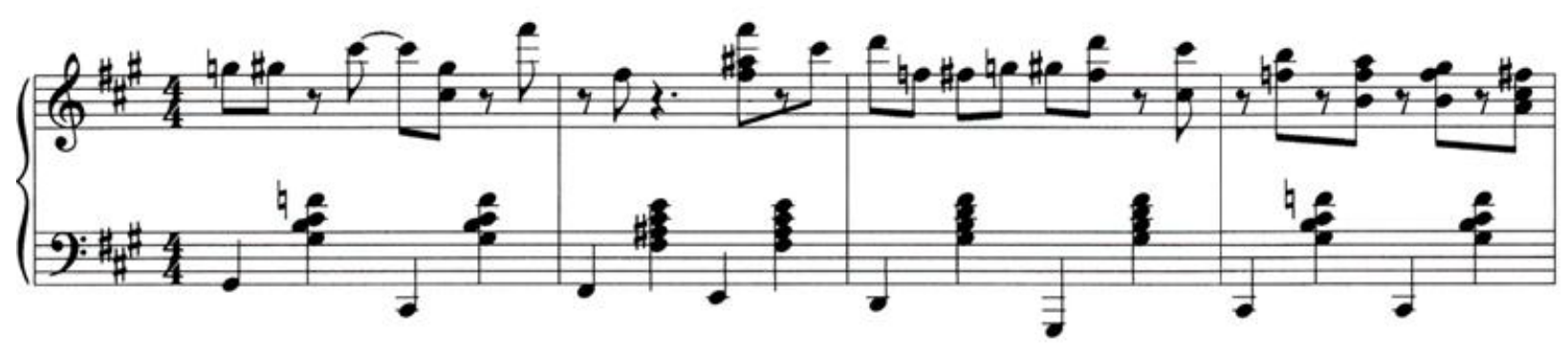

Example 4.7. Pork and Beans Repeated Chord Voicings (mm. 23-26). 
Finally, there are only a few instances when Roberts/Lambert used wide "strides" [Ex. 4.8].

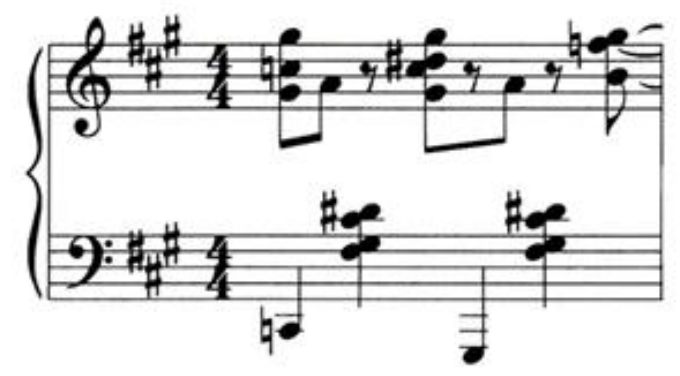

Example 4.8. Pork and Beans Wide Stride (m. 82).

Finally, Roberts incorporates elements of the ring shout in Pork and Beans. One of the most prominent instances occurs during the " $\mathrm{B}$ " strains when Roberts uses call-and-response [Ex. 4.9]. Roberts achieves this through changes of texture and accompaniment from one measure to the next. During the "call" the right hand plays a series of four off-beat harmonic thirds while the left hand has a chromatic walking bass line. For the "response" the right hand is melodic and the left hand plays an "omm-pah."

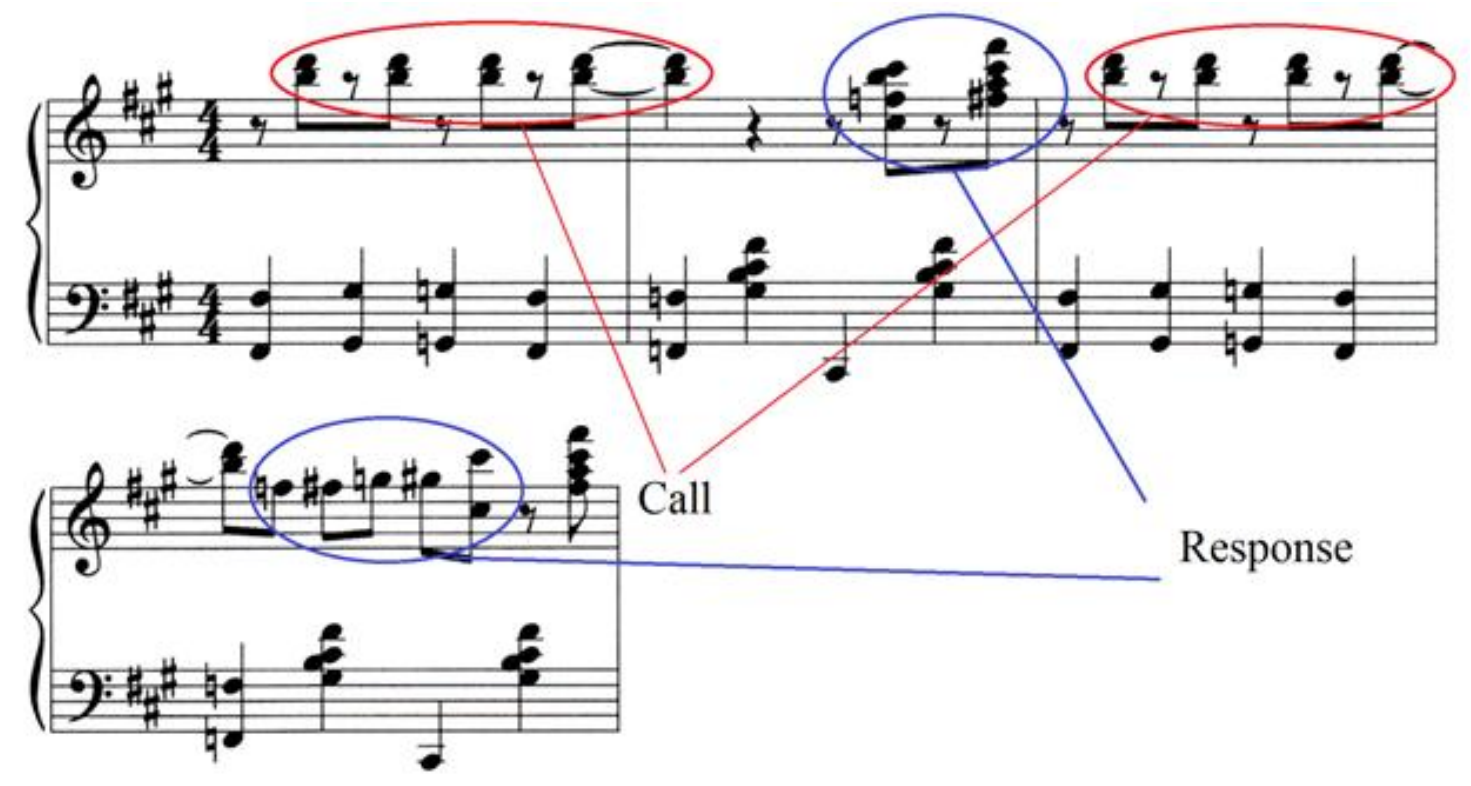

Example 4.9. Pork and Beans Call-and-Response (mm. 27-30). 
Although Pork and Beans (1913) was written when ragtime was still the dominant African-American musical entertainment in New York, the musical features in this composition are predominantly rooted in the stride style. First, the melodies are based on riffs and grooves. Second, the structure of the original publication of Pork and Beans has a typical strain arrangement, although Lambert alters and expands the formal organization in his recording. Third, Lambert performs Pork and Beans at a quick tempo, quarter note $=245$. Finally, Roberts and Lambert incorporate call-and-response into the composition/recording.

The one area where Pork and Beans resembles the ragtime style rather than stride is in the left hand accompaniment. In general, the left hand patterns in Pork and Beans are relatively simple compared to stride compositions and recordings of the 1920s and 1930s. Lambert's recording lacks sophisticated left hand stride techniques such as back beating, backward tenths, and large strides.

The next piece analyzed, James P. Johnson's The Mule Walk, was composed around 1913, the same year that Roberts wrote Pork and Beans. The inspiration for The Mule Walk was an old country dance set that Johnson saw while working at "The Jungles Casino." ${ }^{10}$ Johnson never published The Mule Walk. However, he recorded the work twice during his lifetime, first for Columbia Records in 1939 and later for the Blue Note label in 1943. ${ }^{11}$ The 1939 version is used in this analysis.

The thematic presentation and harmonic scheme in The Mule Walk is deeply rooted in the stride style in several ways. First, the structure of Johnson's performance is exactly the same as “Typical Strain Arrangement No. 1" (Intro, $\left.\mathrm{A}^{1}, \mathrm{~A}^{2}, \mathrm{~B}^{1}, \mathrm{~B}^{2}, \mathrm{~A}^{3}, \mathrm{C}^{1}, \mathrm{C}^{2}, \mathrm{C}^{3}\right){ }^{12}$ Second, the "A" and

\footnotetext{
${ }^{10}$ Scivales, 94.

${ }^{11}$ Jasen and Tichenor, 245.

${ }^{12}$ See chapter three, pages $56-58$, for further explanation.
} 
"B" strains are in B-flat major and the "C" strains are in the subdominant, E-flat Major. Finally, each strain is sixteen-bars (Table 4.2).

\begin{tabular}{|c||c|c|c|c||c|c||c|c||c||}
\hline \multicolumn{9}{|c|}{ FORM } \\
\hline \hline Section: & Intro & $\mathrm{A}^{1}$ & $\mathrm{~A}^{2}$ & $\mathrm{~B}^{1}$ & $\mathrm{~B}^{2}$ & $\mathrm{~A}^{3}$ & $\mathrm{C}^{1}$ & $\mathrm{C}^{2}$ & $\mathrm{C}^{3}$ \\
\hline \hline $\begin{array}{l}\text { Measure } \\
\text { Numbers: }\end{array}$ & $1-4$ & $5-20$ & $21-36$ & $37-52$ & $53-68$ & $69-84$ & $85-100$ & $\begin{array}{c}101- \\
116\end{array}$ & $\begin{array}{c}117- \\
132\end{array}$ \\
\hline \hline Key: & B-flat & B-flat & B-flat & B-flat & B-flat & B-flat & E-flat & E-flat & E-flat \\
\hline
\end{tabular}

Table 4.2. Thematic Presentation in Johnson's 1939 Recording of The Mule Walk. ${ }^{13}$

The melody in each strain of The Mule Walk is riff based. In Johnson's recording, he makes no significant alterations to each riff within a strain. However, he varies the rhythm and melodic ornamentation of each riff in subsequent strains. The " $\mathrm{C}$ " strain riff illustrates this [Ex. 4.10].

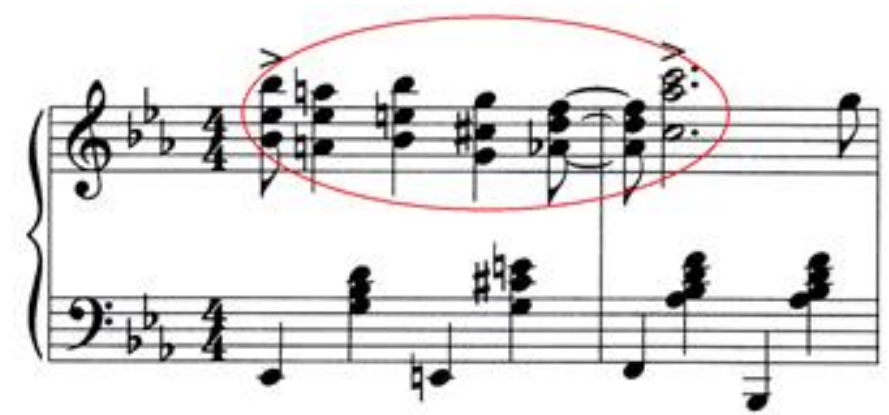

Example 4.10a. The Mule Walk "C $\mathrm{C}^{1 \text { " }}$ Riff (mm. 85-86).

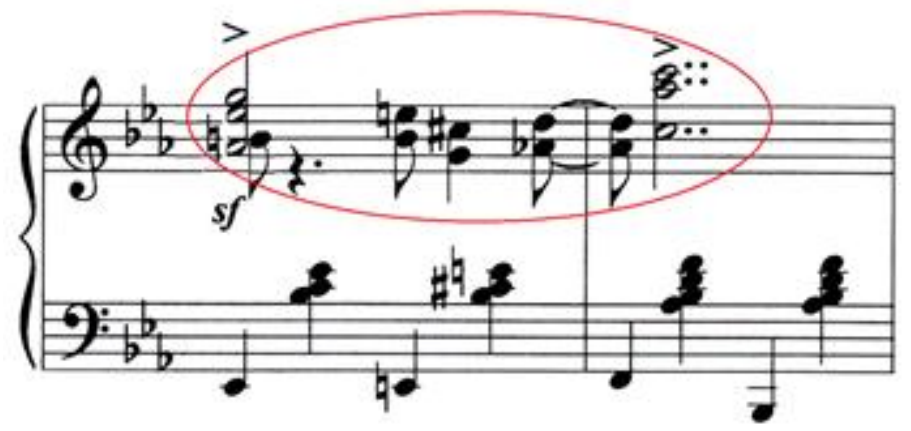

Example 4.10b. The Mule Walk "C $\mathrm{C}^{2 "}$ Riff, Rhythmic Variation (mm. 101-102).

\footnotetext{
${ }^{13}$ Scivales, 94.
} 
Johnson uses a variety of left hand accompaniments including many of the "omm-pah" expansions discussed in chapter three. The most frequently used accompaniment is the "ommpah." He often substituted single notes in favor of octaves on the strong beats of the "omm-pah" and many of his "omm-pah's" contain wide strides [Ex. 4.11].

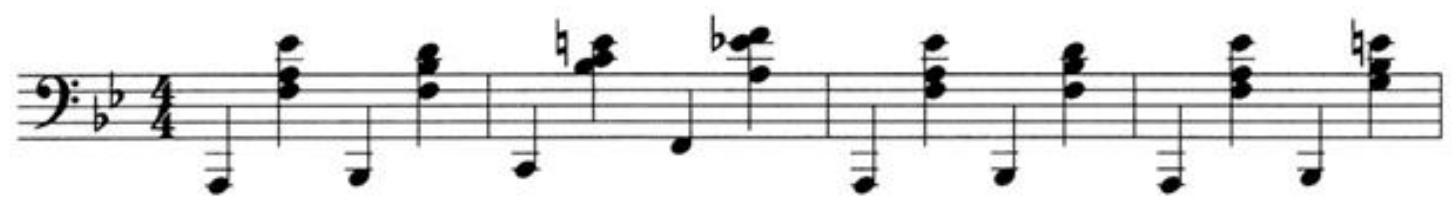

Example 4.11. The Mule Walk Wide Stride (mm. 7-10).

Also, there are a few instances when Johnson played walking bass lines, most notably during the "A" and "C" strains [Ex. 4.12].

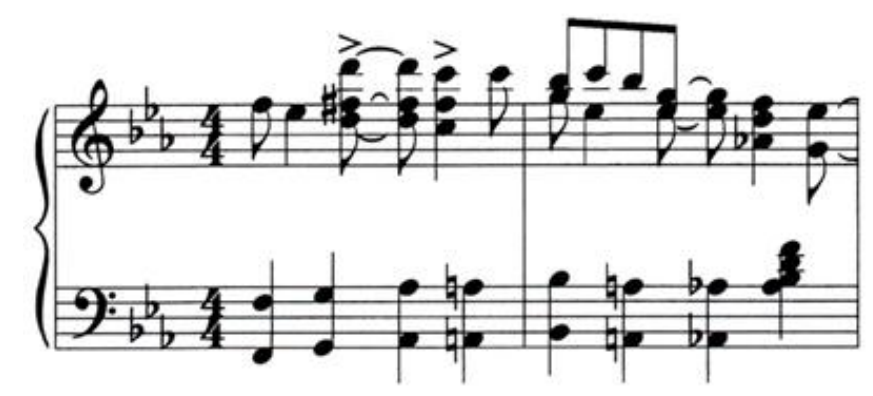

Example 4.12. The Mule Walk Walking Bass Line (mm. 98-99).

The harmonic language of The Mule Walk is exhibits the stride style in several ways.

First, the harmonic rhythm is fast with chords changing nearly every two beats. Second, there are many instances where extended harmony, particularly added ninths, is used [Ex. 4.13].

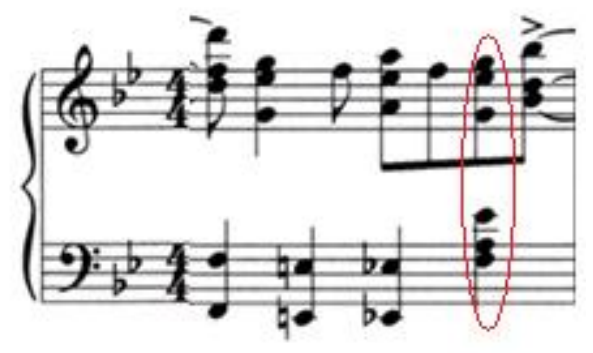

Example 4.13 The Mule Walk Added Ninth ( $\mathrm{F}_{7}$ with $\left.\mathrm{G}\right)(\mathrm{m} .19)$. 
Finally, Johnson occasionally incorporates blues notes [Ex. 4.14].

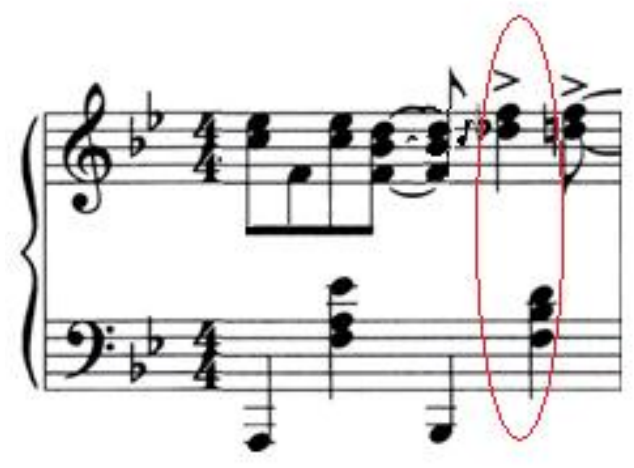

Example 4.14. The Mule Walk Lowered Third in B-flat Chord (m. 6).

The Mule Walk is one of the best examples of a composition in the stride style. Nearly every musical element in this work is representative of the idiom. First, the structure of Johnson's 1939 performance conforms exactly to "Typical Strain Arrangement No.1." Second, the melodies are based on riffs. Third, Johnson uses many of the left hand accompaniment patterns found in stride, including the "omm-pah" expansions and walking bass. Fourth, Johnson performs the work at a quick tempo, quarter note $=216$. Finally, the harmonic language in The Mule Walk, including the use of fast harmonic rhythm, extended harmony, and blues notes, is characteristic of the stride style.

While The Mule Walk is a standard in the stride repertory, the next piece analyzed, Willie “the Lion” Smith's Cuttin' Out, is less well-known. During Smith's trip to Paris in December 1949 he made the first of several "memoirs" albums, which include him playing, singing, and reminiscing. ${ }^{14}$ The 1949 memoir album contains Smith's only recording of Cuttin' Out. Furthermore, the 1949 memoir album is the only record of the work, as Smith never published Cuttin' Out. ${ }^{15}$

\footnotetext{
${ }^{14}$ Jasen and Jones, 97.

${ }^{15}$ Jasen and Tichenor, 250.
} 
The structure of Smith's 1949 recording of Cuttin' Out is Intro, $\mathrm{A}^{1}, \mathrm{~A}^{2}, \mathrm{~B}^{1}, \mathrm{~A}^{3}, \mathrm{C}^{1}, \mathrm{~A}^{4}$, $D^{1}, D^{2}, A^{5}, E^{1}, A^{6}$. Each strain is sixteen bars except $A^{6}$, which is extended by three measures. The presentation of strains in this performance is atypical compared to most stride compositions and recordings for several reasons. First, Smith repeats the "A" strain an unusually large number of times. Second, it is uncharacteristic to repeat the "A" strains after the trio sections. ${ }^{16}$ Finally, the harmonic scheme of the strains is unusual. All of the strains are in F major expect the "E" strain which is in the subdominant (B-flat Major). Typically all the trio strains ("C," "D," and "E") are in the subdominant (Table 4.3).

\begin{tabular}{|c|c|c|c|c|c|c|c|c|c|c|c|c|}
\hline \multicolumn{13}{|c|}{ FORM } \\
\hline Section: & Intro: & $A^{1}$ & $\mathrm{~A}^{2}$ & $\mathrm{~B}^{1}$ & $A^{3}$ & $\mathrm{C}^{1}$ & $\mathrm{~A}^{4}$ & $\mathrm{D}^{1}$ & $\mathrm{D}^{2}$ & $A^{5}$ & $E^{1}$ & $A^{6}$ \\
\hline $\begin{array}{c}\text { Measure } \\
\text { Numbers: } \\
\end{array}$ & $1-4$ & $\begin{array}{l}5- \\
20 \\
\end{array}$ & $\begin{array}{r}21- \\
36 \\
\end{array}$ & $\begin{array}{c}37- \\
52 \\
\end{array}$ & $\begin{array}{c}53- \\
68 \\
\end{array}$ & $\begin{array}{c}69- \\
84 \\
\end{array}$ & $\begin{array}{l}85- \\
100 \\
\end{array}$ & $\begin{array}{c}101- \\
116\end{array}$ & $\begin{array}{r}117- \\
132\end{array}$ & $\begin{array}{r}133- \\
148 \\
\end{array}$ & $\begin{array}{c}149- \\
164\end{array}$ & $\begin{array}{r}165- \\
185 \\
\end{array}$ \\
\hline Key: & $\mathrm{F}$ & $\mathrm{F}$ & $\mathrm{F}$ & $\mathrm{F}$ & $\mathrm{F}$ & $\mathrm{F}$ & $\mathrm{F}$ & $\mathrm{F}$ & $\mathrm{F}$ & $\mathrm{F}$ & $\begin{array}{l}\text { B- } \\
\text { flat }\end{array}$ & $\mathrm{F}$ \\
\hline
\end{tabular}

Table 4.3 Thematic Presentation in Willie “the Lion” Smith's 1949 Recording of Cuttin' Out.

The melody in Cuttin' Out is based on riffs and grooves. During the "A" strains Smith plays three different four-bar riffs labeled ('a', 'b', and 'c') that are arranged $\left(a^{1} b a^{2} c\right)$. The melody and rhythm in ' $\mathrm{a}$ ", is the same in each " $\mathrm{A}$ " strain [Ex. 4.15].

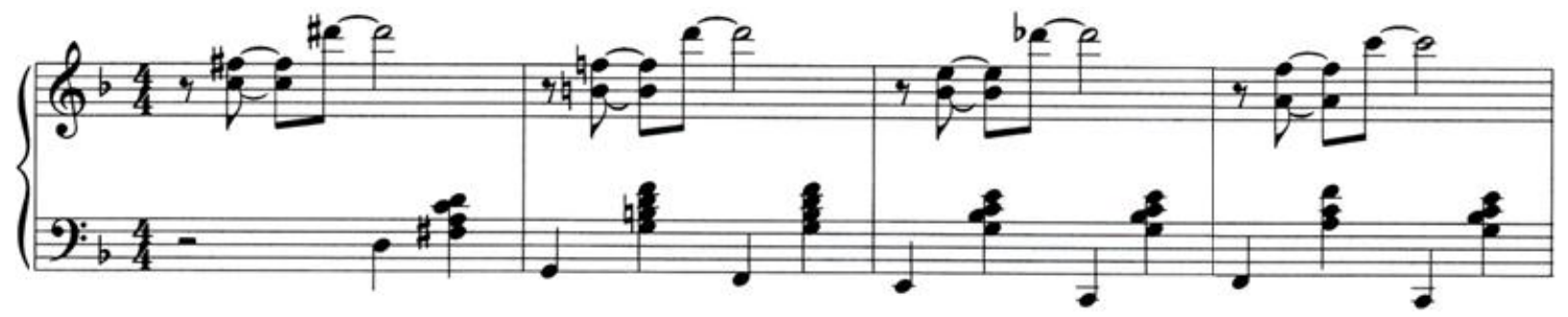

Example 4.15. Cuttin' Out "A" 'a1' Riff (mm. 5-8).

${ }^{16}$ A trio refers to the strains that occur after the "B" strain. Additionally, trios usually are in a different key from the opening strains. When a stride composition is in a major mode, the trio sections are usually in the key of the subdominant. When a stride composition is in a minor mode, the trio sections usually are in the key of the subdominant of the relative major. See page 56 for further explanation. 
Smith modifies the rhythm and melody of ' $\mathrm{a}$ " to create ' $\mathrm{a}$ "., Every restatement of the "A" strain contains a different version of ' $\mathrm{a}^{2}$ ' [Ex. 4.16].

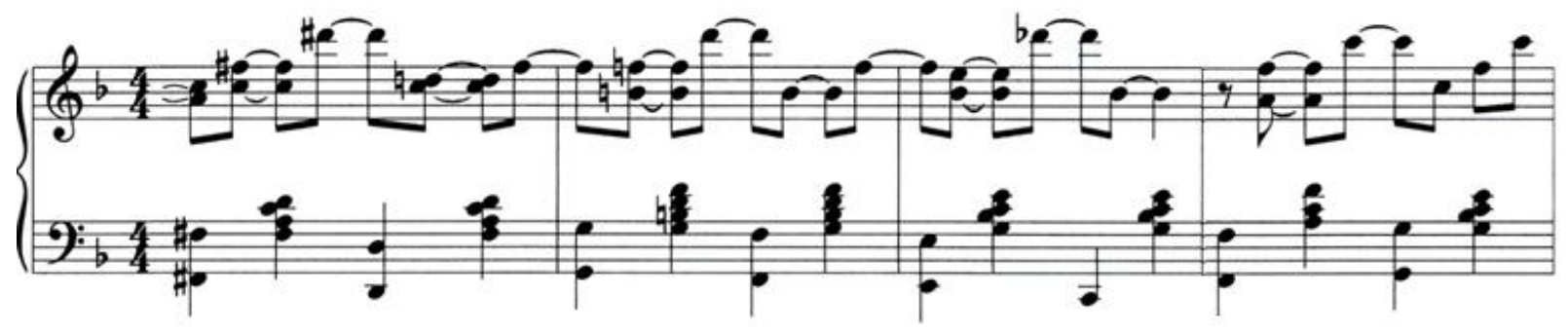

Example 4.16. Cuttin' Out "A" 'a2, Riff, Rhythmic Variation (mm. 61-64).

The ' $b$ ' and 'c' riffs contain different harmonies, melodic material, and rhythms from ' $a$ '.

Furthermore, in each recurrence of "A," Smith alters the melody and rhythm of ' $\mathrm{b}$ ' and 'c' [Ex. 4.17] [Ex. 4.18].

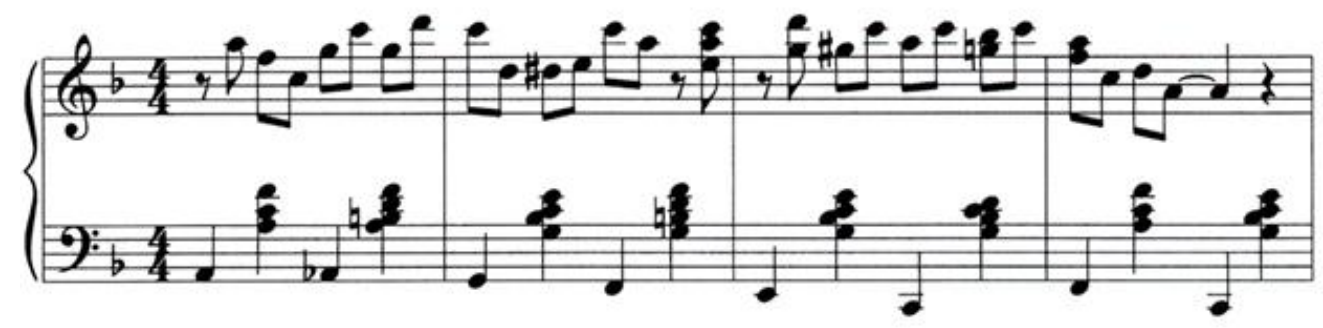

Example 4.17a. Cuttin' Out “A” 'b’ Riff (mm. 9-12).

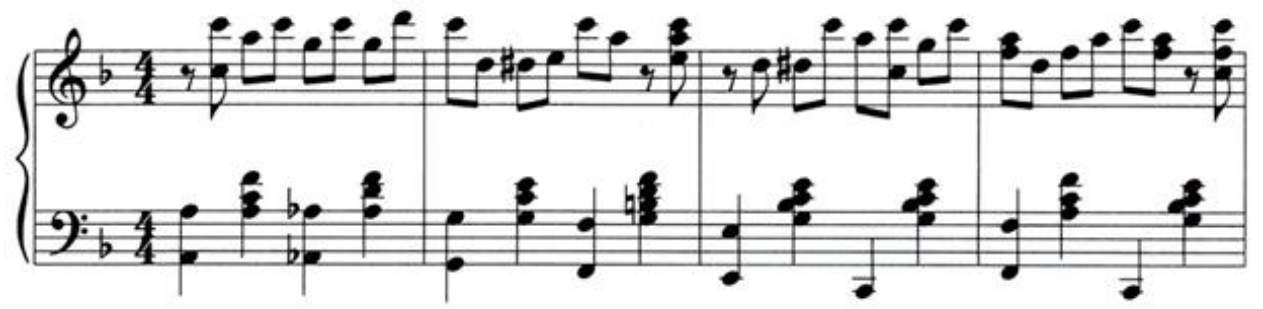

Example 4.17b. Cuttin' Out “A” 'b’ Riff, Melody Altered (mm. 25-28). 


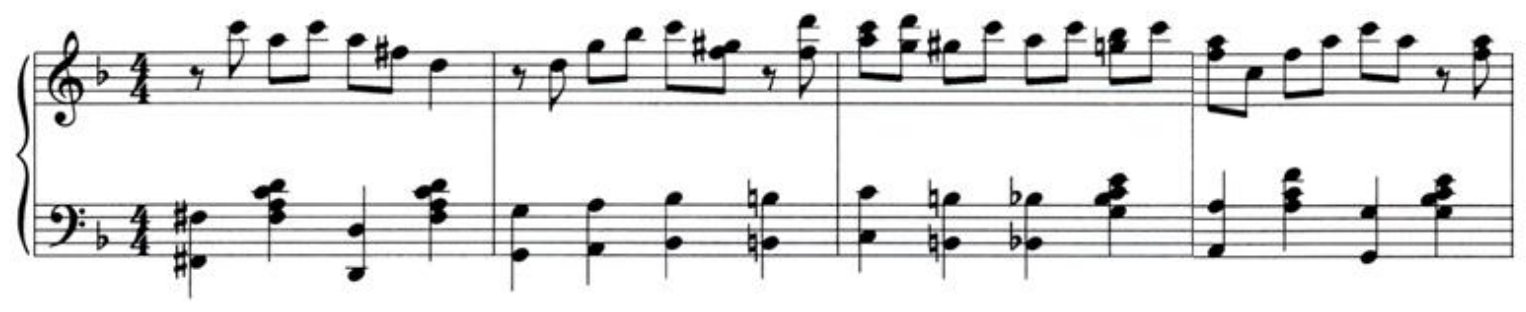

Example 4.18a. Cuttin' Out “A” 'c' Riff (mm. 17-20).

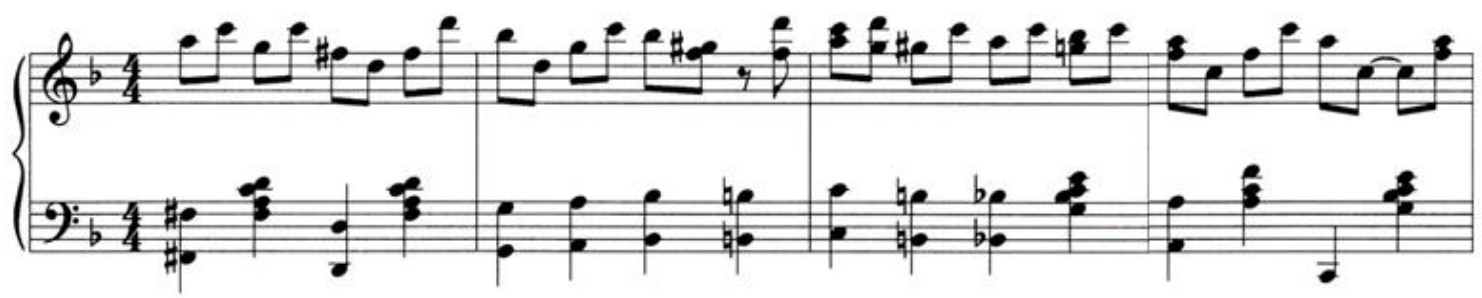

Example 4.18b. Cuttin' Out “A” 'c' Riff, Melody Altered (mm. 33-36).

The melody in " $\mathrm{B}$ ", is based on a four-bar groove that is repeated four times [Ex. 4.19].
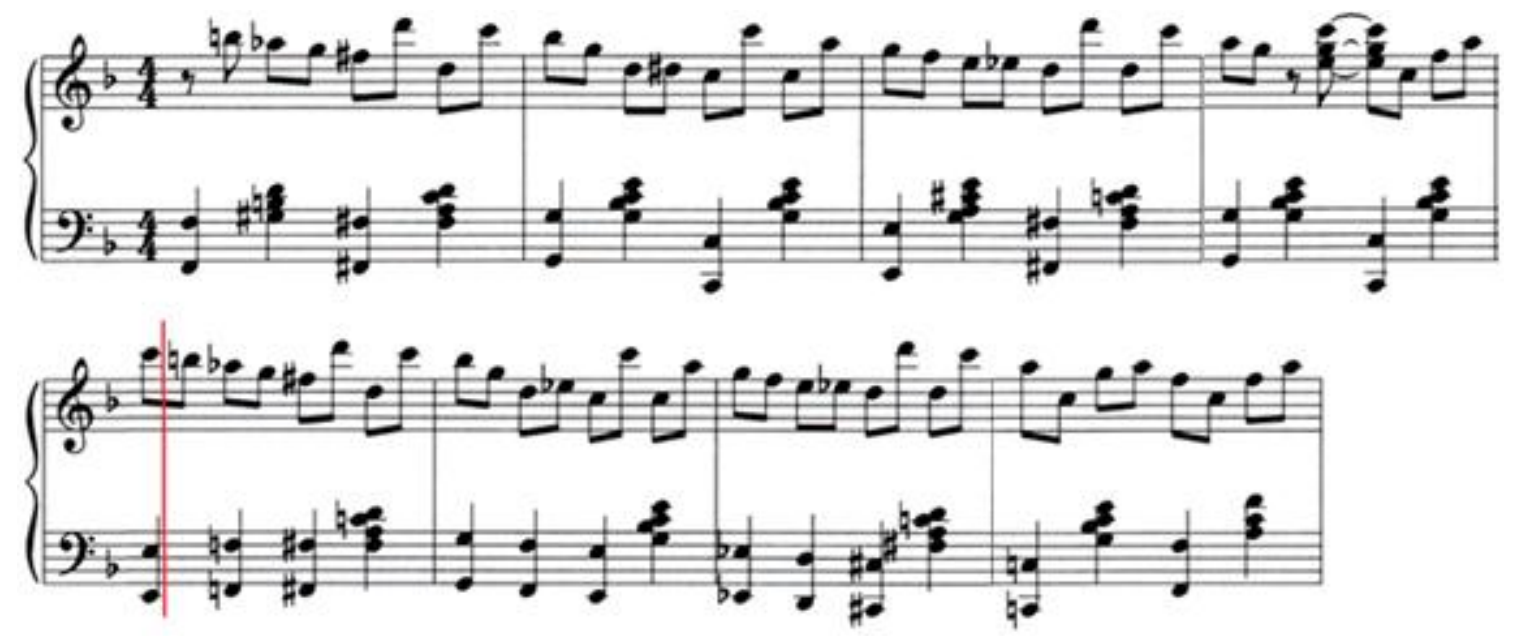

Example 4.19. Cuttin' Out 'B" ${ }^{1 /}$ Groove (mm. 37-44). 
In "C ${ }^{1 \text { " }}$ Smith plays a four-bar riff that he repeats and alters melodically and rhythmically three times [Ex. 4.20]. During the last four measures of " $\mathrm{C}$ " "Smith plays the " $\mathrm{c}$ ' riff from the "A" strain.

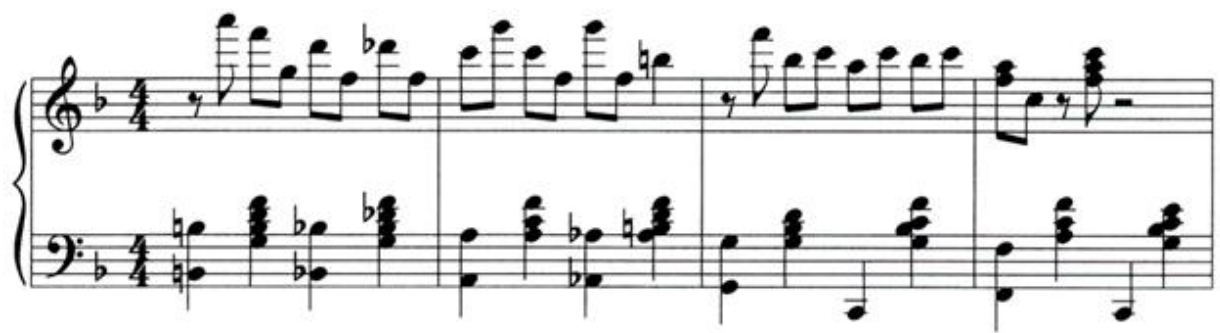

Example 4.20a. Cuttin' Out “C ${ }^{1}$ ” Riff (mm. 69-72).

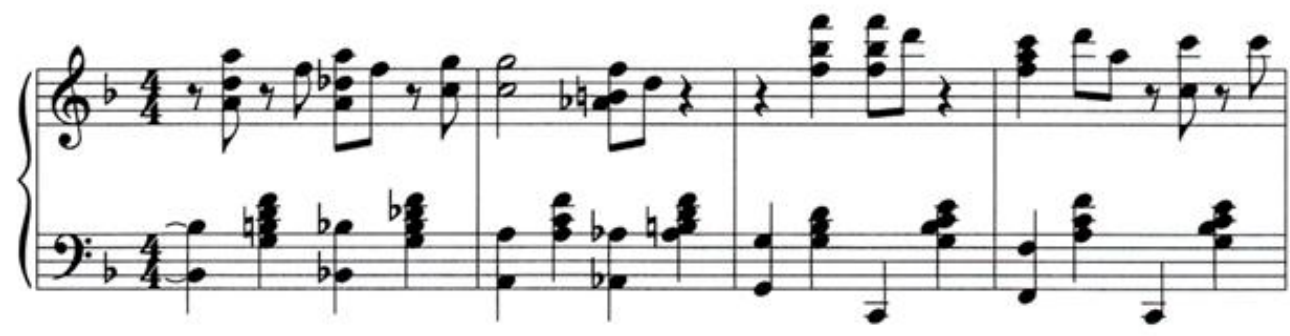

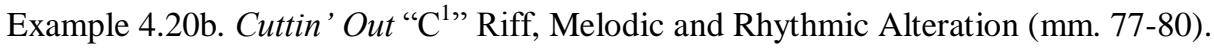

" $\mathrm{D}$ " " and " $\mathrm{D}$ "' are based on a four-bar riff that is repeated and varied four times [Ex. 4.21]. ${ }^{17}$

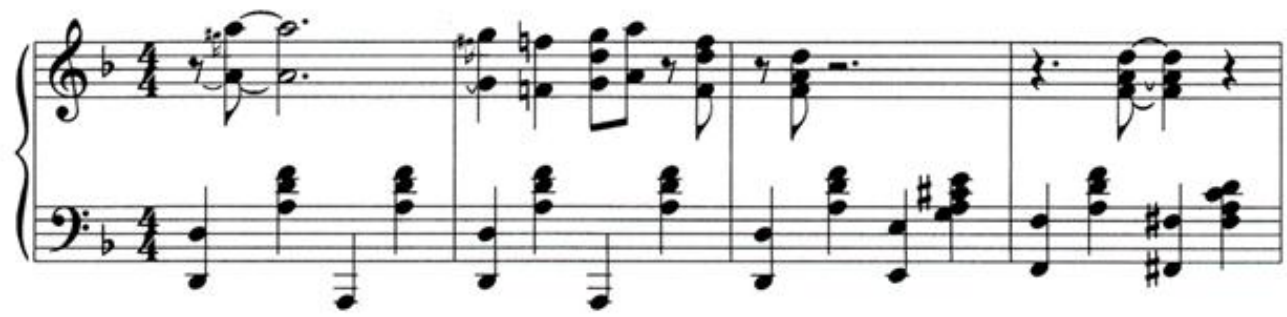

Example 4.21a. Cuttin' Out 'D”' Riff (mm. 101-104).

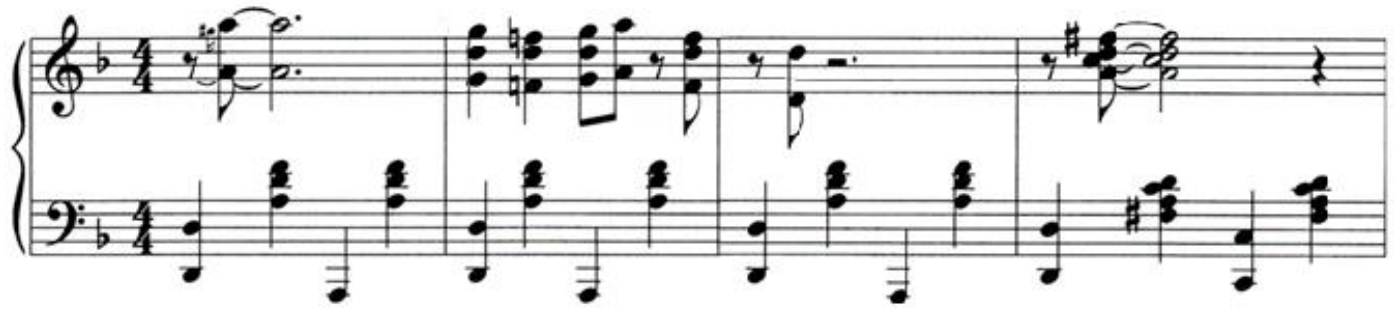

${ }^{17}$ Since the rhythm and pitches of the "D" strain thematic block are different each time, it is best to label this melodic figure as a riff rather than a groove. 
Finally, the melody in " $\mathrm{E}$ "' is constructed using two separate four-bar riffs labeled ' $\mathrm{a}$ ' and ' $\mathrm{b}$ ' that alternate (abab) [Ex. 4.22].
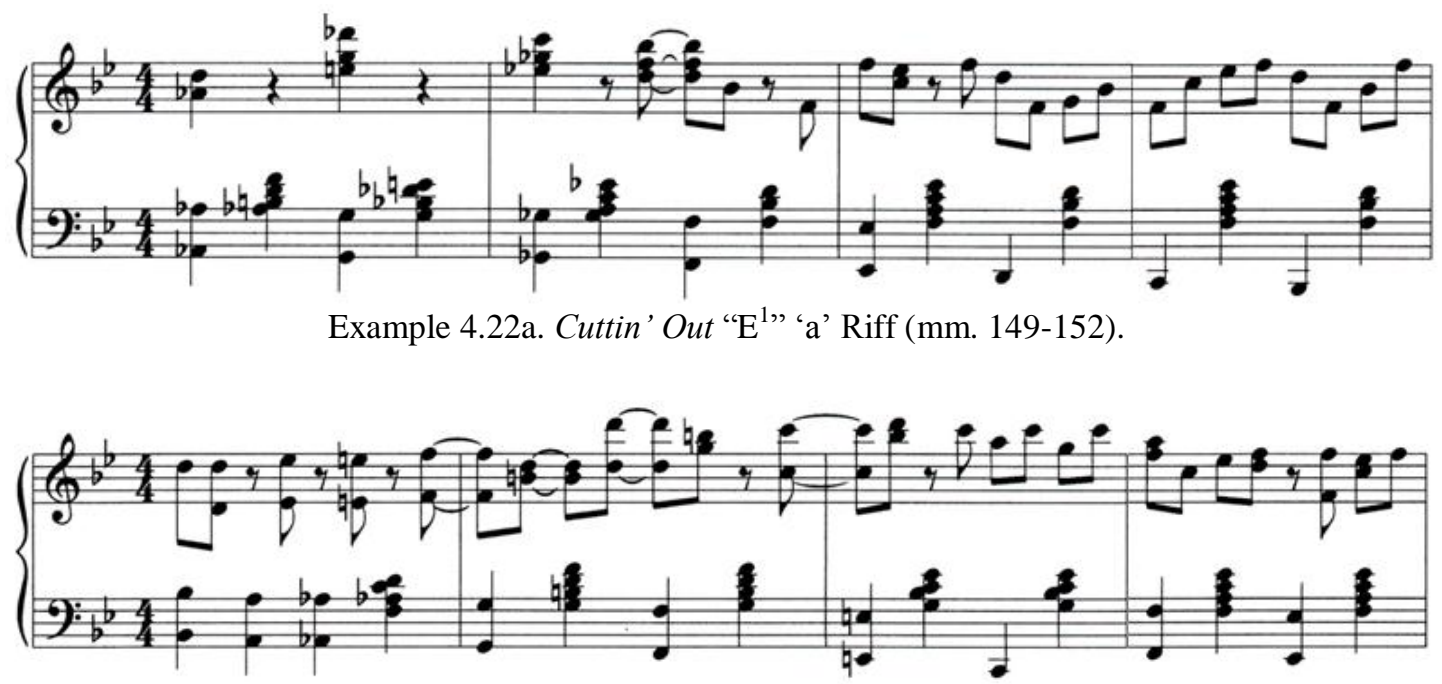

Example 4.22b. Cuttin' Out “E" '”, 'b' Riff (mm. 153-156).

The left hand accompanimental patterns in this recording are rooted in the ragtime style rather than stride. The primary accompanimental device Smith used is the "omm-pah." Smith's "stride" in this recording is compact and has very few wide leaps [Ex. 4.23]. Perhaps the lack of large strides is due to his choice of tempo, with a quarter-note equaling 250 .

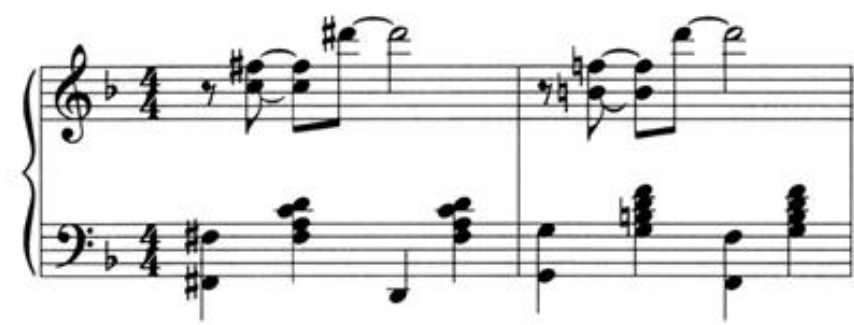

Example 4.23. Cuttin' Out Compact “Omm-pah” (mm. 21-22). 
Smith occasionally incorporates stride left hand devices in this recording, notably walking-bass passages [Ex. 4.24]. Most of these passages are short, only one measure. However, at the end of a strain he plays longer walking bass lines, occasionally up to two bars in length.

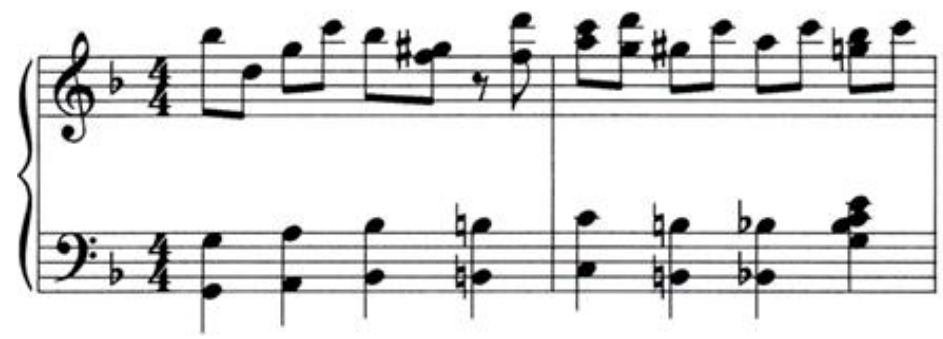

Example 4.24. Cuttin’ Out Walking Bass Line (mm. 34-35).

Additionally, near the end of the piece Smith plays a tango rhythm in the left hand [Ex. 4.25].

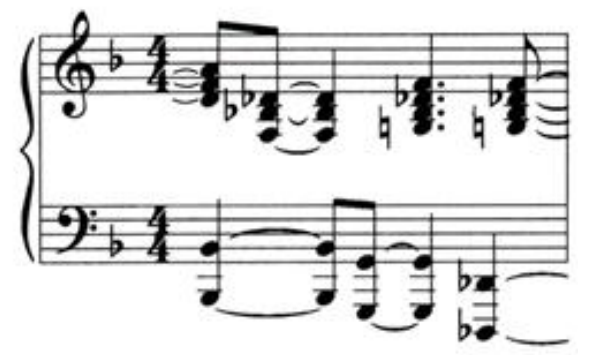

Example 4.25. Cuttin' Out Tango Rhythm (left hand) (m. 183).

There are elements of the ring shout and other dance music influences in Cuttin' Out.

First, as discussed earlier, the melodies are largely based on riffs and grooves. Second, Smith frequently uses off-beat melodic lines, particularly in the "A" strains [Ex. 4.26]. Finally, there are many instances of complex syncopation with the most elaborate syncopation occurring at the end of the piece [Ex. 4.27]. 

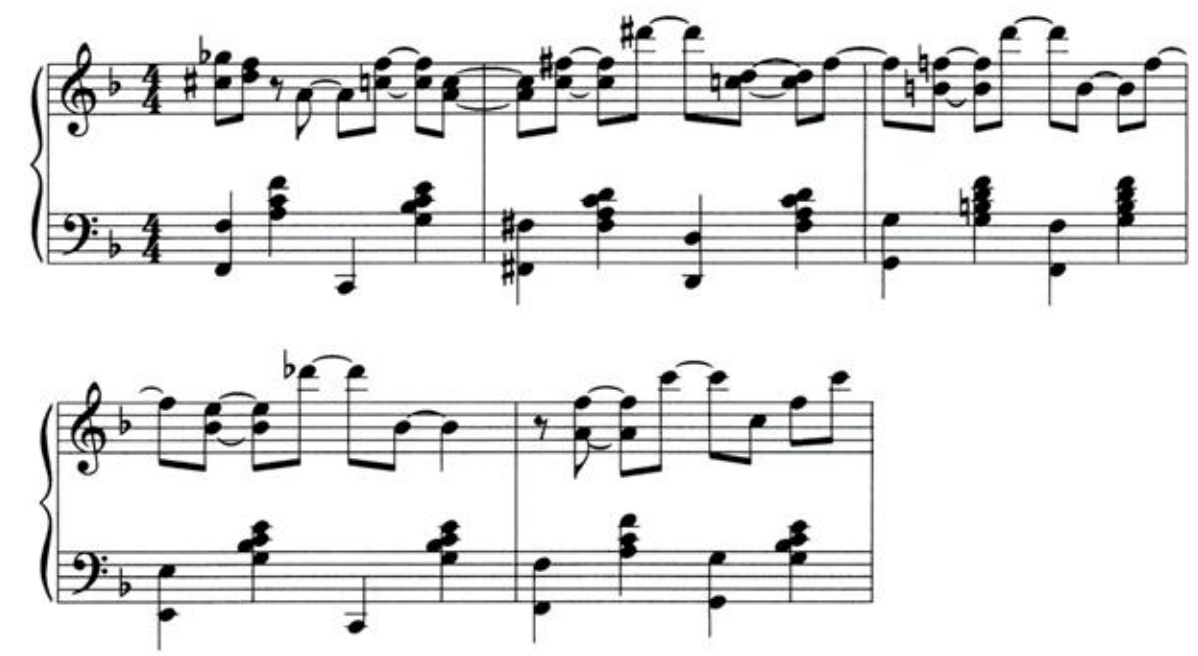

Example 4.26. Cuttin' Out Off-Beat Melody (mm. 60-64).

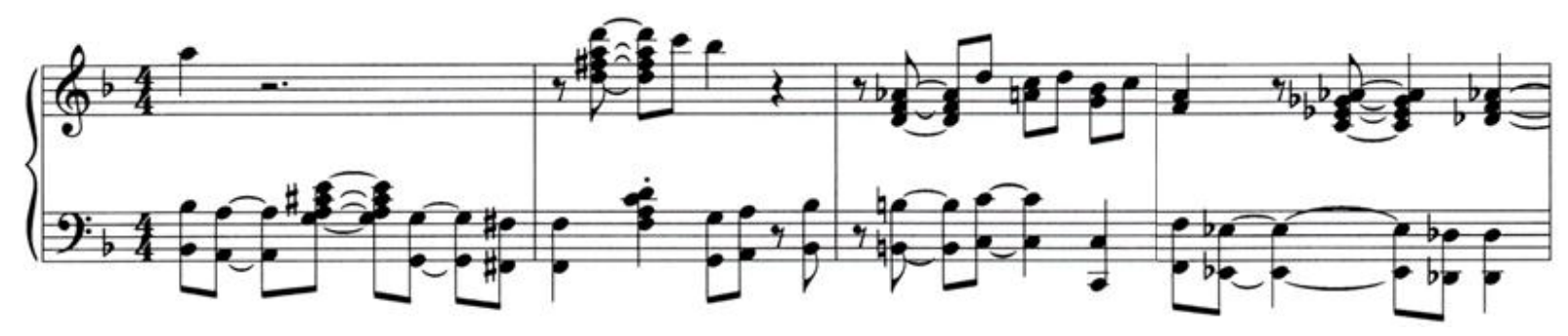

Example 4.27. Cuttin' Out Complex Syncopation (mm. 179-182).

In general, Cuttin' Out features many of the musical traits found in the stride style. The melodies are based on riffs and grooves and there are a few passages that make use of ring shout musical devices. The left hand accompaniments resemble both the ragtime style (in the predominance of the "omm-pah,") and the stride style (in the use of walking bass and tango rhythms). However, the structure of Cuttin' Out is atypical for a stride composition. First, the "A" strain is repeated an unusually large number of times. Second, all of the strains are in the same key except the "E" strain. Typically the trio strains ("C", "D", and "E") are in the subdominant. Finally, it is unusual that Smith plays the "A" strains after the trio sections.

Two decades prior to Smith's recording of Cuttin' Out, Fats Waller wrote one of the most well-known stride compositions, Handful of Keys (1929). Published by Southern Music 
Publishing Company, Handful of Keys is a virtuosic show piece equivalent to that of James P.

Johnson's Carolina Shout. Around a decade later Benny Goodman's Band made a popular arrangement of Handful of Keys. ${ }^{18}$

The structure of Handful of Keys is unusual compared to the three previously discussed pieces which all had formal characteristics associated with ragtime's, such as sixteen bar strains and multi-strain formats. Waller uses thirty-two-bar form, one of the most popular song forms of the mid-1920s, as the structural basis of this piece. ${ }^{19}$ Most thirty-two-bar songs have four eightbar phrases that are arranged (aaba). The 'b' phrase contrasts with the 'a' phrase melodically and harmonically. ${ }^{20}$

In Handful of Keys Waller wrote two different thirty-two-bar choruses ${ }^{21}$ labeled "A" and "B" arranging them (Intro, $\mathrm{A}^{1}, \mathrm{~A}^{2}$, Interlude, $\mathrm{B}^{1}, \mathrm{~A}^{3}, \mathrm{~A}^{4}$ ) (Table 4.4).

\begin{tabular}{|c|c|c|c|c|c|c|c|}
\hline \multicolumn{8}{|c|}{ FORM } \\
\hline Section: & Intro & $\mathrm{A}^{1}$ & $\mathrm{~A}^{2}$ & Interlude & $\mathrm{B}^{1}$ & $\mathrm{~A}^{3}$ & $\mathrm{~A}^{4}$ \\
\hline $\begin{array}{l}\text { Measure } \\
\text { Numbers: }\end{array}$ & $1-8$ & $9-40$ & $41-72$ & $73-76$ & $77-108$ & $109-140$ & $141-175$ \\
\hline Key: & $\mathrm{F}$ & $\mathrm{F}$ & $\mathrm{F}$ & $\mathrm{F}$ & B-flat & $\mathrm{F}$ & $\mathrm{F}$ \\
\hline
\end{tabular}

Table 4.4. Thematic Presentation in Fats Waller's 1929 Recording of Handful of Keys.

\footnotetext{
${ }^{18}$ Paul Posnak, Thomas "Fats” Waller: The Great Solos 1929-1937. (Milwaukee: Hal Leonard, 1999), 6.

${ }^{19}$ Alec Wilder, American Popular Song: the Great Innovators 1900-1950, (New York: Oxford University Press, 1972), 56.

${ }^{20}$ Thomas Owens, "Forms." The New Grove Dictionary of Jazz, 2nd ed. In Grove Music Online. Oxford Music Online. Oxford University Press (accessed November 13, 2012), <http://www.oxfordmusiconline.com/subscriber/article/grove/music/J154400> ed., s.v. "chorus."
} 
Each "A" chorus contains four eight-bar phrases arranged (aaba). The harmony of the 'a' phrases consists of tonic and dominant chords arranged (I-I-V-V-V-V-I-V). In 'b' the harmony is based on dominant-seventh chords organized in a circle progression ( $\left.\mathrm{III}_{7}-\mathrm{III}_{7}-\mathrm{VI}_{7}-\mathrm{VI}_{7}-\mathrm{II}_{7}-\mathrm{II}_{7}-\mathrm{V}_{7}-\mathrm{V}_{7}\right)$ (Table 4.5).

\begin{tabular}{|c|c|c|c|c|c|c|c|c|}
\hline \multicolumn{9}{|c|}{ "A" CHORUS FORMAT } \\
\hline $\begin{array}{l}\text { Measure } \\
\text { Number: }\end{array}$ & 1 & 2 & 3 & 4 & 5 & 6 & 7 & 8 \\
\hline Chord: & $\overline{\mathrm{I}}$ & $\mathrm{I}$ & $\mathrm{V}$ & $\mathrm{V}$ & $\mathrm{V}$ & $\mathrm{V}$ & $\underline{\mathrm{I}}$ & $\mathrm{V}$ \\
\hline Riff: & \multicolumn{2}{|c|}{$\mathrm{X}$} & \multicolumn{2}{|c|}{$\mathrm{X}$} & \multicolumn{2}{|c|}{$\mathrm{X}$} & \multicolumn{2}{|c|}{ (break) } \\
\hline \multicolumn{9}{|c|}{ 'a' } \\
\hline $\begin{array}{l}\text { Measure } \\
\text { Number: }\end{array}$ & 9 & 10 & 11 & 12 & 13 & 14 & 15 & 16 \\
\hline Chord: & $\overline{\mathrm{I}}$ & $\mathrm{I}$ & $\mathrm{V}$ & $\mathrm{V}$ & $\mathrm{V}$ & $\mathrm{V}$ & $\underline{\mathrm{I}}$ & $\overline{\mathrm{V}}$ \\
\hline Riff: & \multicolumn{2}{|c|}{$\bar{X}$} & \multicolumn{2}{|c|}{$\bar{X}$} & \multicolumn{2}{|c|}{$\mathrm{X}$} & \multicolumn{2}{|c|}{ (break) } \\
\hline \multicolumn{9}{|c|}{ 'b' } \\
\hline $\begin{array}{l}\text { Measure } \\
\text { Number: }\end{array}$ & 17 & 18 & 19 & 20 & 21 & 22 & 23 & 24 \\
\hline Chord: & $\overline{\mathrm{IIII}}$ & $\mathrm{III}_{7}$ & $\overline{\mathrm{VI}_{7}}$ & $\overline{\mathrm{VI}}$ & $\mathrm{II}_{7}$ & $\overline{\mathrm{II}_{7}}$ & $\overline{\mathrm{V}} \mathrm{V}_{7}$ & $\overline{V_{7}}$ \\
\hline Riff: & \multicolumn{2}{|c|}{$\overline{\mathrm{Y}}$} & \multicolumn{2}{|c|}{$\overline{\mathrm{Y}}$} & \multicolumn{2}{|c|}{$\mathrm{Y}$} & \multicolumn{2}{|c|}{ (break) } \\
\hline \multicolumn{9}{|c|}{ ' $a$ ' } \\
\hline $\begin{array}{l}\text { Measure } \\
\text { Number: }\end{array}$ & 25 & 26 & 27 & 28 & 29 & 30 & 31 & 32 \\
\hline Chord: & $\mathrm{I}$ & $\mathrm{I}$ & $\mathrm{V}$ & $\mathrm{V}$ & $\mathrm{V}$ & $\mathrm{V}$ & $\mathrm{I}$ & $\mathrm{V}$ \\
\hline Riff: & \multicolumn{2}{|c|}{ X } & \multicolumn{2}{|c|}{ X } & \multicolumn{2}{|c|}{$\bar{X}$} & \multicolumn{2}{|c|}{ (break) } \\
\hline
\end{tabular}

Table 4.5. Phrase Structure of Handful of Keys.

The melody of the "A" choruses is based on two separate riffs. The first riff $(\mathrm{X})$ corresponds with the 'a' phrases. $(\mathrm{X})$ is two-measures and is presented three times within each 'a' phrase. A two-measure break follows the third statement of (X). In Waller's recording he 
makes no significant alterations to $(\mathrm{X})$ within each " $\mathrm{A}$ " chorus. ${ }^{22}$ However, Waller varies $(\mathrm{X})$ in each subsequent "A" chorus. [Ex. 4.28].

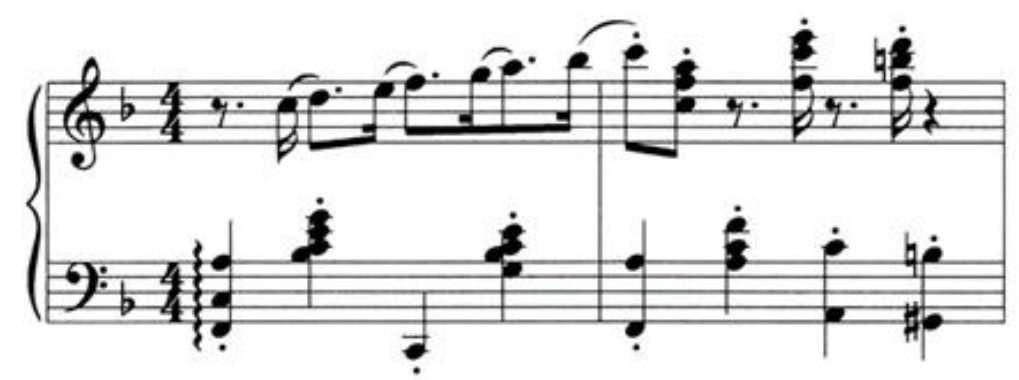

Example 4.28a. Handful of Keys "A" "(X) Riff (mm. 9-10).

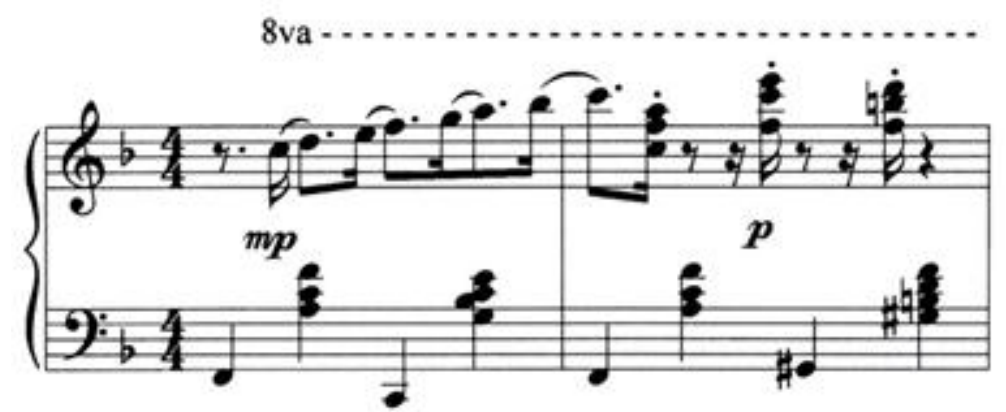

Example 4.28b. Handful of Keys “ $\mathrm{A}^{2 ”}$ (X) Riff, 8va Added and New Accompaniment (mm. 41-42).

The second riff $(Y)$ corresponds with ' $b$ '. The ' $b$ ' phrase is constructed the same as ' $a$ ' in that the (Y) riff is presented three times followed by a two-measure break. Additionally, Waller treats $(\mathrm{Y})$ the same as the $(\mathrm{X})$ in that he makes no significant alterations to $(\mathrm{Y})$ within each "A" chorus. However, Waller varies (Y) in each subsequent "A" chorus [Ex. 4.29].

${ }^{22}$ It is best to classify the melodic material in the "A" strains as a riff rather than a groove since the underlying accompaniment and chord voicings associated with each subsequent thematic block are varied. 


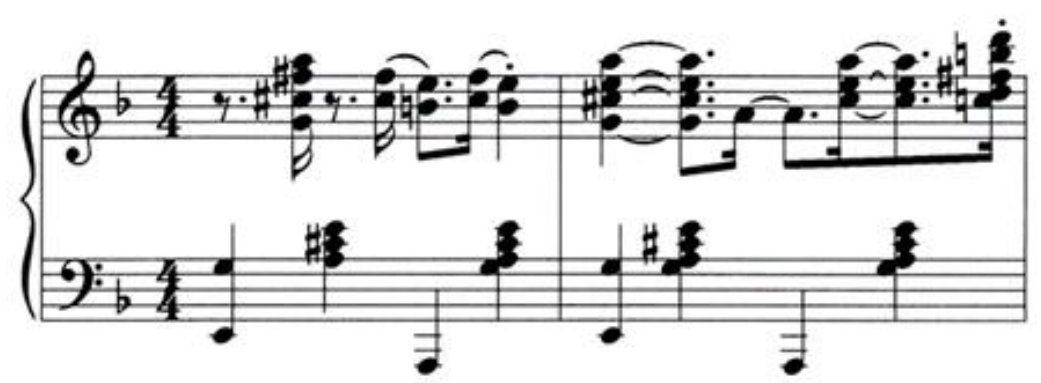

Example 4.29a. Handful of Keys “A”"(Y) Riff (mm. 25-26).

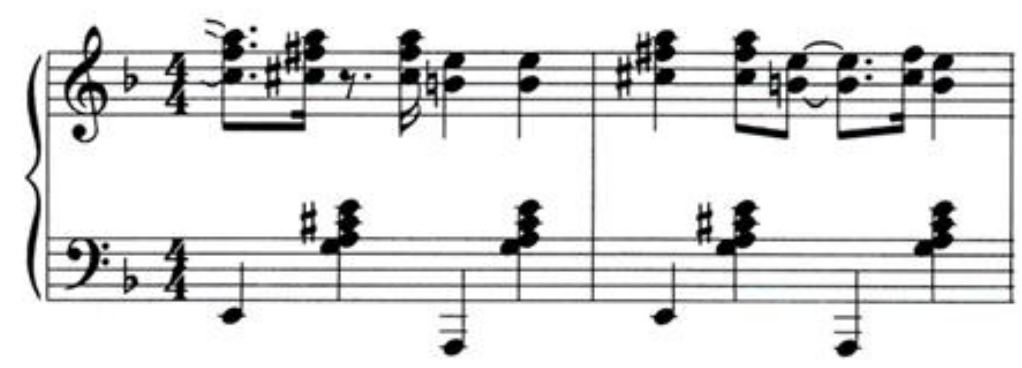

Example 4.29b. Handful of Keys “A" ${ }^{4,}$ (Y) Riff, New Rhythm (mm. 157-158).

After " $\mathrm{A}$ " "Waller plays a four-bar interlude that functions as a harmonic transition between the key of " $\mathrm{A}^{2}$," F major, and the key of " $\mathrm{B}$," $\mathrm{B}$-flat major. The final chord of the interlude $\left(\mathrm{F}^{7}\right)$ functions as the pivot chord [Ex. 4.30].

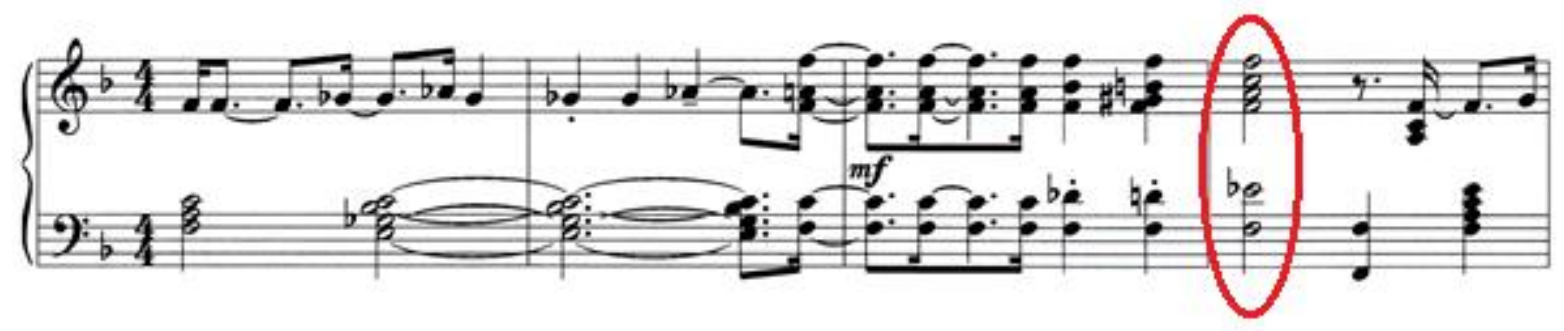

Example. 4.30. Handful of Keys Interlude (mm. 73-76).

The melodic construction of " $\mathrm{B}$ " is significantly different than the " $\mathrm{A}$ " chorus in that there is no discernible riff or groove. Instead, Waller performs a series of eight four-bar "tricks" 
in " $\mathrm{B}$." According to Posnak, there are multiple instances where Waller substituted the standard riff and variation formula in favor of playing chordal passages [Ex. 4.31], cascading triplets, double note passages, alternating octaves [Ex. 4.32] and other "tricks" during middle and late strains and choruses. ${ }^{23}$
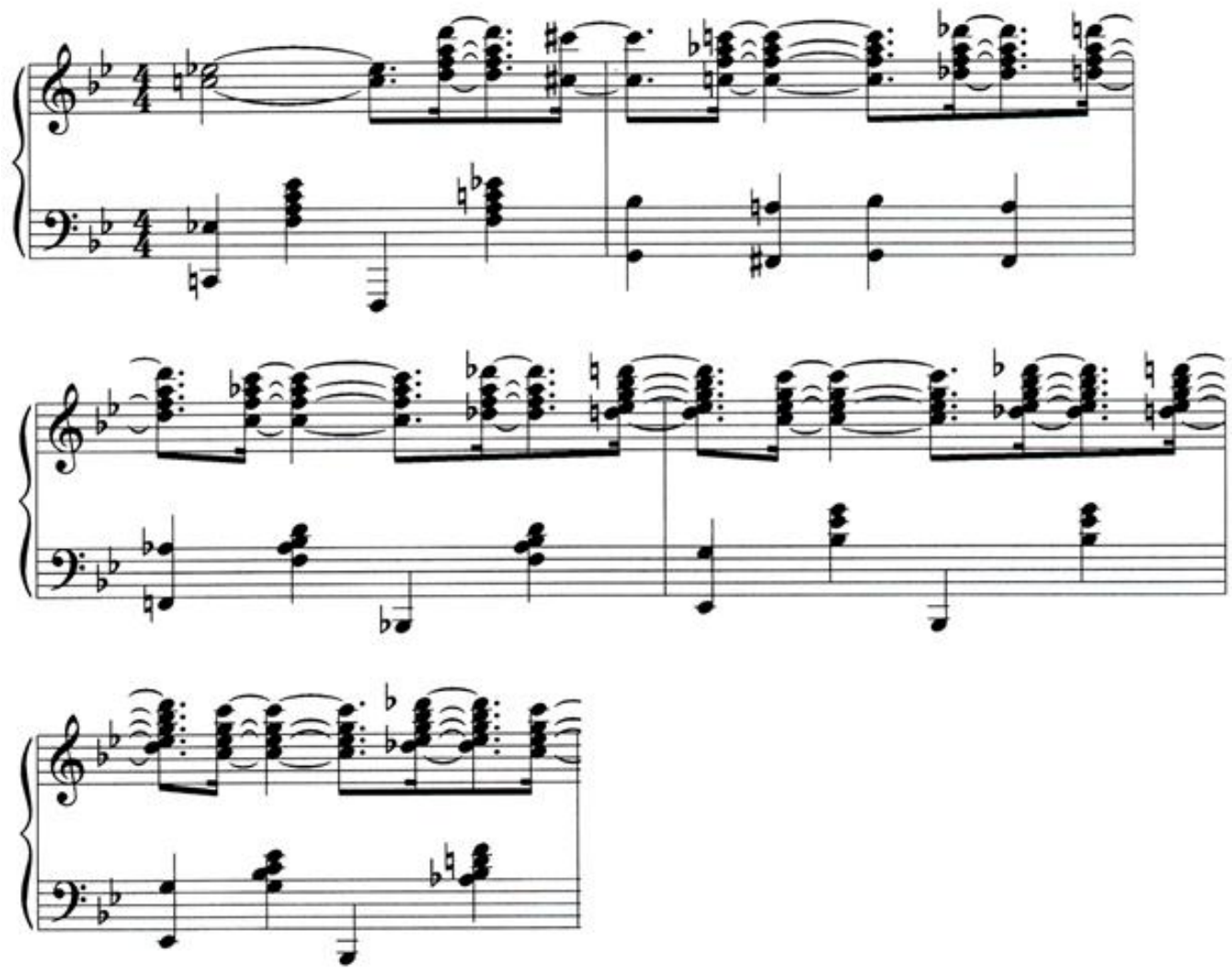

Example 4.31. Handful of Keys Trick (chordal passage) in "B" ${ }^{1 /}$ (mm. 96-100).

\footnotetext{
${ }^{23}$ Posnak, 6.
} 

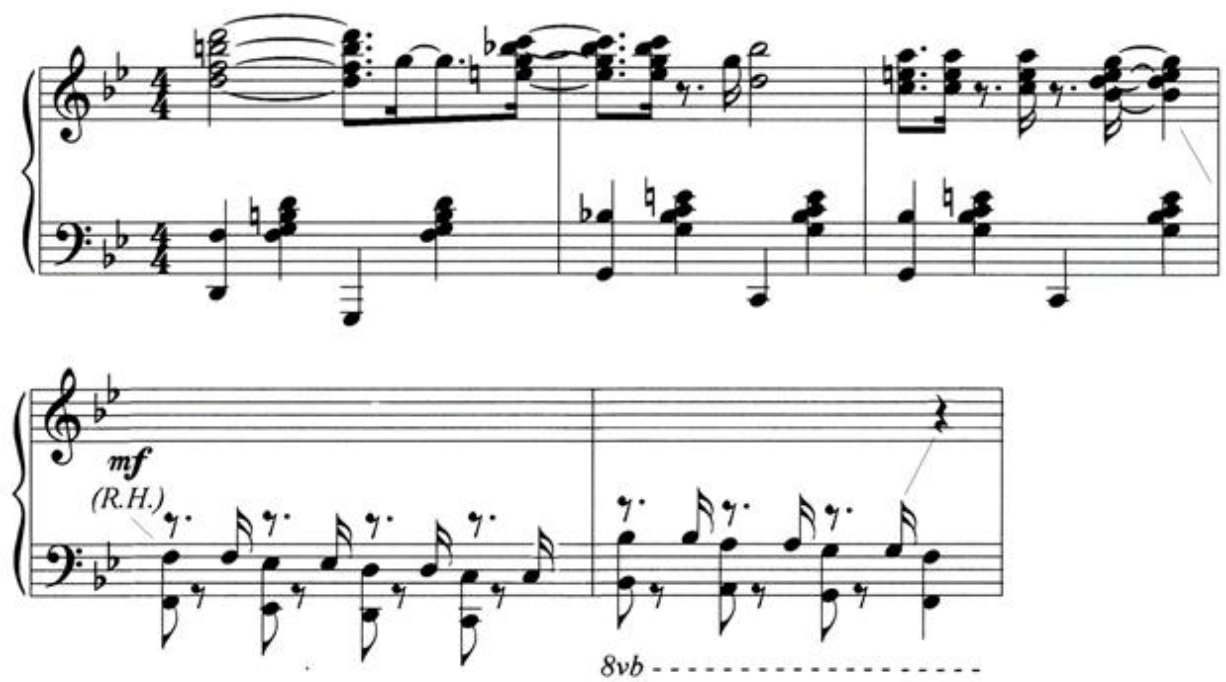

Example 4.32. Handful of Keys Trick (alternating octaves) in "B" (mm. 88-92).

The harmonic language of " $\mathrm{B}$ "" is representative of the stride style in several ways. First, the harmonic rhythm is fast. Nearly every two-beats Waller plays a new chord [Ex. 4.33].

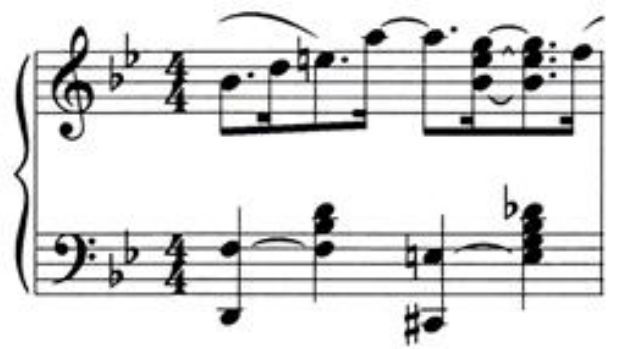

Example 4.33. Handful of Keys Fast Harmonic Rhythm (m. 94).

Second there is an abundance of extended harmony throughout " $\mathrm{B}$ ", [Ex. 4.34].

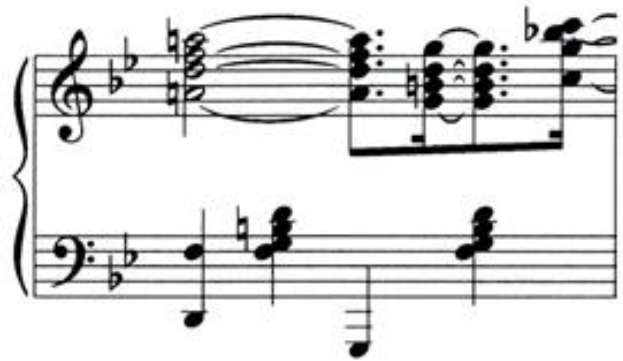

Example 4.34. Handful of Keys Extended Harmony (added ninth on the $\mathrm{G}^{7}$ chord) (m. 104). 
Waller used a variety of left hand accompanimental devices in this recording. Like the previously discussed pieces, the primary left hand accompaniment Waller used was the "ommpah." In this recording he frequently played wide "strides" and executed them at extraordinarily fast tempo (half note $=126)$ ! In one instance, his stride spans two octaves [Ex. 4.35].

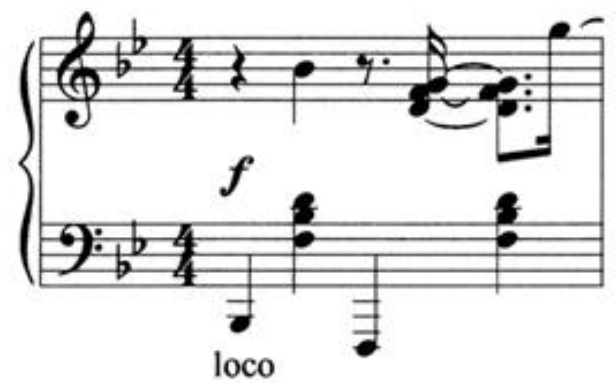

Example 4.35. Handful of Keys Wide Stride (m. 93).

In a few spots Waller played walking bass lines [Ex. 4.36].

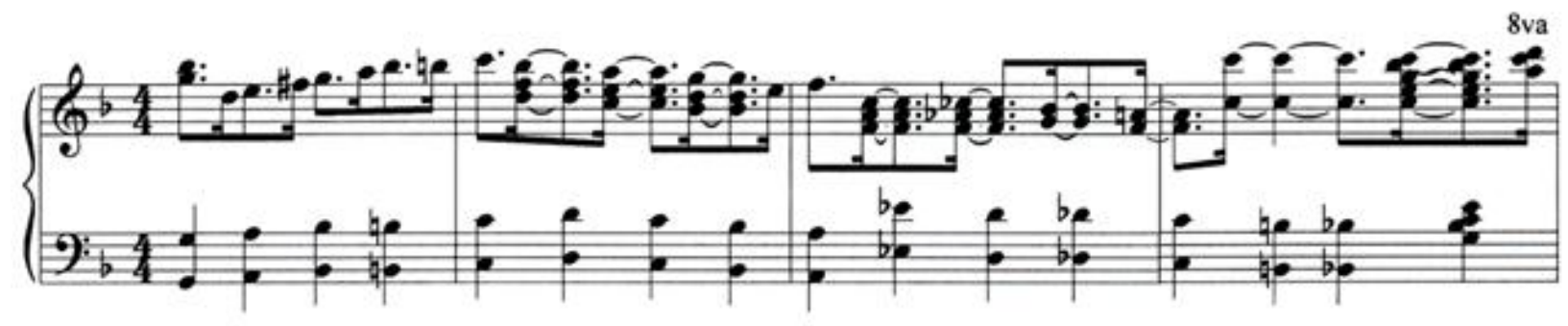

Example 4.36 Handful of Keys Walking Bass Line (mm. 137-140).

Finally, there are many instances when Waller played tenths in lieu of octaves in left hand passages [Ex. 4.37].

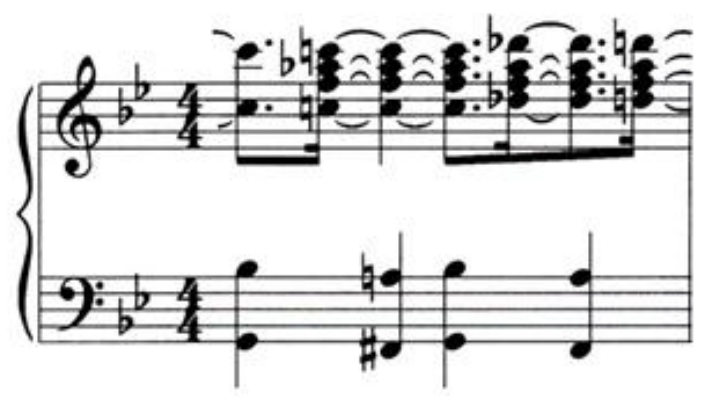

Example 4.37 Handful of Keys Tenths (m. 97). 
There are elements of the ring shout in Handful of Keys, in particular, call-and-response during the "A" chorus riffs [Ex. 4.38]. Waller achieved this through changes of texture. During the "call" the right hand consists of a rising single-note line. For the "response" the right hand switches to off-beat chords.

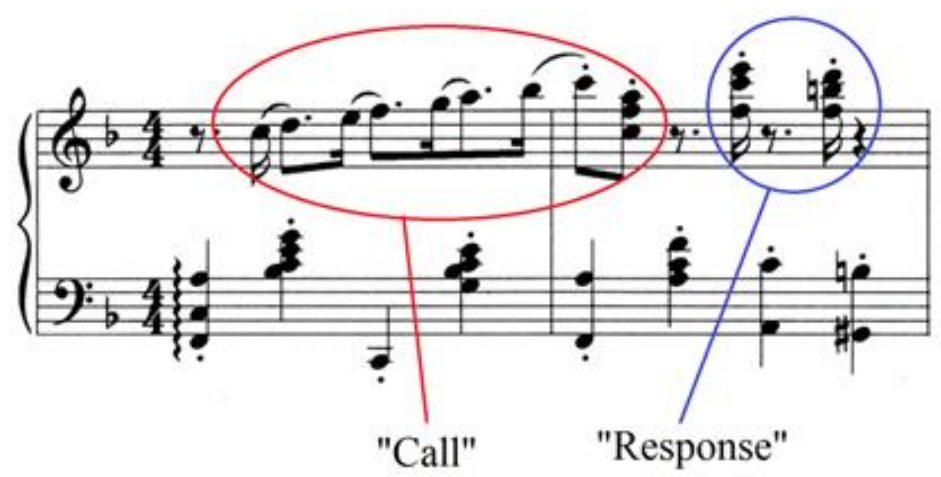

Example 4.38 Handful of Keys Call-and-Response (mm. 9-10).

Waller's interest in popular music and showmanship is apparent in Handful of Keys. Instead of using the rigid sixteen-bar strain formula associated with ragtime, Waller integrates one of the most popular song forms of the mid-1920s, the thirty-two-bar form, into this composition. To make this piece flashy Waller incorporates an array of "tricks," such as alternating octaves, and difficult left hand accompaniments, such as wide strides and frequent use of tenths on the strong beats of his "omm-pah."

Waller's gift as a composer is apparent in Handful of Keys. The majority of this piece is constructed on two short melodic riffs. However, in each new section of the composition Waller varies these two riffs in creative ways by using new textures, accompaniments, rhythms, and melodic alterations.

These four recordings demonstrate why Roberts, Johnson, Smith, and Waller sat atop the stride hierarchy. Each recording is filled with virtuosic playing and imaginative thematic 
ideas. Additionally, these recordings are filled with call-and-response devices and rhythmic grooves - the type of music that audiences at venues such as "The Jungles Casino" desired. Pork and Beans, The Mule Walk, and Cuttin' Out all have forms derived from the multistrain structure of ragtime. However, in Handful of Keys, Waller's use of the thirty-two-bar form demonstrates how stride pianists, many of whom worked in musical theater, were also interested in popular song forms. Finally, all four recordings analyzed in this chapter demonstrate that stride truly is a synthesis of three musical traditions: ragtime, the blues, and the ring shout. 


\section{Chapter Five}

\section{Conclusions}

Stride is more than a jazz piano style. It was an important form of entertainment that revolved around one person capable of playing virtuosic music, generating crowds, accompanying dancers and vocalists, and creating a good time atmosphere. The best stride entertainers had flair and the capability to "wow" folks night after night.

Stride was competitive. On any given night an uninvited pianist could appear at a rent party or Harlem club ready to challenge the hired performer for the evening. To dazzle audiences and avoid defeat from rival pianists stride musicians had to play with accuracy and flamboyance. The competitive spirit of stride led to the development of flashy musical licks known as "tricks" and virtuosic compositions. The best stride pianists could also play in any key and read music fluently.

The elite performers and entertainers of stride's heyday were Roberts, Johnson, Smith, and Waller. Roberts' work in theater during his youth paired with his incredible piano talent made him one of the best entertainers in New York during the 1910s. Johnson was referred to by his contemporaries as the king of stride. His Carolina Shout was the ultimate test piece for any pianists wanting to establish themselves in Harlem's stride circuit. Smith had flair and an intimidating personality. He raised the standard for how stride entertainers should dress, act, and perform. Finally, Waller was the most popular of all stride entertainers. He transformed the stride genre by integrating aspects of popular music, such as melody and form, into his works.

Stride synthesizes elements of ragtime, the blues, and dance music. One of the most influential black dances on stride was the ring shout. Some of the musical practices found in the ring that stride composers incorporated include call-and-response devices, complex 
syncopations, an inevitable steady pulse, and off-beat melodies. Also, the excitement and energy of the shout was imitated in stride by the use of fast tempos. Three of the pieces analyzed in chapter four demonstrated the influence of the ring on stride. Pork and Beans and Handful of Keys have strains that utilized call-and-response and Cuttin' Out has several passages of complex syncopation.

The melodic style in stride was also largely influenced by dance music. Many stride pianists in their early careers worked for dance clubs in the "Tenderloin" section of Manhattan. The patrons of these dance clubs, such as "The Jungles Casino," loved when pianists played melodies that were based on short and rhythmically repetitive ideas. In stride, these melodic ideas are classified as riffs and grooves. A riff is a two- or four-bar thematic idea that undergoes some sort of alteration as the strain progresses. Either the pitch content is preserved while the rhythm is modified, or the pitch content is modified and the rhythm is preserved. A short thematic idea that is repeated continuously with no alteration to the rhythm or pitches is a groove. All four pieces analyzed in chapter four have melodies that are based on riffs and grooves.

Stride players adopted many of the musical characteristics associated with ragtime, such as formal conventions and the left hand accompaniment style, into their compositions. Stride compositions often are based on three to four independent sixteen-bar themes called strains. There are three different ways that stride composers usually arranged strains: "Typical Strain Arrangement No. 1" (AABBACCC), “Typical Strain Arrangement No. 2” (AABBCCDD), and “Typical Strain Arrangement No. 3" (AABBCCA). Additionally, most strain arrangements follow a predictable harmonic scheme. When stride compositions are in major modes, the first (A) and second (B) strains are in tonic, and the third (C) and fourth (D) strains, also known as the 
trios, are in subdominant. When a stride composition is in a minor mode, the first (A) strain is in tonic, the second (B) strain is in the relative major, and the third (C) and fourth (D) strains are in the subdominant of the relative major.

Pork and Beans and The Mule Walk have structures closely related to "Typical Strain Arrangement No. 1." The structure of Cuttin' Out is unusual in that the "A" strain repeats many times, the "A" strain frequently recurs after the trio sections, and two of the trio strains, "C" and "D", remain in the same key as the "A" and "B" strains. Finally, Handful of Keys has the most interesting structure of the four pieces analyzed. Instead of using the rigid sixteen-bar strain formula associated with ragtime, Waller integrates one of the most popular song forms of the mid-1920s, the thirty-two-bar form, into this composition.

The most common left hand accompaniment used in a stride is the "omm-pah" - a regular alteration of low bass notes or octaves on strong beats and mid-range chords on weak beats. Stride players were notorious for playing "omm-pah" patterns that had large leaps or "strides" between strong and weak beats. Some of the other left hand devices that stride players used included walking bass lines, reversed "omm-pah" (where the low bass notes occur on the weak beats and the mid-range chords on strong beats), backward tenths, boogie-woogie patterns, and Latin and Spanish rhythms such as the tango and habanera. The Mule Walk, Cuttin' Out, and Handful of Keys all have a variety of left hand accompanimental devices. However, compared to other pieces analyzed in chapter four, the left hand accompaniment in Pork and Beans is simpler and more closely related to the ragtime style.

To a lesser extent than ragtime and dance music, the blues was influential in the development of stride. From the blues, stride players incorporated crushed notes, blues notes, and occasionally used twelve-bar blues progressions in lieu of sixteen-bar strains. James P. 
Johnson's Reverie is one of the best examples of a stride composition that features musical elements of the blues.

This research document was written with the intention of explaining how the culture and black entertainment interests of Manhattan fostered the development of stride and to provide insight into the musical components that define the stride style. In investigating the culture of Manhattan from c.1900 to c. 1940, and the lives and piano music of Roberts, Johnson, Smith, and Waller, four things became apparent.

First, although stride and ragtime have similarities, such as formal structures and the use of "omm-pah," these two styles greatly contrast from each other in several ways. In general ragtime is played slowly, lacks virtuosity, eighth-note rhythms are played evenly, accompaniment patterns are almost exclusively based on the "omm-pah," and melodies are short and jerky. In contrast, stride is often played fast, requires virtuosity, eighth-note rhythms are swung, a variety of accompaniment patterns such as "omm-pah" and walking bass lines are used, and melodies are smooth and fluid.

Second, the significant increase in Manhattan's black population during the early decades of the 1900s contributed to the development of stride. Southern blacks looking for a better way of life migrated in large numbers to northern cities during the late nineteenth century, continuing through the 1920s and 1930s. Late ragtime pianists became interested in the dance music that these southern migrants brought with them. By the 1910s, ragtime pianists began incorporating what they heard and saw from southern black dances, such as the ring shout, into their music thus beginning a new style of jazz piano - stride.

Third, due to the improvisational and competitive nature of the idiom, stride pianists rarely played a tune the same way. This is evident when listening to and comparing early piano 
recordings to later recordings of the same piece. For example, in Chapter Four it was apparent that Donald Lambert had greatly altered the structure of Luckey's 1913 publication of Pork and Beans by adding a vamp and extra strains.

Finally, the lives and careers of Roberts, Johnson, Smith, and Waller have several common themes. All four of these pianists were largely self-taught, learning to play by listening to, absorbing, and emulating the music they heard performed by ragtime pianists at Manhattan clubs and bars. Johnson specifically mentioned learning to play the backward tenth by listening and watching the early stride pianist Fred Bryant. Fortunately for these four pianists, their friends and mentors, specifically Ernest Green, encouraged them to pursue formal musical training. Classically trained musicians, such as Bruto Giannini, taught several of the significant stride pianists of the 1920s theory, note reading, and proper piano technique.

Another common theme among these four pianists is that they all worked in musical theater. Through work in musical theater these pianists made professional connections and learned how to be well-rounded entertainers. Waller's interest in musical theater and popular musical idioms is apparent in many of his compositions. For example, in Handful of Keys Waller incorporated one of the most popular song forms of the 1920 s - the thirty-two bar form.

A final common theme among these four musicians is that they had interest in writing extended compositions that incorporated jazz and classical elements. However, these works generally did not receive favorable reviews from audiences and conductors. Only sporadic performances of these extended compositions, such as Johnson's Yamekraw, occur today.

Whether in live performance or on recording, stride still sounds as fresh and exciting today as it did in the early- and mid-twentieth century. The virtuosity and captivating rhythms make it one of the most exciting forms of jazz and a landmark in American music. 


\section{BIBLIOGRAPHY}

Aloisio, Gerald S. "A Historical Summary of Major Musical Developments in American Jazz from the end of World War I to the Beginning of World War II." DMA diss., University of Cincinnati, 1995.

Barnhart, Bruce. "CAROLINA SHOUT James P. Johnson and the Performance of Temporality." Callaloo (Summer 2010): 841-856.

Bechet, Sidney. "Sidney Bechet." in Reading Jazz: A Gathering of Autobiography, Reportage and Criticism from 1919 to Now, ed. Robert Gottlieb. New York: Pantheon, 1996.

Berendt, Joachim E. The Jazz Book: From Ragtime to Fusion and Beyond. Translated by Dan Morgenstern and Tim Nevill. New York: Lawrence Hill Books, 1992.

Berlin, Edward A. "Ragtime." In Grove Music Online. Oxford Music Online, http://www.oxfordmusiconline.com/subscriber/article/grove/music/22825 (accessed February 29, 2012).

. "Ragtime in Old New York." NYC Jazz (June 1980): 22.

. Reflections and Research on Ragtime. Brooklyn: Institute for Studies in American Music, 1987.

Blesh, Rudi and Harriet Janis. They All Played Ragtime: The True Story of an American Music. New York: Alfred A. Knopf, 1950.

Brown, Scott E. and Robert Hilbert. James P. Johnson: A Case of Mistaken Identity. Metuchen, NJ: The Scarecrow Press and the Institute of Jazz Studies, Rutgers University, 1986.

Crow, Bill. Jazz Anecdotes: Second Time Around. Oxford: Oxford University Press, 2005.

Davin, Tom. “Conversations with James. P. Johnson.” In Ragtime: Its History, Composers, and Music, ed. John Edward Hasse. New York: Schirmer, 1985.

. “Conversations with James P. Johnson.” The Jazz Review (July 1959): 12.

Dobbins, Bill, and Barry Kernfeld. "Smith, Willie 'the Lion'." In The New Grove Dictionary of Jazz, 2nd ed., edited by Barry Kernfeld. Grove Music Online. Oxford Music Online, http://www.oxfordmusiconline.com/subscriber/article/grove/music/J418400 (accessed May 15, 2012).

Dicaire, David. Jazz Musicians of the Early Years, to 1945. Jefferson, NC: McFarland, 2003.

Floyd Jr., Samuel A. "Ring Shout! Literary Studies, Historical Studies, and Black Music Inquiry.” Black Music Research Journal. (Fall 1991): 265-287. 
Francis, Henry. “Musical Aspects of Stride Piano.” Storyville (August-September 1972): 213.

Gioia, Ted. The History of Jazz. New York: Oxford University Press, 1997.

Harrison, Max. "James P. Johnson.” In Reading Jazz: A Gathering of Autobiography, Reportage and Criticism from 1919 to Now, ed. Robert Gottlieb. New York: Pantheon, 1996.

Hentoff, Nat. "Garvin Bushell and the New York Scene.” The Jazz Review (February 1959): 10.

Jasen, David A., and Trebor Jay Tichenor. Rags and Ragtime: A Musical History. New York: Seabury, 1978. ., and Gene Jones. Black Bottom Stomp: Eight Masters of Ragtime and Early Jazz. New York: Routledge, 2002.

Martin, Henry. "Balancing Composition and Improvisation in James P. Johnson's Carolina Shout." Journal of Music Theory (Fall 2005): 277-299. . "Pianists of the 1920s and 1930s." In The Oxford Companion to Jazz, ed. Bill Kirchner. New York: Oxford University Press, 2000.

Marcorelles, Paul. Donald Lambert: Fifteen Solos for Piano. Blue Black Jazz, 2009. .Willie "the Lion: Smith: Sixteen Solos for Piano. Blue Black Jazz, 2009.

Montgomery, Michael, Trebor Jay Tichenor, and John Edward Hasse. "Ragtime on piano rolls." In Ragtime: Its History, Composers, and Music, ed. John Edward Hasse, New York: Schirmer, 1985.

Newberger, Eli. "The Development of New Orleans and Stride Piano Styles." Journal of Jazz Studies. (Spring/Summer 1977): 43-71.

Owens, Thomas. "Forms." The New Grove Dictionary of Jazz, 2nd ed. In Grove Music Online. Oxford Music Online. Oxford University Press, http://www.oxfordmusiconline.com/subscriber/article/grove/music/J154400 (accessed November 13, 2012).

Peretti, Burton W. Jazz in American Culture. Chicago: Ivan R. Dee, 1997.

Posnak, Paul. Thomas "Fats" Waller: The Great Solos, 1929-1937. Milwaukee: Hal Leonard, 1998.

Priestley, Brian. "Ragtime, Blues, Jazz and Popular Music." In The Cambridge Companion to the Piano, ed. David E. Rowland. New York: Cambridge University Press, 1988. 
Riis, Thomas L. "New York Roots: Black Broadway, James Reese Europe, Early Pianists.” In The Oxford Companion to Jazz, ed. Kirchner, Bill. New York: Oxford University Press, 2000.

Robinson, J. Bradford. "Stride." In Grove Music Online. Oxford Music Online, http://www.oxfordmusiconline.com/subscriber/article/grove/music/26955 (accessed February 29, 2012).

Rouder, Willa. "Johnson, James P." In Grove Music Online. Oxford Music Online, http://www.oxfordmusiconline.com/subscriber/article/grove/music/14409 (accessed May 15, 2012).

Schuller, Gunther. Early Jazz: Its Roots and Musical Development. New York: Oxford University Press, 1986.

Scivales, Riccardo. Harlem Stride Piano Solos: 26 Classic Solos by The Greatest Jazz Pianists of The Swing Era. Bedford Hills, NY: Ekay Music, 1995.

Shipton, Alyn. A New History of Jazz. New York: Continuum, 2007. and Bill Dobbins. "Waller, Fats." In Grove Music Online. Oxford Music Online, http://www.oxfordmusiconline.com/subscriber/article/grove/music/48692 (accessed May 15, 2012).

Smith, Willie "the Lion." "Willie 'the Lion' Smith.” In Reading Jazz: A Gathering of Autobiography, Reportage and Criticism from 1919 to Now, ed. Robert Gottlieb. New York: Pantheon, 1996.

Stewart, Rex. "The Cutting Sessions." In Reading Jazz: A Gathering of Autobiography, Reportage and Criticism from 1919 to Now, ed. Robert Gottlieb. New York: Pantheon, 1996.

Taylor, J. R., and Barry Kernfeld. "Roberts, Luckey." In The New Grove Dictionary of Jazz, 2nd ed., edited by Barry Kernfeld. Grove Music Online. Oxford Music Online, http://www.oxfordmusiconline.com/subscriber/article/grove/music/J381800 (accessed May 15, 2012).

Taylor, William. "Jazz Piano: History and Development: A New Perspective for Educators." EdD diss., University of Michigan, 1975.

Vinding, Terkild, and John L. Fell. Stride! Fats, Jimmy, Lion, Lamb, and all the other Ticklers. Lanham, MD: Scarecrow, 1999.

Waldo, Terry. This is Ragtime. New York: Hawthorn, 1976.

Waller, Maurice, and Anthony Calabrese. Fats Waller. New York: Schirmer, 1977. 
Wilder, Alec. American Popular Song: the Great Innovators 1900-1950. New York: Oxford University Press, 1972, 56.

Williams, Martin, ed. Jazz Panorama. New York: Collier Books/Collier-Macmillan, 1964.

Wilson, John S. "The Cutting Sessions.” In Reading Jazz: A Gathering of Autobiography, Reportage and Criticism from 1919 to Now, ed. Robert Gottlieb. New York: Pantheon, 1996. 